Revista de Economia

Empresas e

Empreendedores

na CPLP

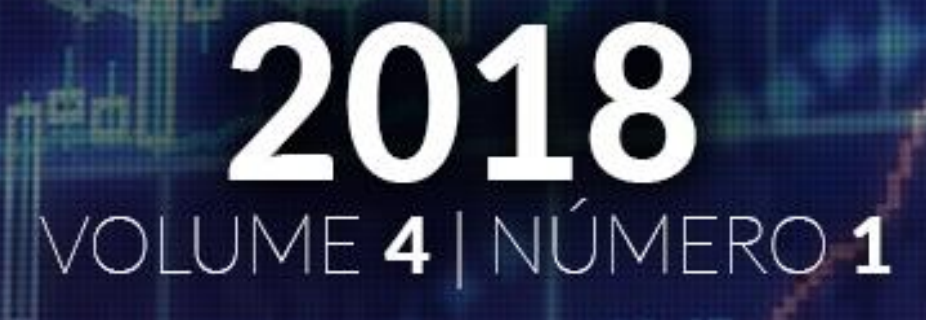

ISSN (PRINT): 2183-380X ISSN (ONLINE): 2183-720I

pontěditora 


\section{Editor-chefe}

Doutora Ana Maria Alves Bandeira, Instituto Politécnico do Porto, Instituto Superior de Contabilidade e Administração do Porto (ISCAP.PP), CEPESE, CEOS.PP, Portugal

\section{Editor PT}

Doutor Carlos Machado Santos, UTAD, Portugal

\section{Editor Adjunto}

Doutora Amélia Cristina Ferreira-da-Silva, Instituto Politécnico do Porto, Instituto Superior de Contabilidade e Administração do Porto, CEPESE, CECEJ, Portugal

\section{Editor AO}

Doutorando Benjamim M'Bakassy, UBI, Portugal

\section{Editor BR}

Doutora Kimberly Marie Jones, Associação Educativa do Brasil (SOEBRAS), Brasil

\section{Editor TP}

Agio Pereira, Ministro de Estado e da Presidência do Conselho de Ministros VI Governo Constitucional, Timor-Leste

\section{Conselho Científico}

Doutora Amélia Cristina Ferreira-da-Silva, Instituto Politécnico do Porto, Instituto Superior de Contabilidade e Administração do Porto, CEPESE, CECEJ.

Professora Doutora Ana Maria Paiva, Universidade Aberta - CEPESE - Centro de Estudos da População, Economia e Sociedade, Portugal

Doutora Anabela Martins Silva, Universidade do Minho, Portugal

Doutora Antonieta Maria Lima, ISVOUGA, Portugal

Doutor Carlos Machado Santos, UTAD, Portugal

Doutor Eduardo Manuel de Almeida Leite, Funorte; SOEBRAS, Brasil

Doutor Fábio Augusto Martins, Uniaraxá - Centro Universitário do Planalto de Araxá, Brasil

Doutor Fernando Jorge Rodrigues, Instituto Politécnico do Cávado e do Ave Escola Superior de Gestão, Portugal

Doutor Fernando Oliveira Tavares, Universidade Portucalense Infante D. Henrique, Portugal

Doutora Helena Santos de Oliveira, Universidade de Vigo; Professora Adjunta no ISCAP/IPP, Portugal 


\section{pontěditora}

Professor Doutor Herlandí de Souza Andrade, FATEC Guaratinguetá e Anhanguera

Doutor José Manuel Teixeira Pereira, Instituto Politécnico do Cávado e do Ave, Portugal

Doutora Kimberly Marie Jones, Associação Educativa do Brasil (SOEBRAS), Brasil

Doutor Maximiliano E Korstanje, Universidad de Palermo, Argentina - Visiting Fellow at CERS Universidad de Leeds UK, Argentina

Doutor Nelson Duarte, Escola Superior de Tecnologia e Gestão - P.PORTO

Doutor Óscar Afonso, Universidade do Porto, Faculdade de Economia, Portugal

Doutor Patrício Batsîkama Mampuya Cipriano, Universidade Agostinho Neto, Luanda, Angola

Doutora Raquel Susana Pereira, Instituto Politécnico do Porto CEOS.PP - Centro de Estudos Organizacionais e Sociais do P.Porto, Portugal

Doutora Rossana Andreia Santos, ISAL Madeira, Portugal

Doutora Simone Valéria Dias Souto, Brasil

\section{Conselho Editorial}

Mestre Árlen Almeida Duarte de Sousa, Faculdades Integradas do Norte de Minas FUNORTE, Brasil

Mestre Andrey George Souza, Faculdades Unidas do Norte de Minas - FUNORTE Universidade Estadual de Montes Claros - UNIMONTES, Prefeitura Municipal de Montes Claros

Dr. Fabrizio Bon Vecchio, Universidade Federal do Rio Grande do Sul - FUNDAÇÃO GETULIO VARGAS UTAD, Brasil

Mestre Frederico Bida Oliveira, Faculdades Integradas do Norte de Minas, Brasil

Mestre Gisela Filipa Ferreira, Universidade de Trás os Montes e Alto Douro, Portugal

Mestre Igor Raineh Cruz, Faculdades Integradas do Norte de Minas - Funorte, Brasil

Mestre Leonardo Augusto Couto Finelli, Faculdades Unidas do Norte de Minas - FUNORTE Faculdades de Saúde Ibituruna - FASI, Brasil

Mestre Maria Lina de Santana Freitas, Faculdade Promove de Janaúba, Brasil

Mestre Rui Miguel Pinho, Universidade Federal Rio de Janeiro - UFRJ, Brasil

Mestre Thiago Henrique Alves de Souza, Faculdades Integradas do Norte de Minas - Funorte, Brasil

Mestre Wellington Danilo Soares, Programa de Pós-Graduação em Ciências da Saúde PPGCS/Unimontes, Brasil

Mestre Wiliam Toneli Da Silva, FUNORTE / SOEBRAS, Brasil

$\mathrm{e}^{3}$ - Revista de Economia, Empresas e Empreendedores na CPLP | Volume 4 | Número 1 


\section{Chefe de Redação e Edição}

Ana Leite, Universidade de Aveiro, Portugal

\section{Redator PT}

Mestre Eduarda Pinto, FADEUP, Portugal

\section{Redator BR}

Mayze Liduario Vargas, ASSOCIAÇÃO EDUCATIVA DO BRASIL - SOEBRAS

\section{Executivos}

Dr. Teófilo Sousa Fonseca, Moçambique, Timor-Leste, Espanha, Angola, Portugal.

\section{Ficha Técnica}

ISSN (print): 2183-380X

ISSN (online): 2183-7201

Periodicidade: Semestral (janeiro, julho)

Propriedade/Editora: Ponte Editora, Sociedade Unipessoal, Lda.

\section{Contactos}

Telefone: 291723010

E-mail: geral@ponteditora.org

\section{Endereço para correspondência:}

$\mathrm{e}^{3}$ - Revista de Economia, Empresas e Empreendedores na CPLP.

Ponte Editora, Sociedade Unipessoal, Lda.

Startup Madeira - Sala 3

Campus da Penteada

9020-105 Funchal, Madeira 


\section{Estatuto Editorial}

I - A $\mathbf{e}^{\mathbf{3}}$ - Revista de Economia, Empresas e Empreendedores na CPLP, conhecida também pelas formas abreviadas de $\mathbf{e}^{\mathbf{3}}$ ou Revista $\mathbf{e}^{\mathbf{3}}$, é uma publicação periódica gerida pela Ponteditora.

II - Sob o lema de Fernando Pessoa: "A minha pátria é a língua portuguesa", a $\mathbf{e}^{\mathbf{3}}$ é uma publicação para a difusão da ciência em Português, vocacionada para a lusofonia e para os países da CPLP.

III - A linha editorial da $\mathbf{e}^{\mathbf{3}}$ centra-se na área dos negócios, transversal a disciplinas como a economia, gestão, contabilidade, finanças, recursos humanos, marketing, entre outras.

IV - A $\mathbf{e}^{\mathbf{3}}$ tem por missão fomentar a ciência em Português para o setor dos negócios, como forma de estimular o empreendedorismo e os negócios entre as economias dos países da CPLP.

$\mathrm{V}-\mathrm{A} \mathbf{e}^{\mathbf{3}}$ é editada semestralmente, em papel, em Portugal e, quando se justificar, na CPLP, e disseminada no resto do mundo através da internet.

$\mathrm{VI}-\mathrm{A} \mathbf{e}^{\mathbf{3}}$ terá aproximadamente 80 a 100 páginas de formato A4 e uma tiragem em papel inferior a 1.000 exemplares.

VII - A $\mathbf{e}^{\mathbf{3}}$ destina-se a professores, investigadores, estudantes e profissionais, nacionais ou estrangeiros, desde que com interesses empresariais na CPLP.

VIII - $\mathrm{A} \mathbf{e}^{\mathbf{3}}$ apresenta um corpo editorial técnico e científico, aberto a académicos, investigadores, profissionais e executivos de organizações e empresas relacionadas com a atividade empresarial na CPLP, tais como: CEOS, CFO, entre outros.

IX - $\mathrm{A} \mathbf{e}^{3}$ publica artigos do tipo: original, de revisão e de opinião.

$\mathrm{X}-\mathrm{A} \mathbf{e}^{\mathbf{3}}$ publica em Português, podendo excecionalmente apresentar artigos noutra língua, desde que se trate de uma língua reconhecida internacionalmente no meio académico e em negócios, como por exemplo: inglês.

$\mathrm{XI}-\mathrm{A} \mathbf{e}^{\mathbf{3}}$ pretende promover o intercâmbio de ideias, experiências e projetos entre os autores, empreendedores e o mercado empresarial, contribuindo para a reflexão dos negócios na CPLP e para a sua ligação com a sociedade. 


\section{Índice}

\section{Editorial}

Editorial

Ana Maria Alves Bandeira

A revalorização do imobiliário e o seu impacto nas Demonstrações Financeiras

Real Estate appreciation and its impact in Financial Demonstrations

Maria da Conceição Carapinha; Fernando Tavares; Antonieta Maria Lima.

Pesquisa de Clima Organizacional: um estudo de caso

Research of Organizational Climate: a case study

Mayara Alexandre Costa

Decisões de financiamento bancário por parte da banca angolana: o caso do Banco de Poupança e Crédito

Bank financing decisions by Angolan banks: the case study of Banco de Poupança e Crédito

Benedito Manuel; Fernando Oliveira Tavares; Luís Pacheco.

Planeamento estratégico aplicado à carreira musical

Strategic plan applied to the musical career

Lucas Caldoncelli Gomes; Leila Vaz da Silva; Daniela Ferreira.

Serviço de pós-venda e fidelização de clientes: estudo de caso numa farmácia magistral

Post-sales service and customer loyalty: case study in a mastercard pharmacy

Sayure Brito Santos 


\section{Editorial}

\section{Editorial}

Diretora da $\mathrm{e}^{3}$, Ana Maria Alves Bandeira ${ }^{1}$

${ }^{1}$ E-mail: bandeira@iscap.ipp.pt

Instituto Superior de Contabilidade e Administração do Politécnico do Porto (ISCAP.PP)

\section{A Revista de Economia, Empresas e Empreendedores na CPLP agora no seu quarto} número continua a prosseguir a sua política de trabalhar no sentido de proporcionar um fórum para a para a difusão de ciência em português. Estou ligada a esta revista desde o seu início, estive sempre presente ao longo do seu percurso e, por isso, quando me lançaram o desafio para assumir funções de Editora Chefe aceitei com muita satisfação, pois acredito no potencial desta revista e na sua importância enquanto elemento precioso na divulgação de ciência em português. A revista pretende continuar a acolher todo o tipo de investigação de qualidade de forma aberta e a trabalhar no sentido de assegurar aos autores todo o apoio necessário para as suas publicações de qualidade, procurando proporcionar-lhes comentários construtivos por parte dos revisores.

Para este número destaca-se a elevada participação dos autores, tendo sido aceites para publicação cinco artigos e outros encontram-se em curso. Trata-se de um número onde são abordados vários temas das ciências empresariais de interesse relevante, tais como a Contabilidade, as Ciências da Administração, as Finanças, a Gestão Estratégia e o Marketing. Temas estes que têm merecido a atenção por parte de académicos mas também de profissionais de reconhecido prestígio internacional.

Assim, aborda-se o impacto da revalorização dos bens imóveis e o seu impacto nas demonstrações financeiras e nos indicadores económicos e financeiros empresariais, tendo por base o normativo do Justo Valor. Trata-se de um estudo que permite um amplo e detalhado conhecimento sobre a revalorização dos imobiliários onde se pode verificar que os ajustes de revalorização provenientes de aumentos de ativos imobiliários têm impactos a vários níveis, mais concretamente nos impostos sobre o rendimento, na avaliação do desempenho dos gestores e também nos indicadores de solvabilidades, de autonomia financeira e de endividamento. $\mathrm{O}$ artigo seguinte assenta 


\section{pontěditora}

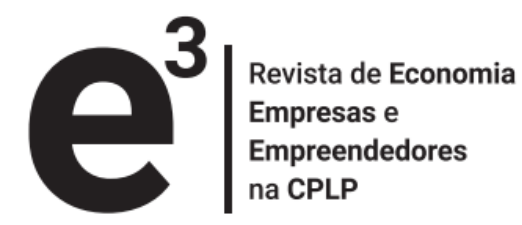

numa pesquisa de Clima Organizacional, neste estudo é evidenciada a importância do capital humano enquanto instrumento de gestão e parte da sua estratégia no alcance dos objetivos organizacionais. Esta pesquisa aborda os fatores que têm influência no clima organizacional e como este pode interferir nos comportamentos e na motivação pessoal e profissional.

As decisões de financiamento bancário por parte da banca angolana é o tema abordado no artigo que se segue, onde é realizado um estudo ao Banco de Poupança e Crédito. Esta investigação é um sinal de alerta para a necessidade de tornar mais transparente e rigoroso o processo de seleção, análise, avaliação e aprovação com vista a poderem ser tomadas as melhores decisões de financiamento possíveis. A gestão estratégica é abordada no artigo intitulado "Planeamento estratégico aplicado à carreira musical", onde são apresentadas as principais etapas para o desenvolvimento de um planeamento estratégico de um empreendimento musical. Mostra ainda a gestão estratégica enquanto ferramenta fundamental para alavancar uma carreira artística. Este estudo apresenta ainda um plano estratégico de modo a ser aplicado no desenvolvimento de uma carreira musical independente.

$\mathrm{O}$ artigo que se segue tem o seu enquadramento na área temática do Marketing e aborda a questão do "Serviço pós-venda e fidelização". Trata-se de um tema de extrema relevância para a sustentabilidade de qualquer organização uma vez que, como refere o estudo, o serviço de pós-venda pode ser considerado um diferencial competitivo capaz de ajudar as empresas na fidelização dos seus clientes.

Por fim, o Conselho Editorial agradece a todos os que participaram na construção da $\mathbf{e}^{\mathbf{3}}$ e na publicação de mais este volume, esperando continuar a contar com todos e, sobretudo, com os autores e revisores para que todos juntos possamos melhorar cada vez mais a Revista de Economia, Empresas e Empreendedores na CPLP.

\section{(cc) BY-NC-SA}

O trabalho $\mathrm{e}^{3}$ - Revista de Economia, Empresas e Empreendedores na CPLP está licenciado com uma Licença Creative Commons - Atribuição-NãoComercial-Compartilhalgual 4.0 Internacional.

$\mathrm{e}^{3}$ - Revista de Economia, Empresas e Empreendedores na CPLP | Volume 4 | Número 1 


\title{
A revalorização do imobiliário e o seu impacto nas Demonstrações Financeiras
}

\author{
Real Estate appreciation and its impact in Financial Demonstrations
}

Maria da Conceição Carapinha ${ }^{1}$; Fernando Tavares ${ }^{2}$; Antonieta Maria Lima ${ }^{3}$.

\author{
${ }^{1}$ E-mail: mcc@ecco.com \\ Universidade Portucalense Infante D. Henrique \\ 2 E-mail: ftavares@upt.pt \\ Universidade Portucalense Infante D. Henrique \\ ${ }^{2}$ E-mail: antonieta_sousa_lima@hotmail.com \\ Universidade Portucalense Infante D. Henrique
}

Resumo: O objetivo deste artigo é estudar o impacto nas Demonstrações Financeiras e nos indicadores económicos e financeiros da revalorização de ativos imobiliários, tendo por base a Diretriz do Justo Valor. A metodologia utilizada é o estudo de experimentação. Envolve um estudo profundo e exaustivo, a fim de permitir um amplo e detalhado conhecimento sobre o impacto nas Demonstrações Financeiras e nos indicadores económicos e financeiros empresariais. Trata-se de uma pesquisa experimental. É efetuada uma revisão da literatura sobre o conceito de justo valor, de ativos fixos tangíveis e de propriedades de investimento, e sobre a análise económica e financeira das empresas. Verificou-se que os ajustes de revalorização provenientes de aumentos de ativos imobiliários têm impactos a nível das demonstrações financeiras, a nível dos impostos sobre o rendimento, a nível da avaliação do desempenho dos gestores (de forma negativa) e a nível dos indicadores de solvabilidades, de autonomia financeira e de endividamento.

Palavras-chave: Justo Valor; Ativos Imobiliários; Avaliação Imobiliária; Revalorização Imobiliária; Análise Financeira.

\begin{abstract}
The aim of this paper is to study the impact in Financial Demonstrations and in economic and financial indicators of the real estate assets' appreciation, starting from the Guideline of the Fair Value. The used methodology is the case study. It involves a profound and exhaustive study, in order to allow the possession of a wide and thorough knowledge on the impact in Financial Demonstrations and in economic and financial indicators. This is an experimental research. A revision of the literature about the concept of fair trade, tangible fixed assets and investment properties is performed, as well as an economic and financial analysis of the companies. It has been found that the appreciation adjustments from real estate assets have impact on financial demonstrations, income taxes, managers' performance evaluation (in a negative way), solvency indicators, financial autonomy and debt.
\end{abstract}

Keywords: Fair Trade; Real Estate Assets; Real Estate Appraisal; Real Estate Appreciation; Financial Analysis. 


\section{pontěditora}

\section{1 - INTRODUÇÃO}

A Avaliação Imobiliária é uma técnica que pretende estimar o valor que os bens imobiliários apresentam, quanto é que de facto valem, numa determinada data, com determinadas características e dentro de uma determinada conjuntura de mercado.

Estas avaliações podem ter como finalidade uma grande variedade de situações, que podem passar por: partilha dos bens de uma herança; a compra ou venda de imóveis; o financiamento bancário para compra ou construção de um imóvel; o estudo económico e financeiro de um projeto de investimento; o cálculo de uma indemnização por expropriação; a determinação do valor para efeitos fiscais e, por último, a determinação do correspondente valor de mercado aqui entendido como "Justo Valor". E é sobre este último aspeto que incide este trabalho, ou seja, a realização de uma avaliação imobiliária com o objetivo de determinar se as alterações de Justo Valor de certos ativos têm impacto nas Demonstrações Financeiras (DF's).

O Justo Valor é um tema que está presente no dia a dia de quem gere uma organização empresarial, pois, como explica Iudícibus e Martins (2007), ao colocarmos em contraposição o critério do justo valor com o do custo histórico teremos, obviamente, de concluir que o primeiro é objetivo, sendo o último subjetivo. Ou seja, a relevação contabilística ao "Justo Valor" terá de ser aplicada com precaução (apelo ao princípio contabilístico "Da Prudência"), sob pena de afetarmos a contabilidade e as demonstrações financeiras com valores subjetivos, o que não facilita a decisão dos stakeholders.

A Norma Internacional de Contabilidade (NIC) 39 estabelece algumas regras fundamentais para aplicação do "Justo Valor", referindo designadamente que deverá ter como referência um preço de mercado fiável ou, não sendo possível, por aplicação de critérios de valorimetria aproximados ao valor de mercado.

Este trabalho começa por apresentar uma revisão de literatura, focando os aspetos essenciais da avaliação imobiliária, e a perspetiva contabilística e financeira desta avaliação. Seguidamente, é apresentado um estudo de experimentação, baseado em 


\section{pontěditora}

dados reais, que permitirá quantificar o impacto de uma avaliação imobiliária nas DF's. Este trabalho termina com as conclusões gerais.

\section{2 - A AVALIAÇÃO IMOBILIÁRIA}

Para Pardal e Lobo (2011) a avaliação, por natureza, tem um caráter previsional e crítico, é um exercício de antecipação de um contexto de permanente mudança. A tarefa de avaliar é tanto mais segura e assertiva, quanto mais fluido e informado for o mercado.

Já quanto ao mercado, um dos fatores que irá influenciar a própria avaliação, tal como Pardal e Lobo (2011) referem, pode apontar-se as seguintes características específicas do mercado imobiliário:

- Todos os prédios são singulares, sendo impossível haver dois prédios absolutamente iguais;

- Há uma elevada probabilidade de um número reduzido de compradores e de vendedores chamarem a si o poder e influenciar os preços, exercendo um controlo impróprio, tanto ao nível da oferta como da procura, se não houver uma intervenção reguladora em sede de políticas de solos;

- Quando há desequilíbrios entre a oferta e a procura, o reequilíbrio, principalmente quando depende de um aumento da oferta, é extremamente moroso, podendo passar-se anos entre a decisão de construir e a disponibilidade da construção no mercado;

- A oferta e a procura não têm uma relação formalmente estruturada, embora o setor da mediação tenha contribuído nos últimos anos de forma positiva para tornar estas relações mais transparentes e informadas;

- Enquanto investimento, os imóveis apresentam falta de liquidez; o solo é um produto imperecível e as construções são um produto durável e sujeito a uma depreciação muito lenta; 


\section{pontěditora}

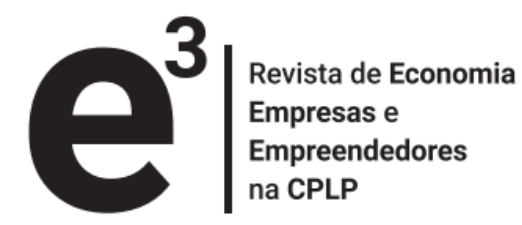

- Os imóveis estão sujeitos a diversos encargos tributários, que agravam os custos de transação, quer para o comprador, quer para o vendedor. Não é saudável que o regime fiscal dificulte e penalize a mobilidade das famílias e das empresas.

Em suma, uma avaliação surge da conjugação de diferentes fatores e de condições específicas de mercado, dando então origem a um valor que será utilizado de acordo com o objetivo para o qual foi solicitado. No entanto, e estando perante a existência de múltiplos fatores, pode-se facilmente constatar que as avaliações acarretam subjetividade e complexidade, e até poder-se-á mesmo dizer de juízos de valor, o que decerto dificultará qualquer tomada de decisão.

Tavares, Pereira e Moreira (2009) são de opinião que avaliar um imóvel consiste em associar uma quantidade de dinheiro a um bem ou direito em função das suas qualidades e como consequência de determinadas condições de mercado. Para os autores a avaliação imobiliária é uma atividade multidisciplinar que requer um amplo leque de conhecimentos. Os profissionais imobiliários pela sua proximidade ao mercado têm um maior conhecimento sobre o comportamento da oferta e da procura, dos preços, das tendências e das flutuações do mercado.

Assim, o objetivo de uma avaliação imobiliária será o de estimar o valor de mercado, com a finalidade de obter um preço, que será pago por um comprador interessado, numa compra não forçada, a um vendedor, também este interessado e não forçado a vender. Desta forma, ambos terão de ter plenos conhecimentos das condições do mercado como também da própria utilidade do imóvel transacionado. Está-se então perante uma transação normal de compra e venda.

No entanto, existem muitas outras situações em que os interessados não são os normais compradores/vendedores e desta forma fora do âmbito de uma normal compra/venda, como se pode ver abaixo na Figura 1. 
Figura 1 - Interessados nas Avaliações

\section{Interessados}

Empresas Imobiliárias

Instituições Públicas

Instituições Bancárias

Seguradoras

Direção Geral dos Impostos

O Tecido Empresarial e Outros Sujeitos

\section{Finalidade}

Transferências de Propriedade.

Indemnizações (que se querem justas) em caso de expropriações; Registo Predial "Cadastral".

Concessão de Financiamentos e Créditos.

Indemnizações (que se querem justas) em caso de acidentes.

Cálculo de Impostos sobre Imóveis.

Justo Valor para arrendamento; Oportunidades de Investimento; Justo Valor para efeitos contabilísticos; Fusões e Cisões.

Fonte: Elaborada pelos autores.

Podemos então concluir que, dependendo dos interessados, as avaliações podem ter finalidades completamente diferentes. Por isso, diferentes valores podem ter de ser obtidos através de tipos e métodos de avaliação completamente diferentes.

\section{1 - Os ativos imobiliários na perspetiva contabilística e a análise financeira}

Os ativos imobiliários, numa perspetiva empresarial e consequentemente numa perspetiva contabilística, são todos aqueles que estão diretamente relacionados com a própria atividade da empresa, podendo estes ser: terrenos; unidades fabris; armazéns; estabelecimentos comerciais ou edifícios para arrendar (habitacionais ou de outro tipo), estando-se, então, perante a existência de dois tipos de ativos imobiliários: os primeiros integram os chamados Ativos Tangíveis e os segundos Propriedades de Investimento.

Foi através da publicação do Decreto-lei n. ${ }^{\circ}$ 158/2009, de 13 de julho, que em Portugal se passou a adotar as Normas Internacionais de Contabilidade (IAS), por

$\mathrm{e}^{3}$ - Revista de Economia, Empresas e Empreendedores na CPLP | Volume 4 | Número 1 
imposição do Regulamento (CE) n. ${ }^{\circ}$ 1606/2002 e pela publicação do Aviso 15655/2009, de 7 de setembro, que as Normas Contabilísticas de Relato Financeiro (NCRF) foram oficialmente publicadas, definindo novas regras contabilísticas e de relato financeiro, entre eles, regras para a diferenciação e para o tratamento a dar a estes dois tipos de ativos.

\section{2 - $O$ conceito de justo valor na perspetiva contabilística}

Foi, após as publicações, acima referidas, que mais se começou a falar do Justo Valor, se bem que, ainda estando o antigo Plano Oficial de Contabilidade em vigor, a Diretriz Contabilística n. ${ }^{\circ} 1$ - Tratamento Contabilístico de Concentrações de Atividades Empresariais e a n. ${ }^{\circ} 13$ - Conceito de Justo Valor, já o referissem.

Essas duas diretrizes definiam o Justo Valor como sendo a quantia pela qual um bem (ou serviço) poderia ser trocado, entre um comprador conhecedor e interessado e um vendedor nas mesmas condições, numa transação ao seu alcance.

As NCRF definem o Justo Valor como sendo a quantia pela qual um ativo pode ser trocado ou um passivo liquidado, entre partes conhecedores e dispostas a isso numa transação onde não exista relacionamento entre elas.

Ainda com o POC em vigor, Carqueja (1995) refere que se justificam considerações pela dificuldade que tenho em compreender a diretriz contabilística $n{ }^{\circ} 13$ - Conceito de justo valor. Ferreira (1998) reforça que o termo justo é impróprio para qualificar valores recolhidos por referências ao mercado. É que neste não se fixam preços propriamente por critérios de justiça, porque no mercado o preço não se forma necessariamente por buscas do que é justo. Todos sabemos que, quando há excesso de oferta e insuficiências de procura e não se conseguem vender os bens, o preço de mercado baixa, descendo por vezes a valores ínfimos, derivados de leis do mercado, o que não se pode dizer que seja justo, a título nenhum.

Este conceito veio sobrepor o, até então, conceito do custo histórico e daí Iudícibus e Martins (2007) referirem que, ao colocarmos em contraposição o critério do justo valor com o do custo histórico, teremos, obviamente, de concluir que este é 


\section{pontěditora}

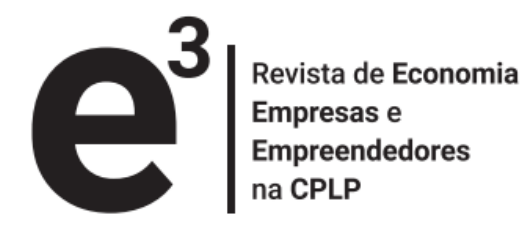

objetivo e que aquele é subjetivo. Ou seja, a relevação contabilística ao "Justo Valor" terá de ser aplicada com precaução (apelo ao princípio contabilístico "Da Prudência"), sob pena de afetarmos a contabilidade e as demonstrações financeiras de valores subjetivos, o que não facilita a decisão dos utilizadores. Iudícibus e Martins (2007) têm como opinião que foi nos ativos fixos que a introdução do justo valor teve repercussões mais assinaláveis, e veio introduzir novas regras de valorização onde o custo histórico tinha ainda um reduto mais significativo. Embora, como já se viu, também aí já temperado por alguns desvios. Mas tais desvios eram vistos como simples ajustes a um princípio central, não como elementos da mesma ordem de importância por comparação com o dito princípio. Ora, a extensão da aplicação do justo valor nos ativos fixos constitui o reforço de um rumo em direção a outro paradigma, remetendo o custo histórico para uma alternativa, muitas vezes de segundo plano, face ao novo método.

Também Iudícibus e Martins (2007), Costa, Silva e Laurencel (2013), Andrade, Silva e Malaquias (2013), Souza, Botinha, Silva e Lemes (2015) e Pinto, Martins e Silva (2015) levantaram igual problemática, colocando no seu estudo em debate duas questões fundamentais: a escolha do modelo de custos versus a escolha do modelo de valor justo para avaliação de propriedades para investimento.

\subsection{1 - Os ativos fixos tangíveis e as propriedades de investimento}

Sendo estes os tipos de ativos em análise neste trabalho, é de grande importância a análise das $\operatorname{NCRF}(s)$ que lhes estão subjacentes, nomeadamente a NCRF 7, para os Ativos Fixos Tangíveis, e a NCRF 11, para as Propriedades de Investimento.

\subsubsection{1 - Os ativos fixos tangíveis}

A NCRF 7, no seu $\S 6$, define Ativos Fixos Tangíveis como sendo todos aqueles detidos para uso na produção, para fornecimento de bens ou serviços, para arrendamento a outros, ou para fins administrativos e que se espera que sejam usados durante mais do que um período. Ainda que a NCRF 7 trate de todos os bens móveis e imóveis, somente estes últimos serão abordados neste subcapítulo por estarem diretamente relacionados com este trabalho. 


\section{pontěditora}

Pela definição dada pelo $\S 6$, acima referido, pode concluir-se que os ativos tangíveis imobiliários são todas as propriedades ocupadas pelo dono, essenciais para o desenvolvimento do seu próprio negócio.

\subsubsection{2 - As propriedades de investimento}

É a NCRF 11 que trata as Propriedades de Investimento, que se entendem como sendo "Imóveis de Rendimento". Esta Norma teve como base a IAS n. ${ }^{\circ}$ 40, que em inglês se denomina Investement Property.

Estas Propriedades de Investimento, cuja definição é dada no § 5 desta Norma, são todas aquelas que, sendo terrenos ou edifícios, ou parte de um edifício ou mesmo ambos, são detidos, pelo seu proprietário ou pelo locatário de uma locação financeira, para obter rendas ou para valorização de capital, ou para ambas as situações.

Tal como no subcapítulo anterior, é apresentada a Figura 2 com os principais parágrafos do Sistema de Normalização Contabilístico (SNC) relevantes para o estudo em causa.

Figura 2 - NCRF 11 - Propriedades de Investimento: Parágrafos relevantes

$\S 16$ - Reconhecimento inicial

$\S 21$ - Componentes do custo
- Provável que os benefícios económicos futuros que lhes estejam associados fluirão para a empresa;

- O seu custo possa ser fiavelmente mensurado.

- O preço da compra;

- As remunerações de profissionais por serviços legais prestados;

- Impostos de transferência de propriedade;

- Outros custos incorridos no momento da aquisição. 
$\S \mathbf{3 0}$ - Mensuração subsequente

$\S 58$ -

$\S \S 35$ a 57 - Modelo do Justo Valor
- O Modelo do custo;

- O Modelo do justo valor.

O justo valor pode ser obtido recorrendo:

- A avaliações efetuadas por entidades especializadas de modo a que os preços correntes no mercado ativo sejam fornecidos;

- Ou na ausência destas avaliações a:

- Preços correntes num mercado ativo de propriedades de diferente natureza, condição ou localização (ou sujeitas a diferentes locações ou outros contratos), ajustados para essas diferenças;

- Preços recentes em mercados menos ativos, ajustados de modo a refletir quaisquer alterações nas condições económicas desde a data em que essas transações ocorreram;

- Projeções de fluxos de caixa descontados, baseadas em estimativas fiáveis de fluxos de caixa futuros, usando taxas de desconto que reflitam avaliações correntes de mercado sobre a incerteza na quantia e tempestividade dos fluxos de caixa.

Fonte: Elaborada pelos autores.

O § 32 desta norma é de primordial importância para este trabalho já que vem incentivar as entidades, se bem que não o exige que determinem "o justo valor das propriedades de investimento na base de uma valorização por um avaliador independente que tenha uma qualificação profissional relevante e reconhecida e que tenha experiência recente na localização e na categoria da propriedade de investimento que esteja a ser valorizada". 


\section{pontěditora}

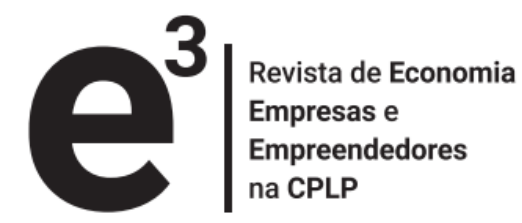

\subsection{3 - A análise económica e financeira}

Pode definir-se a análise económica e financeira como um conjunto de técnicas que facultam informações sobre a situação económica, financeira e monetária das empresas, baseando-se na informação contabilística e financeira, que permitem analisar a atividade e a sua estrutura financeira, num ou mais períodos económicos.

O seu objetivo principal é extrair das demonstrações financeiras, que se querem preparadas de forma a ilustrar uma imagem verdadeira e apropriada e por isso fidedigna, informação para a análise económica e financeira das entidades, bem como a sua evolução ao longo de um ou mais períodos. A análise financeira vai permitir, por um lado, aferir se as entidades dispõem de meios financeiros necessários às suas exigências operacionais e, por outro, verificar se pode vir a dispor desses meios, de uma forma autónoma, sem ter de recorrer a terceiros. Irá permitir, também, aferir a sua capacidade de gerar lucros, de forma a satisfazer os utentes interessados na organização, demonstrando, assim, a sua sobrevivência e expansão.

A informação contabilística e financeira necessária para a elaboração da análise, acima referida, é as Demonstrações Financeiras, nomeadamente o Balanço e a Demonstração de Resultados por Natureza, que fornecem uma panóplia de informação que, após estudadas e trabalhadas, serão utilizadas na análise da estrutura financeira das empresas.

Para que se possa elaborar a análise financeira, os autores apoiam-se na teoria dos indicadores. Como refere Neves (2012), podem construir-se inúmeros indicadores, mas a sua utilização vai depender, sobretudo, dos objetivos da análise, qual a natureza dos fenómenos que pretende revelar ou medir, que fontes de informação se vão utilizar, etc., em função da natureza dos fenómenos a revelar.

$\mathrm{Na}$ Figura 3, poder-se-á melhor entender a relação entre os indicadores existentes e os fenómenos a revelar. 
Figura 3 - Tipos de Indicadores e a sua interpretação

\section{Tipos de indicadores}

Financeiros

Económicos

Económico-

financeiros

Funcionamento

Técnicos

\section{Finalidade}

Apreciam os aspetos que se relacionam exclusivamente com os aspetos financeiros, a capacidade de endividamento, a solvabilidade, etc.

Pretendem revelar aspetos de situação económica, como a estrutura dos custos, a estrutura dos proveitos, as margens, a capacidade de auto financiamento, etc.

Pretendem apreender os aspetos económico-financeiros, como sendo a rendibilidade dos capitais, as rotações dos diferentes elementos do ativo, etc.

Ajudam a explicar os impactos financeiros da gestão ao nível do ciclo de exploração.

Procuram revelar aspetos relacionados com a produção e as atividades em geral, expressando-se, normalmente, em unidades físicas, ou comparando unidades económicofinanceiras com unidades físicas. Estuda-se com eles o rendimento do equipamento, a produtividade em mão de obra, etc.

Fonte: Adaptado de Neves (2012)

\section{3 - ESTUDO EMPÍRICO}

Este estudo tem como objetivo concluir como é que, e perante a atualização dos valores dos ativos tangíveis imobiliários, por via de uma revalorização, uma entidade vê a sua posição financeira alterada, tanto ao nível das rubricas de balanço, como ao nível da sua análise financeira.

Antes de se avançar com o estudo, propriamente dito, será efetuada uma abordagem à metodologia utilizada, os seus conceitos e ferramentas auxiliares. 


\section{pontěditora}

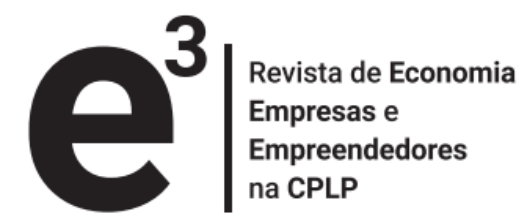

\section{1 - Metodologia}

Este estudo empírico, ao pretender saber quais os efeitos que os valores apurados por uma avaliação imobiliária produziriam, se fossem considerados na contabilidade de uma entidade, para efeitos da mensuração dos seus ativos e, consequentemente, os efeitos na sua análise financeira, originou a necessidade de serem estudados assuntos de áreas diferentes.

Tendo como base as Demonstrações Financeiras de uma entidade, do exercício de N, e uma Avaliação Imobiliária, ocorrida nesse mesmo ano às suas instalações industriais, este estudo pretende apurar, que efeitos são que os valores dessa avaliação teriam nas Demonstrações Financeiras dessa entidade, caso tivessem sido utilizadas para a revalorização dos seus ativos imobiliários, fazendo comparações e análises a dois cenários: antes e após revalorização.

Ao nível dos procedimentos técnicos que este estudo pode ser classificado de diferentes formas. Em primeiro lugar, é um estudo de caso e Silva (2004) refere que assim o é quando envolve o estudo profundo e exaustivo de um ou poucos objetos, de maneira que se permita o seu amplo e detalhado conhecimento; em segundo lugar, pode ser considerado como uma pesquisa experimental. Por último, este estudo pode ser classificado como ex post facto já que é um estudo experimental realizado após os acontecimentos dos factos. A este respeito, Carmo e Ferreira (2008) referem que esta investigação se designa por post-facto, porque a causa e o efeito já ocorreram e são estudados retrospetivamente.

Neste trabalho foram ainda calculados diversos indicadores, nomeadamente:

\section{a) Indicadores Financeiros}

$\begin{aligned} \text { Indicador de Solvabilidade }= & \text { Capital Próprio } \\ & \text { Passivo Total }\end{aligned}$

Autonomia Financeira $=\quad$ Capital Próprio

Capital Próprio + Capital Alheio

$\mathrm{e}^{3}$ - Revista de Economia, Empresas e Empreendedores na CPLP | Volume 4 | Número 1 


\section{pontěditora}

\author{
Indicador de \\ endividamento $=$ Passivo Corrente + Passivo não Corrente \\ Ativo Total
}

\section{b) Indicadores Económico-Financeiros}
Rendibilidade capital próprio $=$ Resultado Líquido

Capital Próprio

Rendibilidade do ativo $=$ Resultado antes de juros e impostos X 100

Ativo Total

\section{c) Indicadores de Funcionamento}
Rotação do ativo $=$ Vendas e Prestações de Serviços X 100
Ativo Total

Assim sendo, foram calculados indicadores económicos e financeiros e utilizadas as Demonstrações Financeiras de uma entidade, prontamente cedidas pelo Órgão de Gestão da mesma, bem como um Relatório de uma Avaliação Imobiliária, encomendado por essa entidade a uma empresa especializada.

\section{2 - Apresentação dos resultados}

A entidade, integrada num Grupo Internacional de renome, está sediada no Concelho de Santa Maria da Feira, em Portugal, tendo como CAE (Rev.3.) o código 15201 e tendo sido objeto de reestruturações e downsizing, viu-se na necessidade de efetuar testes de imparidade aos seus ativos tangíveis móveis e imóveis. Independentemente da técnica utilizada para os bens móveis e para a os seus bens imóveis, por tal para as suas instalações fabris, decidiu a Administração proceder a uma avaliação imobiliária, a meio de $\mathrm{N}$, tendo recorrido aos serviços de uma empresa especialista nesta área. 


\section{pontěditora}

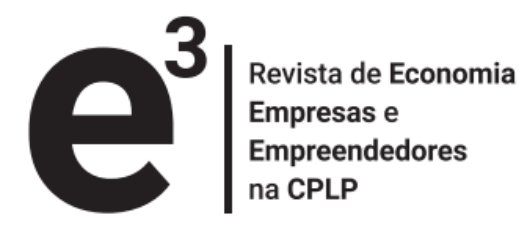

A empresa especialista, incumbida pela entidade, definiu, no seu relatório de avaliação, que o Objetivo da Avaliação seria proceder à avaliação do imóvel em questão para fins contabilísticos. Quanto aos valores de avaliação, esta empresa especialista utilizou:

- O Valor de Mercado em Uso Continuado corresponde ao montante que pode ser razoavelmente esperado pela transação, entre um comprador e um vendedor interessados, com equidade entre ambos, nenhum deles estando obrigado a vender ou a comprar e ambos estando conhecedores de todos os fatores relevantes a uma determinada data. Este valor pressupõe que as instalações estão adaptadas ao uso atual e futuro e que estão totalmente utilizadas;

- O Valor Indicativo de Liquidação representa o valor do imóvel, pressupondo a sua venda pública forçada após os melhores esforços de oferta, durante um curto período de tempo (entre três a seis meses);

- O Valor de Reconstrução a Novo corresponde ao montante necessário para reconstruir um imóvel semelhante ao imóvel em avaliação, incluindo a componente dos custos diretos e indiretos de construção. Este valor não inclui o valor do terreno nem o da margem de lucro e risco de promoção.

No que respeita às premissas da avaliação, a elaboração do Relatório foi antecedida de uma visita detalhada ao imóvel, com vista a verificar as suas características e a sua envolvente. Os valores de avaliação apresentados pressupõem que o imóvel, tal como nos foi apresentado, encontra-se devidamente legalizado e que tem licença de utilização para os fins a que se destina. Considerou-se, ainda, que não incidem sobre o imóvel quaisquer ónus ou encargos, não tendo sido verificada a respetiva situação jurídica ou fiscal.

A avaliação foi baseada na documentação fornecida pelo proponente e no levantamento de mercado efetuado. Foi, ainda, realizada na ótica do uso continuado através do Método dos Custos Correntes e Substituição de Fatores e do Método de Comparação de Mercado, considerando o imóvel livre e disponível. Foram 


\section{pontěditora}

consideradas, na avaliação, as áreas estimadas através dos elementos fornecidos pelo Cliente, nomeadamente a certidão de teor, caderneta predial e planta da arquitetura.

O valor Indicativo de Liquidação (VIL) é obtido pela aplicação da seguinte fórmula: $\mathrm{VIL}=\mathrm{VM} *(1+\mathrm{r})^{\mathrm{n}}$; sendo $V M$ o valor de mercado, $r$ a taxa de atualização e $n$ o número de períodos de tempo. Tendo por base todos os pressupostos atrás mencionados, a empresa especialista conclui que, na Ótica do Uso Continuado, considerando o Imóvel Livre e Disponível, os valores seriam os apresentados na Figura 4.

Figura 4 - Valores na Ótica do Uso Continuado
Valor de Mercado
$6.876 .000 €$
Valor Indicativo de Liquidação
$4.700 .000 €$
Valor de Reconstrução a Novo
$6.406 .000 €$

Fonte: Elaborada pelos autores.

É com base nos dados deste relatório que se passa, de imediato, ao estudo de experimentação.

\subsection{1 - O estudo de experimentação}

O Balanço e a Demonstração de Resultados do exercício de N apresentavam os seguintes valores (Tabela 1 e Tabela 2):

Tabela 1 - O Balanço a 31/12/N

\begin{tabular}{ll}
\hline Rubricas & Valores \\
\hline Ativo & $31-12-\mathrm{N}$ \\
\hline Ativo não corrente & \\
Ativos Fixos Tangíveis & $2.469 .594,38$ \\
Outros ativos não correntes & $148.644,05$ \\
Ativos Correntes & $12.963 .821,77$ \\
\hline Total do Ativo & $15.582 .060,20$ \\
\hline
\end{tabular}

$\mathrm{e}^{3}$ - Revista de Economia, Empresas e Empreendedores na CPLP | Volume 4 | Número 1 


\section{Capital Próprio e Passivo}

Capital Próprio

Passivo não corrente

Passivo corrente
14.029.434,28

$292.949,92$

1.259.676,00

\section{Total do Passivo}

$15.582 .060,20$

Fonte: Elaborada pelos autores e preparado a partir das Demonstrações Financeiras da Entidade (2016)

Tabela 2 - A Demonstração de Resultados de N

\section{RENDIMENTOS E GASTOS \\ a $31 / 12 / \mathrm{N}$}

Vendas e serviços prestados

$7.066 .909,50$

Variação nos inventários da produção

$25.744,15$

Trabalhos para a própria entidade

$2.015,17$

Custo das mercadorias vendidas e das matérias consumidas

$-2.029 .811,29$

Fornecimentos e serviços externos

$-1.294 .520,46$

Gastos com o pessoal

$-3.686 .807,02$

Imparidade de ativos não depreciáveis (perdas/reversões)

$9.146,25$

Provisões (aumentos/reduções)

$85.916,46$

Outros rendimentos e ganhos

$672.268,26$

Outros gastos e perdas

$-179.940,69$

Resultado antes de depreciações, gastos de financiamento

e impostos

$670.920,33$

Gastos/reversões de depreciações e de amortizações

$-856.450,90$

Imparidade de investimentos depreciáveis/amortizáveis

(perdas/reversões)

$132.441,23$

\section{Resultado operacional antes de gastos de financiamento}

e impostos

$-53.089,34$

Juros e rendimentos similares obtidos

$142.564,96$

Juros e gastos similares ocorridos

$-9.354,45$

\section{Resultado antes de impostos}


Imposto sobre o rendimento do período

$111.679,93$

\section{Resultado líquido do período}

191.801,10

Fonte: Elaborada pelos autores e preparado a partir das Demonstrações Financeiras da Entidade (2016)

Os Ativos Fixos Tangíveis apresentavam a decomposição apresentada na Tabela 3.

Tabela 3 - Decomposição dos Ativos Fixos Tangíveis

\begin{tabular}{llll}
\hline Ativos Tangíveis & Custo Aquisição & Depreciações & Quantia Escriturada \\
\hline Terrenos & $531.484,47$ & 0,00 & $531.484,47$ \\
Edifícios e outras construções & $4.863 .853,71$ & $-3.810 .003,67$ & $1.053 .850,04$ \\
Equipamento básico & $11.092 .023,74$ & $-10.322 .091,54$ & $769.932,20$ \\
Equipamento de transporte & $158.300,88$ & $-156.339,68$ & $1.961,20$ \\
Equipamento administrativo & $1.913 .813,43$ & $-1.827 .001,58$ & $86.811,85$ \\
Outros ativos tangíveis & $66.471,49$ & $-55.407,03$ & $11.064,46$ \\
Ativos tangíveis em curso & $14.490,16$ & 0,00 & $14.490,16$ \\
\cline { 2 - 4 } Total & $\mathbf{1 8 . 6 4 0 . 4 3 7 , 8 8}$ & $\mathbf{- 1 6 . 1 7 0 . 8 4 3 , 5 0}$ & $\mathbf{2 . 4 6 9 . 5 9 4 , 3 8}$
\end{tabular}

$\overline{\text { Fonte: Elaborada pelos autores e preparado a partir das Demonstrações Financeiras da Entidade (2016) }}$

O Capital Próprio decompunha-se conforme a Tabela 4.

Tabela 4 - Decomposição do Capital Próprio

\begin{tabular}{ll}
\hline Capital Próprio & Valor \\
\hline Capital realizado & $2.770 .000,00$ \\
Reservas legais & $652.760,70$ \\
Outras reservas & $4.492 .681,62$ \\
Resultados transitados & $5.892 .952,26$ \\
Outras variações de capital próprio & $29.238,60$ \\
Resultado do ano & $191.801,10$ \\
\end{tabular}

$\mathrm{e}^{3}$ - Revista de Economia, Empresas e Empreendedores na CPLP | Volume 4 | Número 1 
Fonte: Elaborada pelos autores e preparado a partir das Demonstrações Financeiras da Entidade (2016)

Demonstrados que estão os valores do Relato Financeiro da entidade, do ano de N, e comparando o valor contabilístico dos bens imóveis com os apurados pela empresa especialista, conclui-se que não existia imparidade a este nível, pois os valores, dados por essa avaliação, eram de facto muito mais elevados do que os apresentados pela contabilidade, e ao mesmo tempo os Órgãos de Gestão da entidade decidiram pela não atualização dos ativos em causa, ou melhor pela não revalorização dos mesmos, tendose mantido, assim, o modelo do custo, seguindo o definido no $§ 30$ da NCRF 7.

No entanto, se a entidade tivesse optado pela revalorização, que seria considerada uma "Revalorização Livre", pois nenhum Diploma Legal the estaria subjacente, e tomando como valor de referência o valor de mercado apurado pela empresa especialista, teria de proceder ao ajuste do valor do Terreno e dos Edifícios e Outras Construções, de acordo com os cálculos apresentados na Tabela 5.

Tabela 5 - Apuramento do Valor do Excedente de revalorização

\begin{tabular}{llllll}
\hline Itens & $\begin{array}{l}\text { Valor da } \\
\text { avaliação }\end{array}$ & $\begin{array}{l}\text { \% de } \\
\text { distribuição }\end{array}$ & $\begin{array}{l}\text { Valor a } \\
\text { atribuir }\end{array}$ & $\begin{array}{l}\text { Valor líquido } \\
\text { contabilizado }\end{array}$ & $\begin{array}{l}\text { Excedente de } \\
\text { revalorização }\end{array}$ \\
\hline & $\mathbf{6 . 8 7 6 . 0 0 0 , 0 0}$ & & $\mathbf{1 . 5 8 5 . 3 3 4 , 5 1}$ & $\mathbf{5 . 2 9 0 . 6 6 5 , 4 9}$ \\
Terrenos & $25,00 \%$ & $\begin{array}{l}1.719 .000 \\
, 00\end{array}$ & $531.484,47$ & $1.187 .515,53$ \\
Edifícios e & & 00 & & \\
$\begin{array}{l}\text { outras } \\
\text { construções }\end{array}$ & $75,00 \%$ & 5.157 .000 & $1.053 .850,04$ & $4.103 .149,96$ \\
\hline Fonte: Elaborada pelos autores e preparado com base na avaliação da empresa especialista (2016)
\end{tabular}

Fonte: Elaborada pelos autores e preparado com base na avaliação da empresa especialista (2016)

Seriam, após este apuramento, os seguintes lançamentos contabilísticos a efetuar, de acordo com a NCRF 7 (Tabela 6). 
Tabela 6 - Lançamentos Contabilísticos da Revalorização

\begin{tabular}{|c|c|c|c|c|}
\hline $\begin{array}{l}\text { Tipo de } \\
\text { movimento }\end{array}$ & Conta a débito & Conta a crédito & Valor & NCRF 7 \\
\hline $\begin{array}{l}\text { Pela anulação das } \\
\text { depreciações } \\
\text { acumuladas }\end{array}$ & $\begin{array}{l}438 \text { - Depreciações } \\
\text { acumuladas }\end{array}$ & $\begin{array}{l}432 \text { - Edifícios e } \\
\text { outras construções }\end{array}$ & $3.810 .003,67$ & $\S 35 b)$ \\
\hline \multirow{2}{*}{$\begin{array}{l}\text { Pelo registo da } \\
\text { revalorização da } \\
\text { quantia escriturada } \\
\text { do ativo fixo } \\
\text { tangível }\end{array}$} & 431 - Terreno & $\begin{array}{l}58 \text { - Excedentes de } \\
\text { revalorização de } \\
\text { ativos fixos tangíveis }\end{array}$ & $1.187 .515,53$ & $\S 39$ \\
\hline & $\begin{array}{l}432 \text { - Edifícios e } \\
\text { outras construções }\end{array}$ & $\begin{array}{l}58 \text { - Excedentes de } \\
\text { revalorização de } \\
\text { ativos fixos tangíveis }\end{array}$ & $4.103 .149,96$ & $\S 39$ \\
\hline $\begin{array}{l}\text { Pelo valor do } \\
\text { imposto diferido }\end{array}$ & $\begin{array}{l}5892 \text { - Excedentes } \\
\text { de revalorização de } \\
\text { ativos fixos } \\
\text { tangíveis - impostos } \\
\text { diferidos }\end{array}$ & $\begin{array}{l}2742 \text { - Passivos por } \\
\text { impostos diferidos }\end{array}$ & $1.402 .026,35$ & $\S 42$ \\
\hline
\end{tabular}

Fonte: Elaborada pelos autores.

Desta forma, passariam o Balanço (Tabela 7) e a Decomposição dos Ativos Fixos Tangíveis e Capital Próprio (Tabela 9) a apresentar os seguintes valores:

Tabela7 - Balanço após Revalorização

\begin{tabular}{ll}
\hline Rubricas & Valores \\
\hline Ativo & $\mathbf{3 1 - 1 2 - N}$ \\
\hline Ativo não Corrente & $7.760 .259,87$ \\
Ativos Fixos Tangíveis & $24.964,12$ \\
Outros Ativos não Correntes & $12.963 .821,77$ \\
Ativos Correntes & $\mathbf{2 0 . 7 4 9 . 0 4 5 , 7 6}$ \\
\hline Total do Ativo & $17.918 .073,42$ \\
\hline Capital Próprio e Passivo & \\
Capital Próprio & \\
&
\end{tabular}




\section{pontěditora}

Passivo não Corrente

$1.571 .296,34$

Passivo Corrente

Total do Passivo

Fonte: Elaborada pelos autores.

Tabela 8 - Decomposição do Ativo Fixo Tangível após Revalorização

\begin{tabular}{llll}
\hline Ativos Tangíveis & $\begin{array}{l}\text { Custo Aquisição/ } \\
\text { Revalorização }\end{array}$ & Depreciações & Valor líquido \\
\hline Terrenos & $1.719 .000,00$ & 0,00 & $1.719 .000,00$ \\
Edifícios e outras construções & $5.157 .000,00$ & 0,00 & $5.157 .000,00$ \\
Equipamento básico & $11.092 .023,74$ & $-10.322 .091,54$ & $769.932,20$ \\
Equipamento de transporte & $158.300,88$ & $-156.339,68$ & $1.961,20$ \\
Equipamento administrativo & $1.913 .813,43$ & $-1.827 .001,58$ & $86.811,85$ \\
Outros ativos tangíveis & $66.471,49$ & $-55.407,03$ & $11.064,46$ \\
Ativos tangíveis em curso & $14.490,16$ & 0,00 & $14.490,16$ \\
Total & $\mathbf{2 0 . 1 2 1 . 0 9 9 , 7 0}$ & $\mathbf{- 1 2 . 3 6 0 . 8 3 9 , 8 3}$ & $\mathbf{7 . 7 6 0 . 2 5 9 , 8 7}$ \\
\hline
\end{tabular}

Fonte: Elaborada pelos autores.

Tabela 9 - Decomposição do Capital Próprio após Revalorização

\begin{tabular}{ll}
\hline Capital Próprio & Valor \\
\hline Capital realizado & $2.770 .000,00$ \\
Reservas legais & $652.760,70$ \\
Outras reservas & $4.492 .681,62$ \\
Resultados transitados & $5.892 .952,26$ \\
Reservas de revalorização & $3.888 .639,14$ \\
Outras variações de capital próprio & $29.238,60$ \\
Resultado do ano & $191.801,10$ \\
Total & $\mathbf{1 7 . 9 1 8 . 0 7 3 , 4 2}$ \\
\hline
\end{tabular}

Fonte: Elaborada pelos autores.

$\mathrm{e}^{3}$ - Revista de Economia, Empresas e Empreendedores na CPLP | Volume 4 | Número 1 


\section{pontěditora}

Passar-se-ia, posteriormente, à apresentação dos resultados dos indicadores apurados com os valores dos dois cenários (Tabela 10)

Tabela 10 - Cálculo dos Indicadores

\begin{tabular}{|c|c|c|c|}
\hline Indicadores & Equação & $\begin{array}{l}\text { Antes da } \\
\text { revalorização }\end{array}$ & $\begin{array}{l}\text { Após } \\
\text { Revalorização }\end{array}$ \\
\hline Solvabilidade & $\begin{array}{c}(\text { Capital próprio } \div \text { passivo total }) \times \\
100\end{array}$ & $903,59 \%$ & $632,93 \%$ \\
\hline $\begin{array}{l}\text { Autonomia } \\
\text { Financeira }\end{array}$ & $\begin{array}{c}\text { Capital próprio } \div \text { Capital Próprio }+ \\
\text { Capital alheio } \times 100\end{array}$ & $90,04 \%$ & $86,36 \%$ \\
\hline Endividamento & $\begin{array}{l}\text { Passivo corrente e não corrente } \div \\
\text { Ativo Total } \times 100\end{array}$ & $9,96 \%$ & $13,64 \%$ \\
\hline $\begin{array}{l}\text { Rendibilidade } \\
\text { do Capital Próprio }\end{array}$ & $\begin{array}{l}\text { Resultado líquido do período } \div \\
\text { Capital Próprio } \times 100\end{array}$ & $1,37 \%$ & $1,07 \%$ \\
\hline $\begin{array}{l}\text { Rendibilidade } \\
\text { Económica do Ativo }\end{array}$ & $\begin{array}{l}\text { Resultado antes de juros e Impostos } \\
\quad \div \text { Ativo Total } \times 100\end{array}$ & $-0,34 \%$ & $-0,26 \%$ \\
\hline Rotação do Ativo & $\begin{array}{l}\text { Vendas e Prestação de serviços } \div \\
\text { Ativo Total } \times 100\end{array}$ & $45,35 \%$ & $34,06 \%$ \\
\hline
\end{tabular}

Fonte: Elaborada pelos autores.

\section{3 - Discussão dos resultados}

Analisa-se e comenta-se de seguida os efeitos a que a entidade estaria sujeita se a revalorização tivesse sido efetuada.

\subsection{1 - Variações ao nível do Balanço}

Alterações que a revalorização provocaria ao nível do Balanço são apresentadas na Tabela 11. 
Tabela 11 - Análise vertical do Balanço antes e após revalorização

\begin{tabular}{|c|c|c|c|c|}
\hline \multirow{2}{*}{$\begin{array}{l}\text { Rubricas } \\
\text { Ativo }\end{array}$} & \multicolumn{2}{|c|}{ Antes da revalorização } & \multicolumn{2}{|c|}{ Após revalorização } \\
\hline & Valor $€$ & $\begin{array}{l}\text { (peso relativo) } \\
\%\end{array}$ & Valor $€$ & $\begin{array}{l}\text { (peso relativo) } \\
\%\end{array}$ \\
\hline \multicolumn{5}{|l|}{ Ativo não corrente } \\
\hline Ativos Fixos Tangíveis & $2.469 .594,38$ & $15,85 \%$ & $7.760 .259,87$ & $37,40 \%$ \\
\hline $\begin{array}{l}\text { Outros ativos não } \\
\text { correntes }\end{array}$ & $148.644,05$ & $0,95 \%$ & $24.964,12$ & $0,12 \%$ \\
\hline Ativos Correntes & 12.963.821,77 & $83,20 \%$ & $12.963 .821,77$ & $62,48 \%$ \\
\hline Total do Ativo & $15.582 .060,20$ & 1,00 & $20.749 .045,76$ & $1,1,00$ \\
\hline \multicolumn{5}{|l|}{ Capital Próprio e } \\
\hline \multicolumn{5}{|l|}{ Passivo } \\
\hline Capital Próprio & $14.029 .434,28$ & $90,04 \%$ & $17.918 .073,42$ & $86,36 \%$ \\
\hline Passivo não corrente & $292.949,92$ & $1,88 \%$ & $1.571 .296,34$ & $7,57 \%$ \\
\hline Passivo corrente & $1.259 .676,00$ & $8,08 \%$ & $1.259 .676,00$ & $6,07 \%$ \\
\hline Total do Passivo & $15.582 .060,20$ & $1,1,00$ & 20.749.045,76 & $1,1,00$ \\
\hline
\end{tabular}

Fonte: Elaborada pelos autores.

Sendo a análise vertical uma forma de se verificar a importância de cada rubrica no total do Balanço, ou de uma outra forma de se compreender a estrutura patrimonial de uma empresa, pode-se concluir que a revalorização alteraria significativamente algumas rubricas.

O peso dos Ativos Correntes, diretos responsáveis pela fonte de recursos a curto prazo, aqueles que são detidos com a finalidade de serem facilmente transformados em moeda (que têm um maior nível de liquidez) no decurso normal do seu ciclo operacional, sofreriam um decréscimo, passando de 83,20\%, antes da revalorização, para 62,48\%, depois desta. Contrariamente, o Ativo Não Corrente, por força do aumento dos Ativos Fixos Tangíveis, apresentaria um peso muito superior, pois passaria de $15,85 \%$ para $37,40 \%$, demonstrando desta forma que os bens detidos numa perspetiva de continuidade ou permanência, sem terem como fim a sua transformação ou a venda rápida, seriam os que apresentariam um maior aumento.

Relativamente ao Passivo, a percentagem do Capital Próprio sofreria um ligeiro decréscimo, passando de 90,04\% para 86,36\%, o que, como se verificará, irá afetar a 


\section{pontěditora}

autonomia financeira, além de que, pode ser considerado como um valor residual, não podendo ser esquecido o facto deste corresponder ao património líquido da empresa. Quanto ao Passivo Corrente, este apresentaria um peso um pouco inferior, contrastando com o Passivo Não Corrente que passaria de 1,88\% para 7,57\%, cujo efeito será analisado na Tabela 12.

Tabela 12 - Variações ao nível das rúbricas do Balanço

\begin{tabular}{lll}
\hline $\begin{array}{l}\text { Rubricas } \\
\text { Ativo }\end{array}$ & Variação em $\boldsymbol{€}$ & Variação em \% \\
\hline . Ativos Fixos Tangíveis & $5.290 .665,49$ & $214,23 \%$ \\
. Outros Ativos não Correntes & $-123.679,93$ & $-83,21 \%$ \\
Ativos Correntes & 0,00 & $0,00 \%$ \\
\hline Total do Ativo & $\mathbf{5 . 1 6 6 . 9 8 5 , 5 6}$ & $\mathbf{3 3 , 1 6 \%}$ \\
\hline Capital Próprio e Passivo & & \\
Capital Próprio & $3.888 .639,14$ & $27,72 \%$ \\
Passivo não Corrente & $1.278 .346,42$ & $436,37 \%$ \\
Passivo Corrente & 0,00 & $0,00 \%$ \\
\hline Total do Passivo & $\overline{\mathbf{5 . 1 6 6 . 9 8 5 , 5 6}}$ & $\mathbf{3 3 , 1 6 \%}$ \\
\hline
\end{tabular}

Fonte: Elaborada pelos autores.

Ao nível da variação total do Balanço, o efeito desta operação, conforme demonstrado na Tabela 12, representaria um aumento de 33,16\%, muito abaixo do impacto que a revalorização originaria nos Ativos Fixos Tangíveis, cujo aumento seria de $214,23 \%$. Este aumento denota que os bens sujeitos à revalorização poderiam apresentar-se subavaliados, parecendo, por isso, não terem acompanhado as flutuações de preços ao longo das suas vidas úteis. No entanto ter-se-ia, também, de ter em consideração o efeito visível do desgaste "contabilístico", pois, ao ser analisado, o valor líquido que estes apresentavam antes da revalorização poder-se-ia concluir praticamente depreciados.

Quanto ao Capital Próprio, o efeito líquido da revalorização originaria um aumento de 27,72\%. Este aumento, analisado na Tabela 12, não evitaria a diminuição que este passaria a apresentar no peso do Balanço. 


\section{pontěditora}

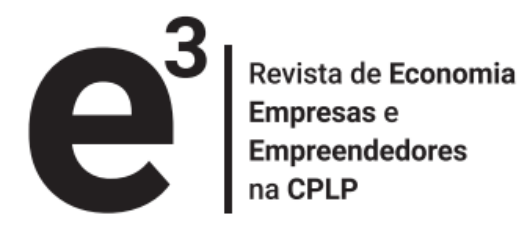

Os impostos diferidos sofreriam alterações, pois a entidade passaria de um reconhecimento de impostos diferidos ativos para impostos diferidos passivos, explicando a diminuição da rubrica "Outros Ativos não Correntes", de 83,21\%, e o aumento do Passivo não Corrente, 436,37\%. Esta situação deve-se ao facto de, na presença de revalorizações, o valor contabilístico do ativo ser aumentado, não o sendo, no entanto, a nível fiscal o que vai originar depreciações contabilísticas futuras de valor superior às fiscalmente aceites, no caso dos edifícios e potenciais mais valias futuras no caso dos terrenos. Assim, e de acordo com a NCRF 25 - Impostos sobre o Rendimento, estando-se na presença de diferenças temporárias, tributáveis em exercícios futuros, existe a obrigatoriedade de reconhecer o imposto diferido passivo, fazendo-se assim evidenciar as futuras obrigações fiscais a que as empresas irão estar sujeitas.

\subsection{2 - Variações ao nível da Demonstração das Alterações do Capital}

Seria ao nível do resultado integral que a Demonstração das Alterações de Capital apresentaria variações, passando este de um valor 178.585,06€ antes da revalorização para um valor de 4.067.224,20€ depois desta.

Sendo o resultado integral a agregação do resultado líquido do exercício (componente que demonstra os lucros/prejuízos reais de uma entidade, daí demonstrando a boa ou má performance dos seus Órgãos de Gestão) e variações no capital próprio (resultantes de variações ainda não realizadas e não diretamente ligadas à participação direta de sócios), poder-se-á dizer que os sócios veriam os seus lucros, substancialmente, acrescidos por eventos por eles não controláveis.

De salientar que o resultado integral, em anos futuros, irá sofrer mutações importantes, quer sejam estas por via da depreciação dos edifícios, que implicam que a Excedente de revalorização comece a ser diminuída (vulgo revalorização realizada) e transferida para resultados transitados, quer por via do recálculo do imposto diferido inicialmente apurado. Mutações acontecerão também ao nível do imposto diferido, calculado sobre a Excedente de revalorização do terreno, onde, nos anos futuros, este terá de ir sendo atualizado pelo pressuposto de que essa reserva somente será realizada por via de uma alienação. Desta forma, o seu custo histórico terá de ser sempre 
atualizado, ao longo dos anos, tendo em consideração o efeito da inflação acumulada. $\mathrm{O}$ novo valor, desta forma apurado, terá de ser comparado com o valor revalorizado, e a diferença passará a ser a nova diferença temporária tributável, à qual será aplicada a taxa de imposto subjacente, implicando, assim, ajustes anuais ao imposto diferido anteriormente contabilizado.

\subsection{3 - Variações ao nível dos indicadores}

Em termos de solvabilidade, e apesar deste indicador ter sofrido uma diminuição, pois passaria de $903,50 \%$ para $632,93 \%$, a entidade continuaria a refletir um baixo risco para os seus credores, já que os seus Ativos continuariam a ser mais que suficientes para liquidar as suas dívidas. A entidade apresentava, já anteriormente, uma margem de segurança muito elevada.

A autonomia financeira reduziria em cerca de $4 \%$, a questão que aqui se poderia colocar é se a entidade diminuiria a sua capacidade de financiar o seu ativo, através dos seus Capitais Próprios, e se, de facto, aumentaria a sua dependência face aos Capitais Alheios. Por seu lado, a entidade apresentaria, também, uma pior situação ao nível do endividamento. Ao apresentar um indicador mais alto estaria a aumentar o seu grau de risco e, consequentemente, a diminuir a capacidade de um futuro endividamento.

Quanto à rendibilidade do Capital Próprio seria mais um dos indicadores a ser negativamente afetado e aqui não se poderá tecer uma conclusão concreta, mas colocar algumas questões: será que os seus investidores passariam a ver a entidade como menos atraente, já que este é um indicador que pode ser comparado com a taxa de outros rendimentos, alternativos existentes no mercado, para se poder avaliar se as empresas oferecem rentabilidade superior ou inferior a essas opções disponíveis? A entidade ficaria com uma menor capacidade para se autofinanciar? Os Gestores passariam a não ser tão eficazes? Sendo este um dos indicadores, também, usado para a avaliação da performance dos Órgãos de Gestão, este pode ter sido, por certo, uma das razões pela decisão de não revalorizar os ativos em questão. Ficaria, a entidade, com maior capacidade de gerar lucros? Mesmo que para o cálculo fosse considerada a média aritmética, dos montantes apresentados no início e no final do ano, como preconizam 


\section{pontěditora}

Doná, Mucio, Moribe e Hercos Junior (2015), o indicador continuaria a apresentar uma melhoria. No entanto, este indicador pode ser calculado de uma outra forma e decomposto em duas componentes diferentes:

$$
\text { Rendibilidade do ativo }=\frac{\text { Resultados antes de juros e impostos }}{\text { Vendas }} \times \frac{\text { Vendas }}{\text { Ativo total }}(7)
$$

Sendo que a primeira componente, e de acordo com Doná et al. (2015), representa a rendibilidade operacional das vendas, procurando-se relacionar o resultado operacional com o volume de vendas obtido, referindo ainda que uma melhoria deste indicador pode refletir uma alteração dos preços de venda, uma melhoria ao nível dos custos dos fatores produtivos, ou uma maior eficiência na utilização desses mesmos fatores, enquanto a segunda componente representa a rotação do ativo, anteriormente já calculada. Assim, conforme a Tabela 13 teríamos:

Tabela 13 - Decomposição da Rendibilidade do Ativo

\begin{tabular}{lcc}
\hline Indicadores & $\begin{array}{c}\text { Antes da } \\
\text { revalorização }\end{array}$ & $\begin{array}{c}\text { Após revalorização } \\
\text { Rendibilidade operacional das vendas }\end{array}$ \\
$\begin{array}{l}-0,75 \% \\
\times\end{array}$ & $\begin{array}{c}-0,75 \% \\
\times\end{array}$ \\
Rotação do ativo & $45,35 \%$ & $34,06 \%$ \\
Rendibilidade do ativo & $-0,34 \%$ & $-0,26 \%$ \\
\hline
\end{tabular}

Fonte: Elaborada pelos autores.

A rendibilidade operacional das vendas não seria afetada. Esta situação deve-se ao facto da não ocorrência da revalorização e por tal a não afetação dos custos de produção (por via do aumento das depreciações) e, consequentemente, a não necessidade do aumento dos preços de venda. À primeira vista parece uma dedução lógica ou não fosse o tipo de atividade da entidade a contrariar esta lógica. Este tipo de atividade é essencialmente sazonal (a produção da estação outono/inverno acontece entre os meses de março e agosto e a estação primavera/verão entre os meses de 


\section{pontěditora}

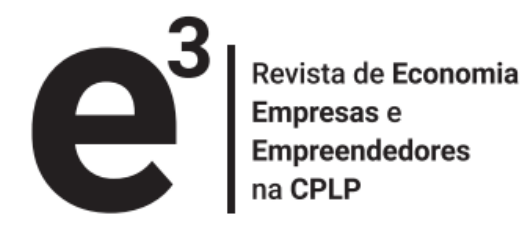

setembro e fevereiro do ano seguinte), existindo uma negociação prévia de preços de venda, com os seus clientes, de pelo menos uma estação. Assim, tendo a revalorização ocorrido, os novos preços de venda, refletindo os efeitos da revalorização (que somente foi do conhecimento da entidade a meio do ano N), somente, poderiam começar a ser praticados, na melhor das hipóteses, na estação outono/inverno do ano seguinte. Ora sendo já o resultado operacional negativo, a revalorização iria afetar mais negativamente esse resultado e, decerto, mais uma provável razão pela decisão de não revalorizar os ativos em questão.

Passando à Rotação do Ativo e sendo o seu resultado inferior à do cenário inicial, refletiria uma pior eficiência ao nível da utilização dos meios afetos à sua atividade? Neste caso a resposta seria não e a explicação passaria pela não alteração dos valores das vendas e pela sua divisão por um universo maior.

Como conclusão, poder-se-á referir que o aumento que ocorreria na Rendibilidade do Ativo não seria originado pela melhor performance operacional da entidade, ou pela melhor capacidade do ativo em gerar resultados, mas, somente, pela simples regra matemática dos valores negativos na multiplicação, pois um valor negativo, ao ser multiplicado por valores positivos, vai dando origem a valores menos negativos, à medida que esses valores positivos vão diminuindo.

Tendo adotado o método da revalorização, ter-se-ia de colocar a questão e tentar perceber se a entidade passaria a apresentar uma imagem mais verdadeira e apropriada das suas Demonstrações Financeiras. De facto, assim parece, pois o próprio valor de liquidação que a empresa especialista calculou (4.700.000€) era já bem superior ao valor contabilístico que o terreno e o valor dos edifícios e outras construções apresentavam $(1.585 .334,51 €)$.

\section{4 - CONCLUSÃO}

Nesta nova era contabilística "o valor" tem tomado uma importância cada vez maior. Este valor, o usado nos meios financeiros e contabilísticos tem (tinha?) um significado simples, pois, sendo os ativos e passivos registados ao seu custo histórico, o seu conceito seria fácil de entender. No entanto, o SNC veio enfatizar um outro 


\section{pontěditora}

conceito, o conceito do Justo Valor. Este conceito, em termos de normativo português não era novo, como é o caso da Diretriz Contabilística n. ${ }^{\circ} 13$ - Conceito de Justo Valor, mas o SNC veio incentivar o seu uso, de modo a que os ativos passassem a ser reconhecidos a preços mais atuais, a preços de mercado, ao seu justo valor e em detrimento do seu custo, do seu custo histórico.

O SNC ao longo das suas $28 \mathrm{NCRF}(\mathrm{s})$ vai dando indicações dos tipos de ativos que podem ser mensurados, nas Demonstrações Financeiras, ao correspondente de justo valor. São exemplo desses ativos os bens imobiliários, quer estes estejam integrados em Ativos Fixos Tangíveis quer em Propriedades de Investimento.

Preconizam as $\operatorname{NCRF}(\mathrm{s})$, destes dois tipos de ativos, que o Justo Valor corresponde ao Modelo de Revalorização para os imóveis inseridos nos Ativos Fixos Tangíveis e o Modelo do Justo Valor para os imóveis reconhecidos como Propriedades de Investimento. Mas para que tal aconteça, as regras são muito claras, o justo valor tem de ter por base uma avaliação, efetuada por avaliadores profissionais, qualificados e independentes e que, para o caso das Propriedades de Investimento, devem ter, ainda, experiência recente na localização e na categoria do imóvel que esteja a ser valorizado.

A Avaliação Imobiliária, que muitos ainda se interrogam se será uma "Arte" ou uma "Ciência", e daí Tavares (2011) ter a opinião de que se é verdade que a avaliação do imobiliário é uma arte, é também com certeza uma ciência. A atribuição de valor a bens imóveis, quer sejam estes terrenos, edifícios ou quaisquer outras construções, aumentam a satisfação da utilização do espaço, para quem o usa, para quem o explora e para quem o produz. O seu objetivo é o de obter um preço que possa ser utilizado numa transação entre um comprador e um vendedor interessados nessa transação.

Ao não ser possível a simples comparação com imóveis semelhantes, terão de existir métodos específicos para cada caso. Estes métodos de avaliação, ou melhor dizendo de cálculo, que originarão o valor final da avaliação, dependem de fatores como: a tipologia do imóvel; a quantidade e qualidade da informação existente no mercado; a própria localização e, também de grande importância, a finalidade da avaliação. Cabe ao avaliador, apresentar um relatório, também este objetivo, fiável e 


\section{pontěditora}

que descreva logicamente, além das análises efetuadas, os métodos utilizados de modo a suportar as estimativas dos valores apresentados.

A regra dos ajustes destes valores têm impacto direto no Capital Próprio das empresas, independentemente de serem originados pelo aumento ou pela diminuição do valor dos seus Ativos Imobiliários, que numa primeira fase apresentar-se-iam valorizados ao seu custo histórico.

Ora, sendo os Ativos Fixos Tangíveis e o Capital Próprio as duas mais importantes rubricas para a elaboração da Análise Financeira, facilmente se conclui que qualquer variação ao nível do valor destas tem influência nos resultados dos indicadores calculados.

A grande questão que aqui se poderá colocar é, e na presença de aumentos ou diminuições ao nível do Capital Próprio e dos Ativos Não Correntes, compreender até que ponto, as empresas vêem a sua estrutura financeira, ou melhor dizendo, a sua política de financiamento alterada, a sua rendibilidade económica e financeira afetada e mesmo se esses impactos levam à conclusão que a própria Gestão tivesse alterado o seu nível de eficiência.

O estudo efetuado demonstrou que os ajustes da revalorização, provenientes de aumentos do valor dos Ativos Imobiliários, tiveram uma influência negativa aos níveis dos indicadores de Solvabilidade, Autonomia Financeira e Endividamento, concluindose que, por um lado, a capacidade da entidade para fazer face aos seus compromissos a médio e longo prazo fosse menor o que, inversamente, aumentaria o risco que, por ventura, os seus credores correriam.

No que diz respeito à Rendibilidade Financeira, esta é também negativamente afetada, pois o indicador da Rendibilidade do Capital Próprio diminui perante um aumento, neste caso, proveniente de Reservas de Revalorização. A questão que aqui se poderá levantar é se esta diminuição poderá demonstrar uma alteração ao modo como a empresa utiliza os capitais pertencentes aos seus participantes de capital; terá sido a gestão mais ineficaz? E se estes estivessem perante uma diminuição da sua taxa de retorno? Para se poder responder concretamente a esta pergunta ter-se-ia de comparar 


\section{pontěditora}

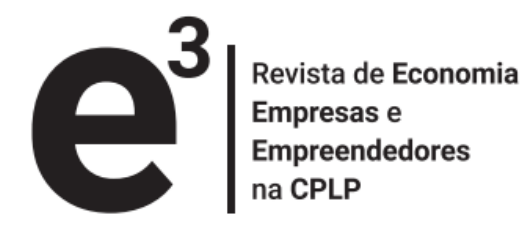

este quociente com outras taxas de retorno, existentes no mercado, e avaliar se a entidade está ou não a gerar uma rendibilidade superior ou inferior a essas outras alternativas, decerto um assunto para estudos futuros.

Relativamente à Rendibilidade do Ativo e, apresentando a entidade em estudo, atipicamente, um resultado antes de imposto negativo contra o resultado líquido positivo, este indicador reflete uma melhoria. No entanto a rendibilidade operacional das vendas manteve-se inalterada. Também a rotação do ativo apresenta uma diminuição face ao valor apurado antes da revalorização, indicando que para cada euro investido corresponderia menos euros vendidos.

De modo a se poder concluir este artigo, uma alusão às limitações deste estudo, que por ser um estudo de experimentação de uma única empresa, o resultado dele extraído não pode ser extrapolado para outras empresas em condições idênticas, sem que um estudo semelhante seja efetuado.

\section{REFERÊNCIAS}

Andrade, M.E., Silva, D.M. \& Malaquias, R.F. (2013). Escolhas contábeis em propriedades para investimento. Revista Universo Contábil, 9(3), 22-37. doi:10.4270/ruc.2013320

Carmo, H., \& Ferreira, M. M. (2008). Metodologia da Investigação - Guia para AutoApendizagem. (2 Edição ed.). Lisboa: Universidade Aberta.

Carqueja, H. (1995). Pequenos...Grandes Problemas?. VII. Justo Valor o que é? Jornal Técnico de Contas e Empresas, 354, p. 70 e 71.

Costa, T., Silva. A.H. \& Laurencel, L. (2013). Escolha de práticas contábeis: um estudo sobre propriedades para investimento em empresas brasileiras não financeiras de capital aberto. Revista da Contabilidade e Organizações 18 (2013) 25-36. DOI: http://dx.doi.org/10.11606/rco.v7i18.55429

Doná, A. L., Marques, K. C., Moribe, A., \& Hercos Junior, J. (2015). Fatores determinantes do conteúdo divulgado no relatório de administração de empresas brasileiras. Revista Universo Contábil, 11(4), 82-106. doi:10.4270/ruc.2015433

Ferreira, R. F. (1998). O Justo (!) Valor. Revisores \& Empresa - Revista da Câmara dos Revisores Oficiais de Contas, (1), 22-24. 


\section{pontěditora}

Iudícibus, S. \& Martins, E. (2007). Uma investigação e uma proposição sobre o conceito e o uso do valor justo. Revista Contabilidade \& Finanças, 18(spe), 09-18.

Neves, J. C. (2012). Análise e Relato Financeiro - Uma Visão Integrada de Gestão. (5 ed.). Alfragide: Texto Editores, $\mathrm{Ld}^{\mathrm{a}}$.

Pardal, S., \& Lobo, C. B. (2011). Património Imobiliário - referências para a avaliação. Coimbra: Edições Almedina, S.A.

Pinto, M.J., Martins, V.A. \& Mendes da Silva, D. (2015). Escolhas Contábeis: o Caso Brasileiro das Propriedades para Investimento. Revista Contabilidade \& Finanças, 26(69), 274-289. DOI: 10.1590/1808-057x201500580

Silva, E. S. (2004). Normas Internacionais de Contabilidade (NIC) Abordagem Teórica e Prática. Porto: Editora Vida Económica.

Souza, F.E., Botinha, R.A., Silva, P.R. \& Lemes, S. (2015). A Comparabilidade das Escolhas Contábeis na Avaliação Posterior de Propriedades para Investimento: Uma Análise das Companhias Abertas Brasileiras e Portuguesas. Revista Contabilidade \& Finanças, 26(68), 154-166. DOI: 10.1590/1808-057x201500580

Tavares, F. (2011). Avaliação imobiliária: entre a ciência da avaliação e a arte da apreciação. Tese de Doutoramento, Departamento de Economia, Gestão e Engenharia Industrial, Universidade de Aveiro, Aveiro.

Tavares, F., Pereira, E., \& Moreira, A. C. (2009). Avaliação imobiliária pelo método comparativo na óptica do avaliador. Economia Global e Gestão, 14(3), 111-128.

\section{(c) $)$ EY-NC-SA}

O trabalho $\mathbf{e}^{3}$ - Revista de Economia, Empresas e Empreendedores na CPLP está licenciado com uma Licença Creative Commons - Atribuição-NãoComercial-Compartilha Igual 4.0 Internacional. 


\title{
Pesquisa de Clima Organizacional: um estudo de caso
}

\author{
Research of Ognanizational Climate: a case study
}

\author{
Mayara Alexandre ${ }^{1}$ \\ ${ }^{1}$ E-mail: $\underline{\text { maiaraalexandre15@ hotmail.com }}$
}

\begin{abstract}
Resumo: O mundo das organizações está cada vez mais competitivo. As empresas precisam ser resilientes, buscando factores que as diferenciem dos seus concorrentes. $\mathrm{O}$ factor humano é uma ferramenta poderosa nas mãos de gestores que tenham a capacidade de lidar com pessoas e de transformá-las em parte da sua estratégia no alcance dos objetivos organizacionais. O gestor deve atentar para as variáveis do ambiente interno e externo da empresa e como os seus colaboradores irão reagir a estas interações. Estas mudanças ambientais podem afetar positiva ou negativamente o desempenho individual de cada colaborador e, consequentemente, toda a equipa. A Pesquisa de Clima Organizacional mensura factores que influenciam no clima e avalia os resultados de forma a investigar as suas origens. Este trabalho irá analisar a ingerência do ambiente organizacional nos seus colaboradores e como o clima organizacional pode interferir nos seus comportamento e na motivação pessoal e profissional. Será aplicado um questionário de abordagem descritiva para avaliar os resultados da Pesquisa de Clima Organizacional.
\end{abstract}

Palavras-chave: Comportamento Organizacional; Clima Organizacional; Pesquisa de Clima Organizacional.

\begin{abstract}
The world of organizations is increasingly competitive. Companies need to be resilient, looking for factors that set them apart from their competitors. The human factor is a powerful tool in the hands of managers who have the ability to deal with people and turn them into part of their strategy in achieving organizational goals. The manager must pay attention to the internal and external environment variables of the company and how its employees will react to these interactions. These environmental changes can positively or negatively affect the individual performance of each employee and, consequently, the entire team. The Organizational Climate Survey measures factors that influence the climate and evaluates the results in order to investigate their origins. This work will analyze the interference of the organizational environment in its employees, and how the organizational climate can interfere in their behavior and personal and professional motivation. A descriptive approach will be applied to evaluate the results of the Organizational Climate Survey.
\end{abstract}

Keywords: Organizational Behavior; Organizational Climate; Organizational Weather Research. 


\section{pontěditora}

\section{INTRODUÇÃO}

Adaptar-se a um ambiente organizacional competitivo e em constante mudança é um desafio cada vez mais atual na administração moderna. Segundo Moreira (2008), apesar destas mudanças antecederem o progresso, a transformação na forma e/ou estado das coisas, seja para melhor ou não, afetam diretamente as pessoas e por consequência o seu comportamento.

Para Moreira (2008, p. 8), "as mudanças decorrentes dos fatores externos e de alguns fatores internos da empresa afetam diretamente o comportamento dos trabalhadores de forma positiva ou negativa" e, com isso, o clima organizacional.

O clima da organização é um importante conceito para um gestor, porque é através do estabelecimento de um clima organizacional adequado que o gerente pode estabelecer as condições motivadoras no ambiente de trabalho. A eficácia da organização pode ser aumentada criando-se um clima organizacional que satisfaça ás necessidades dos membros da organização (MOREIRA, 2008, p. 19)

Como analisa Johann (2013), o clima organizacional demonstra o grau de satisfação dos colaboradores no ambiente de trabalho, que é indicado tanto por factores materiais quanto por factores emocionais que forma o ambiente de trabalho.

A empresa em estudo, é uma organização de médio porte, localizada na região noroeste de Belo Horizonte, Minas Gerais. É formada por três sócios e atua há mais de 30 anos no mercado médico-hospitalar, desenvolvendo um trabalho de propaganda médica, consultoria, distribuição e logística. Trabalha com divulgação e distribuição de produtos de grandes empresas, parceiras nacionais e multinacionais. A sua estrutura é aprovada e licenciada pela Agência Nacional de Vigilância Sanitária, a ANVISA e demais órgãos competentes.

A sua Missão consiste em divulgar e comercializar produtos e também tecnologias que agreguem valor à cadeia hospitalar. Já a sua visão é ser referência como uma organização com know-how na área hospitalar. Entre os seus valores, destaca-se por ser uma empresa que se preocupa com o bem estar dos seus colaboradores, através de políticas motivacionais, e que se orgulha em investir em pessoas. 


\section{pontěditora}

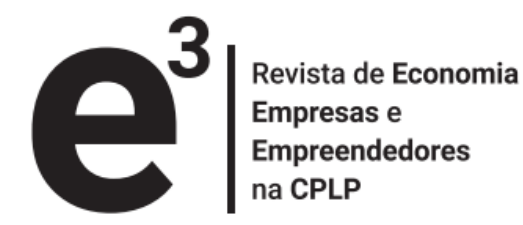

Para Moreira (2008), o estudo do clima organizacional permite identificar e promover ações de melhorias que subsidiam o equilíbrio entre a satisfação do colaborador e o desempenho que se espera da organização para que a mesma alcance os objetivos. Ainda segundo o autor acima, "através da pesquisa de clima organizacional, os colaboradores expressam suas opiniões, contribuem para melhoria do ambiente de trabalho". Assim, o problema deste estudo é: Qual a percepção dos funcionários internos da empresa em estudo sobre o clima organizacional de acordo com a Escala de Clima Organizacional (ECO)?

O objetivo geral deste estudo é identificar a perceção do clima organizacional dos funcionários internos da empresa pesquisada de acordo com a Escala de Clima Organizacional (ECO). Os objetivos específicos são:

- Identificar o perfil dos funcionários pesquisados;

- Identificar os cinco factores da escala ECO;

- Propor no final da pesquisa um plano de ação de melhorias.

Este estudo justifica-se pela relevância do tema e pela importância social e económica, pois, segundo Johann (2013), o clima organizacional é o que mensura a perceção dos colaboradores em relação à atmosfera emocional do ambiente de trabalho. Além disso, Luz (2010) pondera através da pesquisa de clima que as organizações podem avaliar e entender o que pensam e sentem os seus colaboradores, em relação às diferentes variáveis que afetam o clima, tais como: salário, trabalho, condições de segurança no trabalho, entre outras.

Tem relevância também para a empresa pesquisada porque através da elaboração da pesquisa organizacional, pretende-se elaborar um indicador que proporcione resultados para avaliar como as pessoas e organizações interagem, e como isso reflete nos resultados da empresa. Torna-se, assim, o factor humano um diferencial competitivo.

\section{REFERENCIAL TEÓRICO}

$\mathrm{Na}$ construção desse referencial foram pesquisados vários autores e selecionados os assuntos referente ao tema e problema pesquisado: Gestão de Pessoas; Cultura 


\section{pontěditora}

Organizacional; Clima Organizacional; Pesquisa de Clima Organizacional; Comportamento Organizacional.

\subsection{Gestão de Pessoas}

Para se entender as diretrizes e o conceito da pesquisa de clima organizacional precisamos primeiramente compreender o que é "organização", o que é "clima organizacional", e como influenciam os objetivos da empresa.

Segundo Spina, Gnoto e Pelacani (2012), “organização” é um sistema onde se olha para o futuro, é um sistema baseado nas decisões através de um olhar criativo e inovador. É de responsabilidade da mesma proporcionar aos seus colaboradores recompensas para motivá-los ao crescimento.

Já de acordo com Nascimento (2008), as organizações no futuro estarão voltadas para a missão e inovação, onde se busca demonstrar vantagem e novas estratégias para resistir a um ambiente externo em constante mudança.

A gestão de pessoas tornou-se mercado tecnológico e competitivo, a maior estratégia das empresas. Xavier (2006) afirma que, mesmo com todos estes avanços, a solução dos problemas e dos desafios organizacionais continua nas mãos dos colaboradores.

Xavier (2006) corrobora que, à medida que a organização entende e conhece melhor as expetativas e comportamentos do seu quadro de pessoal, ela poderá adotar medidas que auxiliem a prover um ambiente produtivo e para ajudar que todos se unam em prol de um objetivo maior, atingindo as metas da empresa.

Ainda segundo o autor acima, as mudanças rápidas na sociedade afetam pessoas e organizações em quatro aspetos:

- Económico: queda de vendas e/ou aumento de custos, devido ao surgimento de uma nova tecnologia. Afeta e empresa que venderá menos e os colaboradores que podem ser mandados embora como consequência.

- Financeiro: A empresa que vende menos terá problemas de caixa e o colaborador será afetado, pois poderá ter seu salário reduzido. 


\section{pontěditora}

- Operacional: Dificuldades operacionais ocorrem para adaptar a estas mudanças, por exemplo, corte de pessoal, mudanças na carga horária, etc.

- Psicossociais: Quando as pessoas começam a ficar tensas, sendo que com as dificuldades vêm os conflitos, desequilíbrio emocional, etc.

\subsection{Cultura Organizacional}

Siqueira (2008), diz que a Cultura Organizacional é o envolvimento dos colaboradores e da organização nos valores e filosofia da empresa. É o conjunto de ideologias e crenças que serve para resolver problemas de integração.

Ainda de acordo com o autor acima, a Cultura Organizacional manifesta-se em três diferentes aspetos:

- Artefatos visíveis: Arquitetura, modo de vestir, linguagem, tecnologia, entre outros. Tudo aquilo que é visível e de fácil observação.

- Valores: Comportamento justificativo para o modo de ser da organização.

- Pressupostos básicos: Crenças e perceções responsáveis sobre como os membros da organização se sentem e pensam em relação á mesma.

Basicamente, Siqueira (2008) indica que a cultura organizacional se manifesta através das pessoas da organização. O que torna o processo de cultura dentro de uma empresa possível é o facto de que as pessoas as transmitem e, através de sua percepção, tornam eficiente a sua disseminação para outros colaboradores.

Segundo Moreira (2008), a cultura expõe e determina quais serão as características da organização: "Identifica os aspectos que impactam positivamente e os obstáculos ao processo de desenvolvimento no universo empresarial em constante mudança" (MOREIRA, 2008, p.22).

Porém, Moreira (2008) acrescenta algumas características importantes na formação da cultura organizacional. São elas:

- Ritos e cerimónias;

$\mathrm{e}^{3}$ - Revista de Economia, Empresas e Empreendedores na CPLP | Volume 4 | Número 1 


\section{pontěditora}

- Histórias e mitos;

- Tabus;

- Heróis;

- Normas;

- Processos de comunicação.

A cultura organizacional pode ser compreendida como o comportamento da organização, ou seja, os valores, as normas, os processos, os ideais, a missão e os objetivos existentes na corporação. É a partir dela que se coloca ordem na empresa, é nela que os colaboradores irão se basear para desenvolverem suas normas de conduta e atividades e é através da cultura, também, que se construirá um ambiente de trabalho sadio. (MOREIRA, 2008, p. 23)

Ele afirma também que a Cultura Organizacional deriva do fundador da empresa, das suas filosofias e crenças, e que isto é transmitido para os demais colaboradores. Ainda de acordo com Moreira (2008), a cultura leva muito tempo para ser construída e as mudanças no clima de trabalho influenciam também na cultura organizacional que pode levar anos para chegar ao seu projeto final

Segundo Moreira (2008), os dirigentes têm muita influência na cultura organizacional e, portanto, no clima organizacional. Assim, é necessário que logo no processo seletivo seja disseminada a cultura organizacional, para que seja feita uma avaliação adequada do perfil do candidato, para avaliar se o mesmo irá se encaixar nos padrões culturais da empresa.

As empresas devem associar a cultura como forma de se manterem competitivas no mercado. Moreira (2008) afirma que ter vantagem competitiva é fundamental para conquistar novos clientes e atrair novos.

E como estratégia ter uma cultura organizacional saudável, que esteja de acordo com o que está acontecendo no mundo moderno, é fundamental para que a empresa planeie metas eficazes para o sucesso a longo prazo. 


\section{pontěditora}

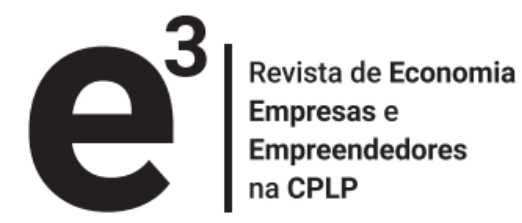

\subsection{Clima Organizacional}

De acordo com Siqueira (2008), para entender como o ambiente de trabalho e as suas constantes mudanças influenciam os seus colaboradores e o comportamento em relação a este ambiente, temos que falar de clima organizacional. Ainda de acordo com Siqueira (2008, p. 31), Clima Organizacional refere-se "a influências do ambiente interno de trabalho sobre o comportamento humano".

As organizações precisam compreender como os seus colaboradores interagem e percebem estas mudanças organizacionais, e como isso afeta o seu comportamento. Os colaboradores estão diariamente expostos a transformações e estímulos vindos das rápidas mudanças no ambiente externo da organização, tendo visões e reações diferentes a essas dinâmicas.

Não se deve confundir clima organizacional e avaliação de satisfação, esses se diferem conforme abaixo:

Clima organizacional é formado por percepções compartilhadas pelos trabalhadores. Na avaliação de satisfação verifica-se o quanto o empregado 'gosta ou não' de determinados aspectos do ambiente organizacional; na avaliação de clima organizacional verifica-se a percepção, a descrição da ausência ou presença destes aspectos. Portanto clima organizacional é uma variável da natureza cognitiva, enquanto satisfação no trabalho é uma atitude e, como tal, composta por elementos afetivos e cognitivos (SIQUEIRA, $2008 \mathrm{p}$. 32)

Moreira (2008) destaca que o clima organizacional não é palpável ou visto, mas pode ser constatado através da perceção.

O clima organizacional é um ambiente formado pelas pessoas da organização, provocando interações que interferem na motivação e comportamento deste grupo.

Clima organizacional e cultura organizacional são termos diferentes, mas que se complementam. Robbins (2009) certifica isso afirmando que cultura organizacional é "um sistema de valores compartilhado pelos membros que diferencia uma organização das demais". 


\section{pontěditora}

Luz (2007) ressalta que o Clima organizacional é um reflexo do ambiente. Dito isso, difere-se da cultura, pois enquanto o primeiro demonstra como é percebido o ambiente da empresa pelos colaboradores, o segundo demonstra como este ambiente vai ser construído, as suas regras padrão, etc.

Luz (2007, p. 13) descreve clima organizacional como "a atmosfera psicológica que envolve num dado momento a relação entre a empresa e seus funcionários".

\subsection{Pesquisa de Clima Organizacional}

Para Johann (2013), a pesquisa de clima organizacional deve ser usada como uma ferramenta de diagnóstico, pois através dela pode ser uma base de como os colaboradores estão percebendo a organização e sua dinâmica.

É necessário para o alcance dos objetivos organizacionais que todos os colaboradores entendam a importância das metas da empresa e estejam comprometidos a partilhar os valores, a missão e visão da empresa.

\subsection{Comportamento Organizacional}

Robbins (2009) ressalta a diferença entre comportamento e atitude. A atitude será uma pré-ação, ou seja, é aquilo que antecede o comportamento. Por sua vez, o comportamento é o reflexo da atitude. Para que a organização esteja preparada para os novos mercados, desafios, entre outros, a sua atitude em relação às mudanças deve ter em vista transformá-las em oportunidades.

Robbins (2009) destaca que o comportamento organizacional é, também, classificado como habilidades humanas dentro da organização, é o estudo do que fazem e como o comportamento humano afeta o seu desempenho na organização.

O comportamento Organizacional é um campo de estudos que investiga o impacto que indivíduos, grupos e a estrutura tem sobre o comportamento dentro das organizações com o propósito de utilizar este conhecimento para melhorar a eficácia organizacional. (ROBBINS, 2009 p. 6). 


\section{pontěditora}

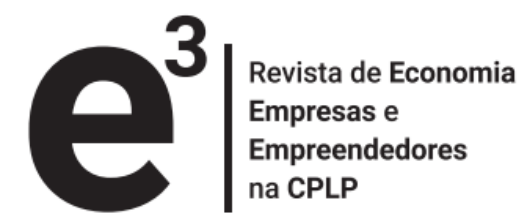

Robbins (2009) argumenta que, para os executivos, compreender o comportamento organizacional é de suma importância para que os mesmos possam se adaptar as rápidas mudanças do mundo globalizado e cada vez mais competitivo. O comportamento organizacional traz desafios, mas que se tornam oportunidades e soluções para estes novos cenários organizacionais.

Pode-se destacar, segundo Robbins (2009), que o estudo do comportamento organizacional proporcionará aos empresários a capacidade de manter a sua equipa de trabalho qualificada e comprometida, o que como consequência os tornará mais competitivos. Assim, torna-se necessário práticas de melhoria contínua e gestão da qualidade. Para isso, é necessário que os colaboradores passem por treinos e constantes avaliações que os tornem aptos para aprender novas habilidades.

Todas estas mudanças necessárias à organização não seriam possíveis sem a inclusão dos colaboradores, pois, além da força de trabalho para a execução destas mudanças, eles também se tornarão coparticipantes do planeamento.

Nascimento (2008) pondera, por sua vez, que o comportamento organizacional é influenciado pela cultura da empresa. E a cultura, por sua vez, é influenciada por factores educacionais, familiares, sociais, etc. Sendo assim, trabalhar com a diversidade é um papel desafiador para os novos gestores. Estes devem "criar uma cultura organizacional focada para promoção da liberdade de expressão e que fortaleça as relações, com uma contribuição efetiva na organização"(NASCIMENTO, 2008 p. 74).

Chiavenato (2014) pondera que o comportamento organizacional é o estudo dos indivíduos que compõem a organização e o seu ambiente, com o objetivo de analisar as variáveis que podem interferir no comportamento humano individual e que podem ter impacto no ambiente organizacional.

Ainda segundo o autor, para compreender o comportamento organizacional é preciso atentar dois aspetos: os superficiais e perceptíveis, e os profundos e imperceptíveis.

Dentre os aspetos visíveis pode-se citar: as estratégias e objetivos, políticas, tecnologia, estrutura, comando, etc. Já dentre os aspetos invisíveis estão: as atitudes, percepções, interações dos grupos informais e os conflitos interpessoais.

$\mathrm{e}^{3}$ - Revista de Economia, Empresas e Empreendedores na CPLP | Volume 4 | Número 1 


\title{
pontěditora
}

\begin{abstract}
Ademais, o CO se defronta com desafios importantes, como o nível de mudança no mundo e no ambiente dos negócios, nas características da força de trabalho que atua nas organizações, nas expectativas dos clientes e consumidores, nas próprias organizações, no comportamento dos dirigentes e gerentes $e$, sobretudo, no fato de que o conhecimento está se tornando progressivamente o principal fator de produção. Tudo isto torna o estudo da CO cada vez mais importante, tanto pata o sucesso organizacional quanto para o sucesso pessoal daqueles que lidam com organizações (CHIAVENATO, 2014, p. 19).
\end{abstract}

\section{METODOLOGIA}

A metodologia utilizada foi a pesquisa descritiva com um estudo de caso e o método quantitativo. Segundo Lakatos e Marconi (2003 p.155), “A pesquisa, portanto, é um procedimento formal, com método de pensamento reflexivo, que requer um tratamento científico e se constitui no caminho para conhecer a realidade ou para descobrir verdades parciais". Kauark, Manhães e Medeiros (2010) acrescentam que pesquisa é a busca por solução de algum problema. Seria produzir resposta para algo ou alguém.

Para Kauark, Manhães e Medeiros (2010), é importante classificar os tipos de pesquisa para que o pesquisador identifique os instrumentos e procedimentos para elaborar a sua investigação. Para Vergara (2006), a pesquisa pode ser classificada de duas formas: quanto aos fins e quanto aos meios. Quanto aos fins, a pesquisa feita neste trabalho é a descritiva, que procurou informações para as variáveis relacionadas à pesquisa de clima organizacional.

A modalidade de pesquisa descritiva, conseguiu mensurar os resultados por meio de questionário:

Pesquisa Descritiva: visa descrever as características de determinada população ou fenômeno, ou o estabelecimento de relações entre variáveis. Envolve o uso de técnicas padronizadas de coleta de dados: questionário e observação sistemática. Assume, em geral, a forma de Levantamento (KAUARK; MANHÃES; MEDEIROS; 2010, p. 28)

A pesquisa foi realizada na empresa já citada como instrumento de estudo. O questionário foi aplicado a 15 dos 23 colaboradores internos da empresa, pois não foi obrigatório que todos respondessem, tendo a adesão de $65 \%$ do universo pesquisado. Não foi necessária amostra. 


\section{pontěditora}

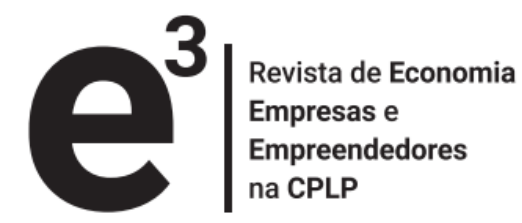

Os sujeitos deste trabalho foram os colaboradores internos, devido à facilidade de acesso do autor do estudo aos mesmos. Dito isso, este trabalho usou como padrão o critério de acessibilidade proposto por Vergara (2006).

A técnica utilizada foi um questionário, que para Kauark, Manhães e Medeiros (2010) é um instrumento de coleta de dados que é elaborado pelo pesquisador e é preenchido por quem ele está sendo aplicado. Deve-se atentar para uma linguagem simples e direta, de forma que o informante entenda com clareza as perguntas. Antes da aplicação do questionário deve ser feito um pré-teste para não haver erro e para que o aplicador possa corrigir possíveis erros.

Questionário é um instrumento de coleta de dados, constituído por uma série ordenada de perguntas, que devem ser respondidas por escrito e sem a presença do entrevistador. Em geral, o pesquisador envia o questionário ao informante, pelo correio ou por um portador; depois de preenchido, o pesquisado devolve-o do mesmo modo. Junto com o questionário deve-se enviar uma nota ou carta explicando a natureza da pesquisa, sua importância e a necessidade de obter respostas, tentando despertar o interesse do recebedor, no sentido de que ele preencha e devolva o questionário dentro de um prazo razoável (LAKATOS; MARCONI, 2003, p.201).

Foi aplicado um questionário aos colaboradores internos que aderiram à pesquisa: a Escala de clima organizacional - ECO. A análise de dados foi a quantitativa, traduzida em informações que foram classificadas e analisadas. "Requer o uso de recursos e de técnicas estatísticas (percentagem, média, moda, mediana, desvio-padrão, coeficiente de correlação, análise de regressão)" (KAUARK; MANHÃES; MEDEIROS, 2010, p. 26).

\section{RESULTADOS}

O questionário utilizado para mensurar o clima organizacional foi a Escala de Clima Organizacional (ECO) para que se pudesse avaliar a perceção dos colaboradores sobre o clima organizacional e as suas influências. A ECO foi aplicada de forma anónima, ou seja, não foi revelada a identificação dos funcionários participantes.

Segundo Martins (2008), a ECO é uma escala que possui o objetivo de avaliar e mensurar a visão do funcionário sobre o clima organizacional presente na instituição que ele desenvolve as suas atividades. A escala final validada, que foi utilizada na 


\section{pontěditora}

pesquisa, é composta por 63 itens de avaliação onde o colaborador tinha as seguintes opções: 1 - Discordo totalmente; 2 - Discordo; 3 - Nem concordo, nem discordo; 4 Concordo; 5 - Concordo Totalmente; que estão divididos em 5 blocos de questionamentos, a fim de levantar dados sobre 5 factores, são eles: Factor 1, com 21 itens (Apoio da chefia e da organização); Factor 2, com 13 itens (Recompensa); Factor 3, com 13 itens (Conforto físico); Factor 4, com 9 tens (Controle e pressão); e Factor 5, com 7 itens (Coesão entre colegas). A ECO: Escala de Clima Organizacional é compostas por 5 factores e a análise de dados também foi feita por factor. Assim, obteve-se uma média factorial para cada um dos cinco factores.

O resultado foi obtido somando-se os valores marcados pelos colaboradores em cada item e dividindo-se pelo total de itens, ou seja:

Para o Fator 1, apoio da chefia e da organização, somam-se os valores das respostas aos itens 1 até o 21 e divide-se o resultado por 21. Depois, somam-se as médias de cada respondente em cada fator e divide-se pelo número de respondentes e assim sucessivamente. Os resultados das médias fatoriais deverão ser sempre um número entre 1 e 5 que é a amplitude da escala de respostas. (MOREIRA, 2008, p. 20).

O quadro 1 mostra os factores de avaliação, bem como suas definições, e quais são os itens a quais eles se referem no questionário:

Quadro 1 - Denominações, definições e itens integrantes da ECO

\begin{tabular}{|l|l|l|}
\hline DENOMINAÇÕES & DEFINIÇÕES & ITENS \\
\hline Apoio da chefia e da & $\begin{array}{l}\text { Suporte afetivo, estrutural e operacional da } \\
\text { chefia e da organização fornecido aos } \\
\text { empregados no desempenho diário de suas } \\
\text { atividades no trabalho. }\end{array}$ & 1 ao 21 \\
\hline Recompensa & $\begin{array}{l}\text { Diversas formas de recompensa usadas pela } \\
\text { empresa para premiar a qualidade, a } \\
\text { produtividade, o esforço e o desempenho do } \\
\text { trabalhador. }\end{array}$ & $\begin{array}{l}22 \text { ao } \\
\text { argado }\end{array}$ \\
\hline
\end{tabular}

$\mathrm{e}^{3}$ - Revista de Economia, Empresas e Empreendedores na CPLP | Volume 4 | Número 1 


\begin{tabular}{|l|l|l|}
\hline Conforto físico & $\begin{array}{l}\text { Ambiente físico, segurança e conforto } \\
\text { proporcionados pela empresa aos } \\
\text { empregados. }\end{array}$ & $\begin{array}{l}35 \text { ao } \\
47\end{array}$ \\
\hline Controle/pressão & $\begin{array}{l}\text { Controlo e pressão exercidos pela empresa e } \\
\text { pelos supervisores sobre o comportamento e } \\
\text { desempenho dos empregados. }\end{array}$ & $\begin{array}{l}48 \text { ao } \\
56\end{array}$ \\
\hline Coesão entre colegas & $\begin{array}{l}\text { União, vínculos e colaboração entre os } \\
\text { colegas de trabalho. }\end{array}$ & $\begin{array}{l}57 \text { ao } \\
63\end{array}$ \\
\hline
\end{tabular}

Fonte: SIQUEIRA (2008, p. 35)

Gráfico 1 - Escala do Clima Organizacional por factores

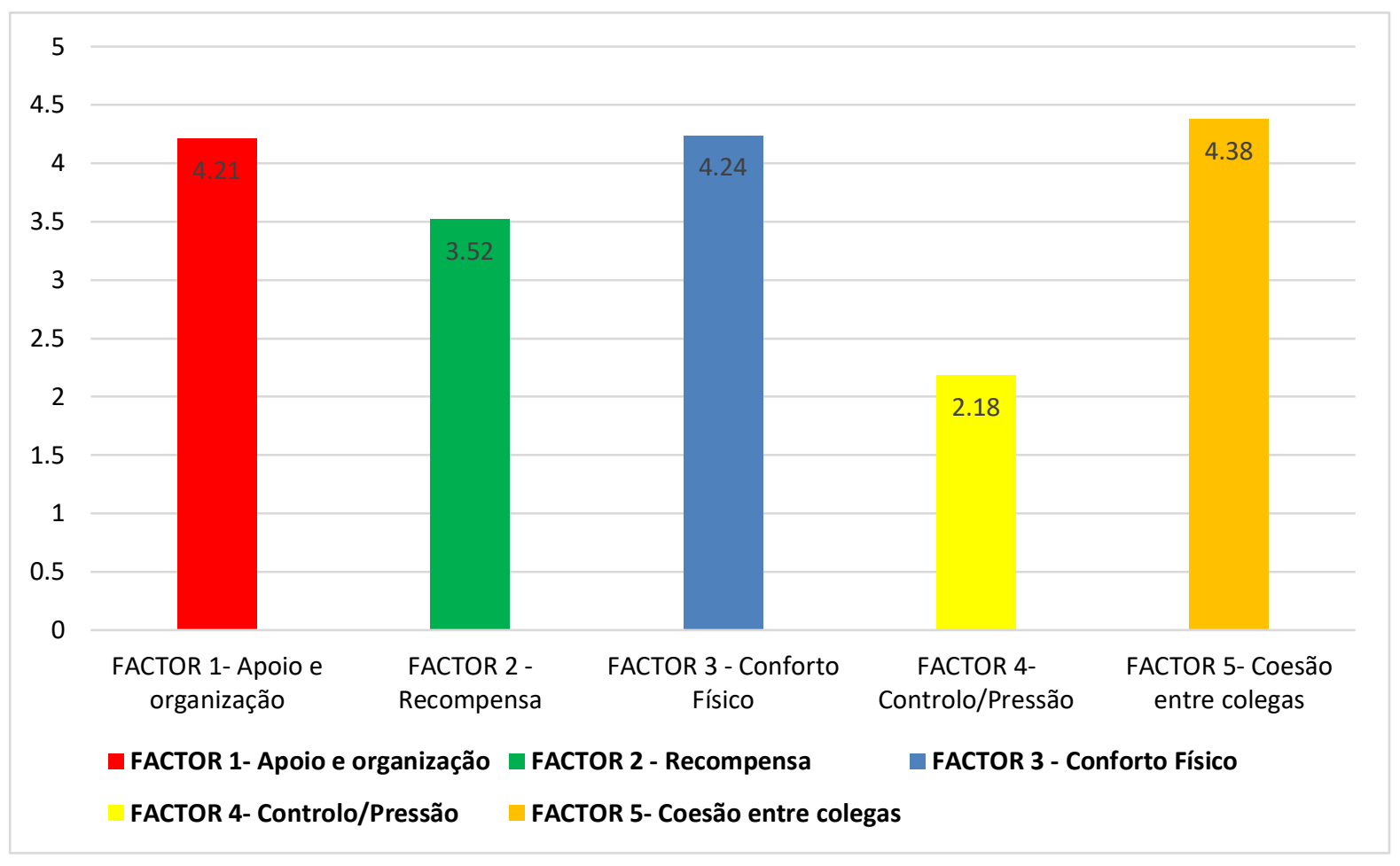

Fonte: Dados da pesquisa (2017)

Factor 1 - Apoio da chefia e da organização: buscou-se analisar o suporte afetivo, estrutural e operacional da organização e da direção e chefia, oferecido aos colaboradores para que os mesmos desempenhem as suas funções e atividades diárias 


\section{pontěditora}

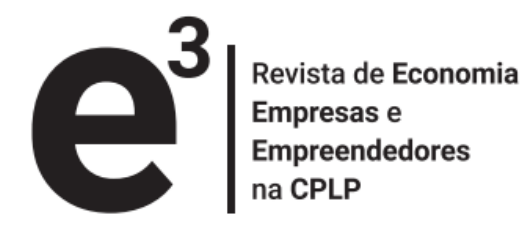

com eficiência e eficácia. Neste quesito, a empresa estudada apresentou um resultado muito satisfatório, alcançando a média de 4,21, onde 5,00 seria nota máxima. Portanto, a perceção dos colaboradores internos sobre o factor "Apoio da chefia e da organização" é de que eles têm um clima neste quesito sustentável para realizar as suas demandas e estão confortáveis em relação ao suporte recebido.

Factor 2 - Recompensa: neste factor analisou-se as formas com que a organização recompensa os seus colaboradores, de forma premiá-los pela qualidade, produtividade e esforço para desempenhar as suas funções. A empresa apresentou, também neste quesito, um resultado satisfatório, alcançando a média 3,52, onde 5 seria a nota máxima. Porém, observou-se que neste factor os colaboradores não estão com um nível de satisfação tão elevado quanto no factor acima. Notou-se que a sua percepção sobre as recompensas deve ser um factor que talvez necessite de atenção por parte da organização.

Factor 3 - Conforto físico: neste quesito analisou-se o ambiente físico, segurança e conforto que a empresa proporciona aos seus colaboradores. A empresa apresentou um resultado muito satisfatório, alcançando a média 4,24, onde 5 seria a nota máxima. Isso apontou que as dependências da organização estão de acordo com expetativa dos seus colaboradores e que eles se sentem confortáveis no seu ambiente de trabalho.

Factor 4 - Controlo/Pressão: analisou-se o controlo e pressão exercidos pela direção e supervisão sobre os colaboradores, comportamento e desempenho. A empresa apresentou um resultado muito satisfatório, pois, ao contrário dos quesitos acima, neste factor quanto menor o resultado demonstra que há um bom clima no ambiente de trabalho, onde não há demasiado abuso de pressão e controlo sobre os colaboradores. A empresa obteve média de 2,18 neste factor.

Factor 5 - Coesão entre os colegas: analisou-se a união, vínculos e colaboração entre os colegas de trabalho. A empresa apresentou um resultado muito satisfatório neste quesito, alcançando média de 4,38, onde 5 seria a nota máxima. A perceção dos colaboradores em relação aos seus colegas de trabalho é excelente. Percebeu-se que nesta empresa há um bom relacionamento entre os mesmos e isso aponta para um bom clima organizacional neste factor.

$\mathrm{e}^{3}$ - Revista de Economia, Empresas e Empreendedores na CPLP | Volume 4 | Número 1 


\section{pontěditora}

\section{CONSIDERAÇÕES FINAIS}

Após os resultados apresentados, conclui-se que os objetivos foram alcançados e constatou-se que a pesquisa de clima organizacional, utilizando a Escala de Clima Organizacional (ECO), é uma ferramenta valiosa para a compreensão das relações no ambiente organizacional e também no cenário atual de gestão com tantas turbulências económicas e tecnológicas.

Pode-se avaliar que a empresa apresenta um bom clima organizacional, a percepção dos colaboradores sobre a organização em seus múltiplos factores de clima como: apoio da chefia, conforto físico, controlo e pressão, e coesão entre os colegas foi muito satisfatório. Isso aponta que a empresa quer que os seus colaboradores sejam de facto seus parceiros nos alcances dos seus objetivos e se preocupa com o bem estar físico e emocional. Constatou-se na empresa pesquisada que o clima organizacional é ótimo sob o ponto de vista dos colaboradores internos, padrão que demonstra a qualidade da empresa no zelo pelas pessoas e no investimento interpessoal.

Observou-se que a limitação encontrada na pesquisa foi a resistência em se responder a algumas questões relacionadas à recompensa, onde alguns optaram em responder que "nem concordam e nem discordam", não expressando totalmente a sua opinião.

Após a análise dos resultados obtidos, notou-se que o quesito "recompensa" foi o único em que houve um resultado apenas satisfatório, não que esteja insuficiente, pois não influenciou consideravelmente na escala do clima. Mas seria um factor de atenção, pois, ele pode gerar não apenas insatisfação, mas criar um desconforto emocional nos colaboradores, mesmo que existam outros factores que compensem este desgaste.

Como proposta, sugere-se que a empresa adote um programa de recompensas flexível onde, por exemplo, o colaborador que for premiado pela sua qualidade e produtividade possa escolher, entre as opções propostas pela empresa, um pacote de benefício que melhor atenda a sua necessidade.

Para trabalhos futuros, sugere-se aos académicos de administração que continuem a pesquisar sobre o clima organizacional e a sua influência emocional e no desempenho dos colaboradores. 


\section{pontěditora}

\section{REFERÊNCIAS}

CHIAVENATO, Idalberto. Comportamento Organizacional: a dinâmica do sucesso nas organizações. 3. ed. Barueri: Manole, 2014.

JOHAN, Silvio. Comportamento Organizacional. São Paulo: Saraiva, 2013.

KAUARK, Fabiana; MANHÃES, Fernanda Castro; MEDEIROS, Carlos Henrique. Metodologia da Pesquisa: Um guia prático. Itabuna: Via Litterarum, 2010.

LAKATOS, Eva Maria; MARCONI, Marina de Andrade. Fundamentos de metodologia científica. 5. ed. São Paulo: Atlas, 2003.

LUZ, Ricardo. Gestão de clima organizacional. Rio de Janeiro:Qualitymark, 2007.

LUZ, Ricardo. Gestão do clima organizacional. Rio de Janeiro: Qualitymark, 2010.

MOREIRA, Ellen Gongorra. Clima organizacional. Curitiba: IESDE Brasil S.A., 2008.

NASCIMENTO, Eunice. Comportamento Organizacional. Curitiba: IESDE Brasil S.A, 2008.

ROBBINS, Sepen. Comportamento Organizacional. 11. ed. São Paulo: Person Prentice Hall, 2009.

SIQUEIRA, Mirlene Maria Matias, Medidas do comportamento organizacional: Ferramentas de diagnósticos e de gestão. Porto Alegre: ARTMED, 2008.

SPINA, Afonso; GNOTO, Gilberto; PELACANI, Maria Inez. Psicologia das Organizações. Curitiba: IESDE Brasil S.A, 2012.

VERGARA, S. C. Projetos e Relatórios de Pesquisa em Administração. 7. ed. SãoPaulo: Atlas, 2006.

XAVIER, Ricardo. Gestão de Pessoas na prática. São Paulo: Gente, 2006.

\section{(cc) EY-NC-SA}

O trabalho $\mathbf{e}^{3}$ - Revista de Economia, Empresas e Empreendedores na CPLP está licenciado com uma Licença Creative Commons - Atribuição-NãoComercial-Compartilha Igual 4.0 Internacional.

$\mathrm{e}^{3}$ - Revista de Economia, Empresas e Empreendedores na CPLP | Volume 4 | Número 1 


\title{
Decisões de financiamento bancário por parte da banca angolana: o caso do Banco de Poupança e Crédito
}

\author{
Bank financing decisions by Angolan banks: the case of Banco de Poupança e Crédito
}

Benedito Manuel ${ }^{1}$; Fernando Oliveira Tavares²; Luís Pacheco ${ }^{3}$.

\author{
${ }^{1}$ E-mail: benedito_manuel@hotmail.com \\ FE - Universidade Katyavala Bwila \\ (Benguela) \\ ${ }^{2}$ E-mail: ftavares @ upt.pt \\ Universidade Portucalense \\ ${ }^{3}$ E-mail: luisp@ @upt.pt \\ Universidade Portucalense
}

Resumo: Este trabalho tem como objetivo realizar um estudo sobre as ferramentas e técnicas usadas pelo Banco de Poupança e Crédito na análise e avaliação de projetos de investimento dos seus mutuários. Para a prossecução deste objetivo fez-se a comparação dos seus processos de decisão em relação aos apresentados na literatura científica, de modo acompreender a problemática do risco de crédito e do crédito mal parado do banco. A investigação conclui que por se tratar de um banco público, este vê-se forçado a apoiar projetos que de outra forma não seriam aceites. Também se verificou que uma parte do crédito em incumprimento do banco tem origem em clientes alanacados por serviços prestados ao Estado, faltando ao banco exigir as devidas garantias reais ou a aplicação de seguros de crédito. Conclui-se que o problema do banco identifica-se com os decorrentes da informação assimétrica, nomeadamente a seleção adversa e o risco moral.

Palavras-chave: Análise de Investimentos; Métodos de Análise e Avaliação de Projetos de Investimento; Sistema Financeiro Angolano; Banco de Poupança e Crédito.

\begin{abstract}
This paper aims to carry out a study about the tools and techniques used by the Savings and Credit Bank in the analysis and evaluation of investment projects of its borrowers. In order to achieve this objective, a comparison between its decision-making processes and the ones presented in the scientific literature was carried out, to be able to understand the problem of credit risk and bad credit standing of the bank. The investigation concludes that because it is a public bank, it is forced to support projects that would otherwise not be accepted. It has also been found that a portion of the credit in default of the bank originates in clients liable for services rendered to the State, lacking the bank to demand the proper guarantees or the application of credit insurance. It is concluded that the bank problem relates to those arising from asymmetric information, namely adverse selection and moral risk.
\end{abstract}

Keywords: Analysis of Investments; Methods of Analysis and Evaluation of Investment Projects; Angolan Financial System; Banco de Poupança e Crédito 


\section{pontěditora}

\section{Introdução}

Um investimento é uma aplicação de fundos escassos que geram rendimentos durante certo tempo, de forma a maximizar a riqueza da empresa. Segundo Barros (2007), o projeto de investimento é um conceito entendido em duas vertentes: enquanto plano (intenção) de investimento e enquanto estudo (processo escrito) da intenção do investimento (negócio).

Perante a intenção de investimento, considera-se que as duas vertentes são equivalentes, sendo reunidas num dossiê do projeto de investimento. Segundo Marques (1998), enquanto plano de investimento o projeto é uma proposta de aplicação de recursos escassos que possuem aplicações alternativas a um negócio, do qual se espera gerar rendimentos futuros durante determinado tempo, capazes de remunerar a aplicação de recursos.

O objetivo deste trabalho é realizar um estudo sobre as ferramentas e técnicas que o Banco de Poupança e Crédito (BPC) aplica na análise e avaliação de projetos de investimento dos seus mutuários, mediante a comparação dos seus processos com os apresentados na literatura científica, com vista a uma melhor forma de lidar com o risco de crédito e a problemática do crédito mal parado.

Num ambiente ainda de grande fragilidade económica, nascia a 24 de janeiro de 1956 o Banco Comercial de Angola (BCA), com um capital social detido em 50\% pelo Banco Português do Atlântico, enquanto a parte restante era repartida por outros fundadores, entre os quais Cupertino de Miranda, que presidia ao seu Conselho de Administração e Manuel Vinhas, do Grupo Cuca (BPC, 2011). A criação daquele banco tinha como fundamento a realização de operações bancárias que, de acordo com os seus Estatutos, concentrar-se-iam no crédito agrícola e industrial. No entanto, ao longo dos anos, o Banco assumiu distintas denominações de acordo com as diferentes fases da evolução do sistema financeiro angolano.

A mudança da situação política em Portugal, em 1974, e o alcançar da independência nacional levaram as autoridades angolanas a intervir para evitar o desmoronamento de todo o sistema monetário e financeiro, através da célebre operação desencadeada a 14 de agosto de 1976, que ficou conhecida como a "Tomada da Banca". Foram confiscados os ativos e passivos do Banco de Angola e criado o Banco Nacional de Angola (BNA), através da Lei n. ${ }^{\circ}$ 69/76 de 5 de novembro, e a Lei n. ${ }^{\text {o }}$ 70/76 criou o Banco Popular de 


\section{pontěditora}

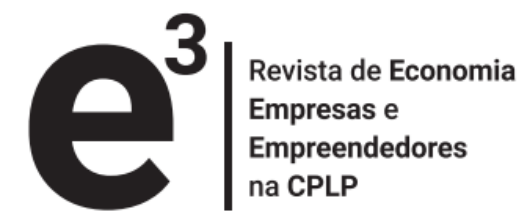

Angola. A partir de 1991, o Governo iniciou a implementação da reforma do setor financeiro e aprovou a legislação que criou um sistema bancário de dois níveis, nomeadamente através da Lei n. ${ }^{\circ}$ 4/91 - Lei Orgânica do Banco Nacional de Angola - e da Lei n. ${ }^{\circ}$ 5/91 - Lei das Instituições Financeiras, que dava fim ao monopólio do Estado no setor financeiro.

A nova Lei Orgânica do BNA considera-o como Banco Central de um sistema bancário de dois níveis, consagrado como autoridade monetária, agente de autoridade cambial e separado das funções comerciais, enquanto a Lei das Instituições Financeiras veio regular o exercício de funções de crédito e a constituição de outras instituições de capitais privados, nacionais ou estrangeiras.

O antigo Banco Popular de Angola passou a Banco de Poupança e Crédito (BPC) através do Decreto n. ${ }^{\circ}$ 47/91, tendo como únicos acionistas o Estado e o Instituto Nacional de Segurança Social. O sistema bancário nacional passou então a ser composto, para além do BNA, por mais dois bancos comerciais constituídos sob forma de sociedades anónimas de capitais públicos - o Banco de Poupança e Crédito (BPC) e o Banco de Comércio e Indústria (BCI).

Atualmente, o BPC é um dos maiores bancos comerciais do país, com uma rede de 406 balcões, espalhada por todo o território nacional e um número significativo de colaboradores. O Banco oferece uma gama variada de produtos e serviços, de forma responsável, a clientes institucionais, empresas e particulares e assume-se como parceiro social do Estado nos programas de aumento da capacidade produtiva nacional, de regulação da vida económica e da melhoria da qualidade de vida das populações.

Como Banco de referência em Angola, a sua estratégia está sustentada por três elementos fundamentais: melhoramento contínuo dos serviços oferecidos; apoio das iniciativas públicas e privadas no domínio de investimento, sempre respeitando e compreendendo as necessidades dos clientes; desenvolvimento do sistema de informação, com uma excelente rede de balcões em todo o país.

O presente artigo está estruturado do seguinte modo: a secção seguinte descreve brevemente os principais riscos decorrentes da concessão de crédito por parte da banca e as técnicas de análise de risco. A terceira secção apresenta a metodologia do BPC relativamente aos processos de concessão de crédito, bem como caracteriza a situação atual do banco. Por último, são discutidas as conclusões e apresentadas algumas 
limitações do estudo.

\section{Revisão da literatura}

A relevância da análise de investimentos constitui o principal sustentáculo de decisões que condicionam de forma marcante a composição do ativo fixo e a estrutura de funcionamento de uma dada organização no médio e longo prazo (Souza e Neto, 2012). Segundo Soares et al. (2007), o projeto de investimento é composto pela sua descrição física (layout de unidades de produção ou de operação), considerações de natureza mercadológica, cronograma de implantação do empreendimento, descrição das fontes de financiamento, além dos seguintes dados: investimentos permanentes (imóveis, máquinas, instalações, etc.); investimento em capital para fundo de maneio (stocks, matérias-primas, subsidiárias, etc.); valor de venda ao longo do período de análise do projeto e valor dos gastos ao longo do período de análise do projeto. Para Albino, Tavares e Pacheco (2016) o projeto de investimento pressupõe uma sequência de estudos que visam verificar a sua viabilidade económico-financeira.

Em suma, o projeto de investimento, segundo Patah e Carvalho (2016), é definido como o conjunto de informações internas e/ou externas coletadas e processadas com objetivo de serem analisadas e, eventualmente, implantadas, resultando numa decisão de investimento.

\subsection{Riscos acautelados nas decisões de financiamento de projetos de investimento}

A utilização sobre os fundos mutuados pelo Banco está sujeita a diversos riscos de caráter sistemático, operacional e financeiro que urge identificar previamente. Segundo Tavares, Pacheco e Pires (2016) e Tavares, Pacheco e Almeida (2015), os riscos traduzem-se num determinado grau de incerteza associado à desejada capacidade de serviço da dívida da Empresa. Portanto, o analista deve procurar caracterizar o melhor possívelos riscos, o que lhe permitirá igualmente definir qual o tipo de controlo mais adequado ao acompanhamento dos créditos.

Os principais riscos que podem ser identificados no âmbito de qualquer análise de crédito empresarial são os seguintes: 


\section{pontěditora}

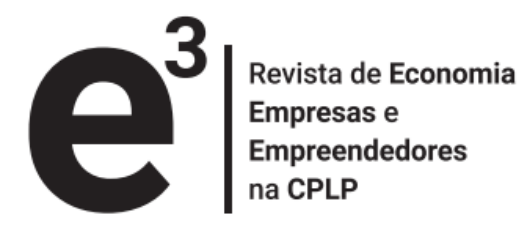

- Riscos macroeconómicos - caracterizado pelas políticas governamentais de caráter orçamental que podem afetar o poder de compra e a localização das unidades empresariais, o incentivo ao investimento, o impacto nas relações laborais e a cooperação internacional; a inflação que tem efeitos na competitividade a nível interno e internacional; a política cambial pela volatilidade e efeitos nas importações e exportações; a política do ambiente, com efeitos na comercialização dos produtos e custos não reprodutivos; assim como o risco do país pela convertibilidade cambial e embargos comerciais;

- Riscos setoriais - relacionados com o nível de maturidade e efeitos nas margens, desequilíbrio entre a oferta e a procura, barreiras à entrada de mercadorias do exterior, barreiras tecnológicas, políticas governamentais a nível setorial, protecionismo e o surgimento de produtos substitutos;

- Riscos de empresas - relacionado com o ciclo de conversão de ativos e a sua dinâmica; eventuais disfunções nos recursos humanos, características das instalações imobiliárias e dos equipamentos (e.g., contrato, estado de conservação, etc.); posição concorrencial no nível dos produtos e mercados, quotas e rivalidade; políticas de preços e estruturas de custos;

- Riscos de gestão - composição dos corpos sociais (idade, mandatos, equilíbrios de forças); experiência e historial de sucesso (espírito de inovação e capacidade reativa); relações entre o Banco e a gestão, níveis de sistemas de informação; níveis de definição estratégica e de objetivos; nível de motivação.

O Banco Nacional de Angola (BNA), enquanto autoridade de supervisão bancária do país, tem permanecido atento ao desenvolvimento do setor financeiro bancário e aos níveis de riscos incorporados, emitindo normativos que visam a implementação em Angola das melhores práticas internacionais do setor bancário. Um desses normativos é, precisamente, o Aviso n..$^{\circ}$ 2/2013, que impõe às instituições bancárias o estabelecimento de um sistema de gestão do risco que incorpore um conjunto integrado de políticas substanciado em procedimentos, limites, controlos e sistemas, com vista ao desenvolvimento de técnicas de análise de riscos mais adequadas para o estádio cada vez mais avançado de desenvolvimento do sistema financeiro angolano.

Os normativos do BNA representam grandes desafios para as instituições financeiras.

$\mathrm{e}^{3}$ - Revista de Economia, Empresas e Empreendedores na CPLP | Volume 4 | Número 1 


\section{pontěditora}

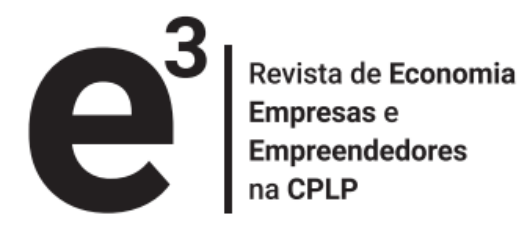

Esses normativos estão associados aos Acordos de Basileia, particularmente o segundo acordo (Basileia II), que define um conjunto de melhores práticas no desenvolvimento e utilização de técnicas de análise do risco de crédito, além dos processos de concessão, acompanhamento e recuperação de crédito.

Uma análise importante sobre o risco de crédito no setor bancário angolano é apresentada por KPMG (2013). Nesse relatório refere-se que o setor bancário angolano tem vindo a dar claros sinais de expansão, verificando-se assim um esforço assinalável por parte das instituições bancárias que procuram estar presentes em todas as Províncias, inclusivamente nas diferentes localidades. Essa expansão representa uma ousadia dos bancos, que procuram acompanhar o desenvolvimento da economia em geral. Porém, olhando para o agravamento do nível de crédito malparado que se verifica no setor, essa expansão pode implicar um relaxamento dos processos de avaliação de créditos por parte dos bancos e, por isso mesmo, um aumento da assunção do risco de crédito por parte da banca angolana.

\subsection{As técnicas de análise de risco dos projetos de investimento}

De acordo com a KPMG (2013), as técnicas de análise de risco podem ser genericamente divididas em modelos de rating e de scoring. Os modelos de rating são voltados para segmentos de Empresas e têm como suporte as demonstrações financeiras utilizadas com frequência (balanço, demonstração de resultados, orçamentos, etc.), das quais podem ser extraídos simples indicadores relacionados com a liquidez, solvabilidade, grau de endividamento, de autonomia financeira, etc. O modelo de rating pode ainda ser dividido em dois: modelos aplicacionais, "utilizados no âmbito da concessão de operações de crédito" e modelos comportamentais, "utilizados ao longo da vida do crédito". Estes são os modelos de PD (Probability of Default ou probabilidade de incumprimento), uma vez que o objetivo é a determinação da probabilidade de uma operação ou cliente entrar em incumprimento. Para os créditos que já se encontrem em incumprimento são utilizados modelos que permitem estimar as perdas associados a estas operações, geralmente denominados modelos de LGD (Loss Given Default ou perda em caso de incumprimento).

O modelo de scoring é, fundamentalmente, aplicável ao crédito a particulares e visa a análise objetiva do risco, procurando avaliar a capacidade e solvabilidade do cliente.

$\mathrm{e}^{3}$ - Revista de Economia, Empresas e Empreendedores na CPLP | Volume 4 | Número 1 
Estes modelos obedecem às mesmas regras que a avaliação de risco das empresas. É necessário conhecer a finalidade do crédito, o montante do crédito a conceder, o prazo de reembolso, a capacidade de reembolso do cliente. Este método de avaliação apresenta alguns factores negativos face à situação atual dos Bancos: é um procedimento moroso, não garante homogeneidade da decisão e está sujeito a variações de humor dos decisores, para além de uma forte componente subjetiva. Porém, o scoring é um método extremamente simples e usado sem recurso a tecnologias avançadas, nomeadamente com uma tabela de pontuação, que poderá ser utilizada por qualquer gestor de cliente.

A massificação da atividade bancária no domínio do crédito a particulares impõe que o Banco desenvolva ou adquira um aplicativo com rotinas de scoring automatizado para permitir o registo de um conjunto de factores de avaliação sobre o cliente e verificar se a pontuação final permite a aprovação da operação ou se a rejeita. Acreditamos que o sistema de scoring poderá tornar-se essencial num panorama de massificação da atividade bancária, sendo de utilização extremamente simples, não necessitando de conhecimentos específicos de qualquer tipo, somente tornando-se necessária a intervenção de um especialista de análise de risco, caso o sistema não aprove a operação e se pretenda uma reanálise pelo processo tradicional. Assim, o Banco poderá construir um sistema de scoring que reproduzirá a sua própria cultura e filosofia no domínio da concessão de crédito.

\subsection{Problema e perguntas de investigação}

Como referido anteriormente, o objetivo deste trabalho é realizar um estudo sobre as ferramentas e técnicas que o Banco de Poupança e Crédito aplica na análise e avaliação de projetos de investimento dos seus mutuários, mediante a comparação dos seus processos com os apresentados na literatura, com vista a uma melhor forma de lidar com o risco de crédito e a problemática do crédito mal parado.

O elevado nível de créditos mal parados verificados na banca angolana, em geral, e no Banco de Poupança e Crédito, em particular, indicia uma insuficiência ou deficiência das ferramentas e técnicas de análise e avaliação de projetos de investimento que o BPC utiliza atualmente, traduzida numa inadequação ao risco de crédito que o banco vem incorrendo nos últimos anos. 


\section{pontěditora}

Diante da realidade apresentada da economia e da banca angolana, levantam-se as seguintes perguntas de investigação:

- Como se desenvolve o processo de análise e avaliação de projetos de investimento no BPC?

- Que ferramentas e técnicas são utilizadas no processo de análise e avaliação de projetos de investimento do BPC?

- Que riscos são normalmente acautelados e que medidas são adotadas para mitigar esses riscos na seleção de pedidos de crédito ou financiamento bancário para fins de investimento?

- De entre as inúmeras ferramentas e técnicas de análise e avaliação de projetos de investimento apresentadas na literatura científica, quais podem ser melhor adaptadas à situação ou realidade concreta do BPC?

\section{Apresentação e discussão do estudo de caso}

\subsection{Princípios subjacentes à avaliação de projetos de investimento desenvolvida pelo BPC}

De acordo com o regulamento geral de crédito do Banco de Poupança e Crédito (BPC, 2014a), os princípios e regras gerais, que orientam o processo de análise e avaliação de projetos de investimento e de créditos em geral, obedecem às orientações ou requisitos definidos pelo Banco Nacional de Angola (BNA), bem como pela política de risco de crédito definida pelo Comité de Crédito e pelo Conselho de Administração do Banco, alinhada com os seus objetivos estratégicos e pelos limites de concentração fixados ou a fixar e pelos restantes normativos internos associados à atividade do Banco.

Assim, para a análise e avaliação de projetos de investimento, o BPC observa os seguintes princípios:

- Princípio da capacidade de endividamento e idoneidade do proponente do investimento;

- Princípio da avaliação de risco;

$\mathrm{e}^{3}$ - Revista de Economia, Empresas e Empreendedores na CPLP | Volume 4 | Número 1 


\section{pontěditora}

- Princípio da responsabilidade de gestão;

- Princípio do acompanhamento e recuperação de crédito;

- Princípio da concentração e diversificação da carteira de investimento.

O princípio da capacidade de endividamento e idoneidade do proponente do investimento recai sobre o seu comportamento, a situação conjuntural do setor de atividade em que se insere, a adequação da operação, prazos propostos, condições financeiras e demais condições, bem como a sua solidez financeira e capacidade de reembolso, incluindo, ainda, as garantias e colaterais exigidas pelo Banco.

O princípio da avaliação de risco tem por base a classificação do risco do proponente do projeto, de acordo com o segmento em que se insiram e os modelos de avaliação de risco que são desenvolvidos pela Direção de Risco Global. Um outro princípio subjacente à análise e avaliação de projetos de investimento no BPC é o princípio da rendibilidade associada ao risco, que leva em conta, entre outros, as condições financeiras associadas às operações de crédito ou financiamento em questão, o nível de provisionamento associado ao perfil de risco do cliente e suas operações e a identificação do nível de concentração das operações de crédito ou financiamento, face ao total de exposição de crédito do Banco e face à capacidade financeira de cada cliente. $\mathrm{O}$ princípio da responsabilidade de gestão substancia-se na intenção do BPC em fazer corresponder apenas um responsável pelo acompanhamento comercial do proponente de um projeto de investimento (seja um cliente individual ou um grupo económico), de forma a assegurar uma plenitude e consistência na identificação e análise das exposições e responsabilidades de crédito de forma agregada, possibilitando um maior rigor na análise e determinação do órgão e o escalão de apreciação e decisão das respetivas propostas de crédito.

Por fim, o princípio do acompanhamento e recuperação de crédito visa o desenvolvimento de procedimentos de acompanhamento das operações de crédito com o objetivo de deteção antecipada de sinais de deterioração das condições creditícias dos clientes, ao passo que o princípio da concentração e diversificação da carteira de investimento visa evitar a existência de uma concentração excessiva da carteira de crédito, seja sobre uma mesma entidade individual, grupo económico ou setor de atividade.

$\mathrm{e}^{3}$ - Revista de Economia, Empresas e Empreendedores na CPLP | Volume 4 | Número 1 


\section{pontěditora}

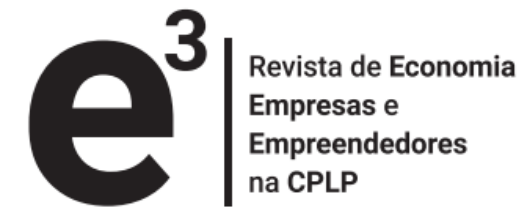

O Regulamento Geral de Crédito do Banco de Poupança e Crédito (BPC, 2014a) fornece inputs que permitem aferir o processo de análise e avaliação de projetos de investimento desenvolvido pelo BPC. Este processo enceta com uma proposta de financiamento que o proponente remete a um determinado balcão do banco, que é dirigido à área de Análise de Crédito, permitindo uma adequada e consciente tomada de decisão. O processo de análise é ainda complementado com o parecer da Direção de Risco Global, para as operações que pelo montante envolvido ou o grau de complexidade da operação assim o justifiquem, nomeadamente para as operações que são decididas ao nível do Comité de Crédito.

De acordo com o mesmo regulamento geral, na origem de crédito o relacionamento creditício com o cliente ou grupo económico deve ser efetuado preferencialmente através das agências, dependências, balcões, centros de empresas e centros de negócios do banco de opção, pelo que todo e qualquer pedido de crédito deverá ser apresentado através do gestor responsável pelo acompanhamento do cliente, sendo que excecionalmente os mesmos processos poderão ser encaminhados diretamente para as respetivas direções comerciais.

A área comercial articula com o cliente as condições para atribuição de uma linha de crédito/limite, ou de uma operação pontual, tendo em conta os preceitos constantes no regulamento geral de crédito, fichas de produtos ou respetivas normas de enquadramento, para apreciação e concretização.

Em todas as propostas de crédito é requerido o preenchimento e entrega de uma carta de solicitação, devidamente fundamentada através da indicação dos seguintes elementos: finalidade, montante, prazo, condições e preçários, modalidade, plano de reembolso, suficiência e liquidez das garantias e colaterais, rendibilidade do cliente e/ou grupo económico referente ao ano anterior, fonte de rendimento e capacidade de reembolso do empréstimo, tempo e tipo de relacionamento com o Banco. A carta de solicitação de crédito deverá ser acompanhada de toda a documentação que permita fundamentar a operação e conhecer a qualidade creditícia dos mutuários, assim como uma adequada e consciente tomada de decisão.

Na documentação para a concessão de crédito às empresas deverá ser apresentada com a carta-pedido a devida documentação certificada legalmente e/ou auditada e atualizada. Após ter-se dado entrada de toda a documentação exigida, segue todo um processo de 


\section{pontěditora}

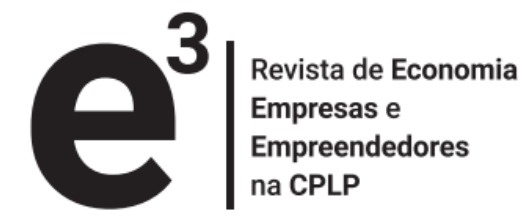

análise documental ou análise do próprio crédito, conforme descrito abaixo.

O Banco deve considerar, por regra, como situações inibidoras da concessão de crédito, os clientes que apresentem as seguintes situações: a não apresentação da documentação exigida ou ausência de atualização da mesma sempre que necessário e solicitado pelo Banco; crédito vencido no Banco ou no sistema bancário; sinais de alerta moderados, grave ou muito grave; dívidas ao Fisco e à Segurança Social e situação de incumprimento; processos judiciais e situações litigiosas, com repercussões negativas; irregularidade na movimentação das suas contas ou ocorrência de incidentes, não justificados nos últimos dois anos; desemprego ou incapacidade para gerar os meios necessários e suficientes para cobertura do serviço da dívida; incumprimento das cláusulas e acordos, negociados com o banco ou com sistema bancário.

$\mathrm{Na}$ apreciação de uma proposta de financiamento remetida ao BPC, a análise/avaliação do projeto radica em indicadores económico-financeiros deduzidos a partir das demonstrações financeiras (balanço e demonstração de resultados), caso a empresa já se encontre plenamente operacional. Caso a empresa ainda esteja a ser constituída, é solicitada a apresentação de um plano de negócio que comporte um estudo de viabilidade técnico-económica e financeira do projetos de investimento. Além disso, o BPC faz recurso a outras fontes de informação, designadamente a base de dados da Central de Informação e Risco de Crédito (CIRC), mantida pelo BNA, e listas de devedores ao Fisco e à Segurança Social. Além do recurso às fontes referidas, o processo de análise/avaliação de projetos do BPC também se apoia em modelos de rating/scoring, baseados em informações de natureza quantitativa e qualitativa dos clientes. Para tal, todos os clientes são classificados com um nível de risco determinado de acordo com estes modelos.

O objetivo da análise/avaliação é aferir a viabilidade económico-financeira e comercial da proposta apresentada, tendo em conta o enquadramento do negócio no contexto angolano, em geral, e o da zona geográfica onde se realizará o investimento, em especial. Também são tidas em conta as prioridades do governo e a estratégia comercial do Banco, factores que podem ter impacto na rendibilidade do investimento, no retorno da operação e, consequentemente, na decisão de crédito.

Assim, na análise/avaliação de projetos são tidos em consideração: ( $i$ ) o limite máximo de exposição por cliente ou grupo económico; (ii) o preçário da operação (taxa de juro e 


\section{pontěditora}

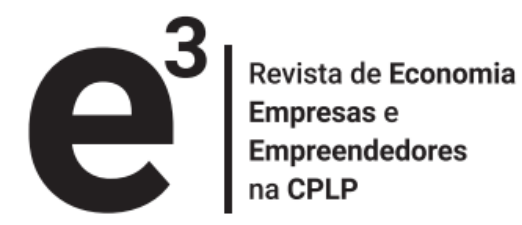

comissões); (iii) a rendibilidade da operação; (iv) as garantias mínimas e colaterais associadas ao crédito; (v) o prazo máximo da operação; o risco subjacente ao projeto; (vi) a capacidade de cumprimento do serviço da dívida por parte do proponente do projeto, medida através da taxa de esforço ou capacidade de endividamento do cliente.

No decorrer do processo, poderá ser agendada e realizada uma visita presencial aos clientes do segmento de Pequenas e Médias Empresas e Corporate com o objetivo de observar "in loco" a atividade do cliente e os objetivos do financiamento solicitado. $\mathrm{Na}$ sequência da mesma, deve ser elaborado um relatório de visita. Esta visita deverá ser assegurada pelas Direções Comerciais (gestor) com a responsabilidade de efetuar a gestão do respetivo cliente (BPC, 2014a).

\subsection{Principais riscos acautelados no processo de análise e avaliação de projetos de investimento do BPC}

O processo de tomada de decisão de financiamento do BPC baseia-se numa análise das características e perfil de cada proponente de projetos de investimento, a tipologia de operação, o nível e tipologia das garantias e colaterais apresentados pelo proponente, bem como as condições contratuais de taxa de juro e prazo associados.

No fundo, o que se quer dizer aqui é que no processo de análise e avaliação de projetos de investimento, desenvolvido pelo BPC, os riscos são acautelados e convenientemente identificados, isto é, consideram-se as origens desses riscos e as suas respetivas dimensões.

Assim, os riscos acautelados pelo BPC relacionam-se ao prazo da operação (curto, médio e longo prazos), ao cliente, à qualidade da gestão e outras características qualitativas, à situação económica e financeira histórica e previsional, ao setor de atividade, experiência no relacionamento com o Banco, existência de incidentes, relacionadas com a segurança do crédito (garantias e colaterais das operações de crédito - todas as garantias e colaterais associados às operações de crédito e os seus efeitos no perfil de risco das operações).

De entre os distintos riscos e origens identificadas acima, os de gestão são seguramente os mais preocupantes para o banco, desde já, pelas muitas dificuldades de gestão que as empresas em Angola apresentam, sobretudo pela insuficiência de competências de gestão empresarial.

$\mathrm{e}^{3}$ - Revista de Economia, Empresas e Empreendedores na CPLP | Volume 4 | Número 1 


\section{pontěditora}

O BPC tem em conta os factores de riscos relacionados com a composição dos corpos sociais, nomeadamente a idade dos gestores, as aptidões e conhecimento do ramo de negócio em que se inserem. Por outro lado, o banco também manifesta preocupação para com a experiência e o historial de sucesso, ou seja, avalia a capacidade de inovação e modernização, a capacidade dos gestores à reação rápida perante os desafios que vão surgindo ao longo do percurso do negócio. Também são tidas em conta as relações entre o banco e os gestores das empresas, concedendo-se financiamento a projetos de investimentos cujos proponente ou gestores gozem de boas relações com o banco, e rejeitando-se para aqueles proponentes cujas relações com o banco sejam más. No caso de empresas já plenamente operacionais, o banco acautela-se contra o nível de organização que essas ostentam em termos de produção de informações úteis, para permitir ao banco acompanhar os exercícios previsionais e controlar os seus orçamentos (vd. Quadro 1).

Quadro 1. Riscos acautelados na análise e avaliação de projetos no BPC

\section{Riscos de gestão}

Composição dos corpos sociais (idoneidade)

Experiência e historial de sucesso (espírito de inovação, capacidade reativa)

Relações entre o banco e a gestão (boas ou más)

Nível dos sistemas de informação de gestão (exercício previsional e controlo orçamental)

Nível de definição da estratégia e de objetivos (clareza e capacidade de prossecução)

Nível motivacional (tipo de comunicação interna, planeamento de carreiras, incentivos)

Fonte: BPC (2014a).

Do mesmo modo, e conforme se pode observar no Quadro 1, o Banco procura acautelar-se face a riscos que se prendem com o nível de definição de estratégias e de objetivos, isto é, se esses são definidos com clareza e exequibilidade. Por fim, há também uma enorme preocupação para com o nível de motivação dos gestores e colaboradores dos projetos, o que poderá perigar o sucesso do desenvolvimento do projeto.

Todos esses riscos são acautelados, visando-se colmatar outros riscos que podem surgir

$\mathrm{e}^{3}$ - Revista de Economia, Empresas e Empreendedores na CPLP | Volume 4 | Número 1 
após o financiamento (fruto do risco moral), nomeadamente o crédito mal parado, os cheques devolvidos, as ações e execuções judiciais, os pedidos de recuperação ao abrigo de legislação específica e falência.

\subsection{Medidas adotadas para a mitigação dos riscos}

Segundo o Regulamento Geral de Crédito do Banco de Poupança e Crédito (BPC, 2014a), caso o proponente do projeto não tenha meios para fornecer como garantia, o próprio investimento pode servir de garantia. Contudo, para esses casos é necessário haver uma enorme confiança do banco relativamente ao cliente, aferida com base numa série de informações recolhidas a respeito do proponente (históricos de crédito, visitas regulares ao desenvolvimento do projeto, análise da exequibilidade do projeto, etc.).

Para assegurar medidas de contenção ou mitigação de riscos, o BPC exige garantias (aval do Estado, garantia bancária, fiança, livrança e aval) e/ou colaterais (hipoteca, penhor financeiro, penhor mercantil, penhor de equipamento, consignação de rendimentos, leasing, seguro e reserva de propriedade) aceites pelo banco.

Assim, para a mitigação dos riscos inerentes aos processos de análise e avaliação de projetos de investimento submetidos ao BPC, o financiamento só é concedido após a devida formalização de todas as garantias e colaterais que tenham sido considerados na sua aprovação, sendo que no caso de garantias e/ou colaterais cuja formalização careça de um período mais alargado, o desembolso dos fundos associados à operação de crédito deverá ser proporcional à formalização das respetivas garantias e/ou colaterais. Além disso, em relação ao crédito colateralizado por imóveis, a avaliação dos ativos sobre os quais incide cada colateral deverá ser efetuada por peritos independentes e revistas nos termos definidos pela regulamentação do Banco Nacional de Angola.

\subsection{Políticas de gestão de riscos do BPC}

De acordo com Tavares, Pacheco e Pires (2016), em muitos países a gestão do risco tem assumido, cada vez mais, um papel de obrigatoriedade nas empresas, ao ponto de ser considerada uma ferramenta imprescindível, sem a qual se torna mais árduo o funcionamento da empresa. Com o BPC não é diferente. O Banco encontra-se atualmente a desenvolver o projeto "Transformação da Função Risco", que constitui um instrumento de gestão de riscos consubstanciado na adequação da sua gestão de riscos 


\section{pontěditora}

às melhores práticas nacionais e internacionais (e.g., Basileia) e dar resposta às novas exigências do mercado, focando em seis grandes pilares de atuação: Governação, Risco de Crédito, Risco Operacional, Riscos Financeiros, Informação de Suporte e Capacitação (BPC, 2014a).

No financiamento aos projetos de investimento e na concessão de crédito em geral, o BPC rege-se pelos Avisos n. ${ }^{\circ}$ 3/12 de 28 de março e n. ${ }^{\circ}$ 8/07 de 12 de setembro, ambos do Banco Nacional de Angola.

De acordo como relatório e contas de 2014 do Banco (BPC, 2014b), no ano de 2014, no âmbito do projeto de "Transformação da Função Risco", o Banco procedeu à atualização do regulamento geral de crédito, documento consultado neste trabalho. No final desse ano, deu-se início à atualização dos limites de competências para cada nível de decisão, assegurando a intervenção de, no mínimo, dois intervenientes no processo de aprovação das operações de crédito. No âmbito da recuperação de crédito, está em fase de conclusão um sistema de rating para a avaliação do risco de crédito do segmento de empresas.

Atualmente, a gestão dos riscos financeiros no BPC é partilhada pelas Direções de Risco Global, Tesouraria e Mercados e a de Planeamento e Controlo de Gestão, e baseia-se essencialmente na análise de indicadores de liquidez e solvabilidade. Contudo, o projeto de "Transformação da Função Risco" vem reforçar a segregação de funções no âmbito dos riscos financeiros, por via da operacionalização da intervenção da Direção de Risco Global na quantificação, avaliação e controlo destes riscos e da redefinição das responsabilidades de cada uma das áreas intervenientes" (BPC, 2014b).

O BPC produz, atualmente, relatórios periódicos para avaliar e monitorar a exposição aos riscos financeiros, tais como o risco de taxa de juro, de taxa de câmbio e de liquidez, por faixas de prazo residual dos ativos e passivos. Para o efeito, deu-se início ao desenvolvimento de uma ferramenta voltada à gestão de ativos e passivos, cuja implementação previa-se efetivar em 2015. Quanto ao risco cambial, o BPC centraliza a sua atuação dentro dos limites estabelecidos pelo Aviso n. ${ }^{\circ}$ 5/2010 do Banco Nacional de Angola.

O acompanhamento e monitorização da posição cambial do banco "são feitos através da análise do Relatório de Exposição Cambial, remetido numa base diária ao Banco Nacional de Angola, que engloba a exposição cambial das posições ativas e passivas nas 


\section{pontěditora}

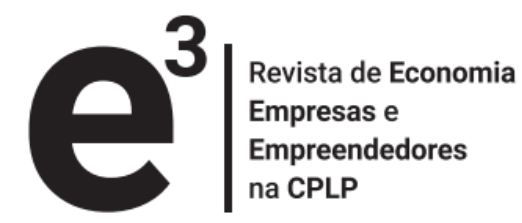

diversas moedas, bem como das rubricas extrapatrimoniais. Em 31 de dezembro de 2014, o BPC registava uma exposição cambial longa, igual a 4,0\% dos Fundos Próprios Regulamentares, dentro do limite de $20 \%$ estabelecido pelo órgão regulador”.

A gestão do risco operacional ainda se encontra dispersa em diferentes áreas do BPC, estando, no âmbito do projeto de "Transformação da Função Risco", a ser implementadas ações no sentido de viabilizar a gestão centralizada deste tipo de risco.

Em 2014, foi elaborado um manual de risco operacional que conforma as diretrizes das políticas e princípios gerais da gestão do risco operacional e foi aprovada uma matriz de registo de ocorrências, cuja operacionalização previa-se efetuar no primeiro trimestre de 2015 (BPC, 2014b).

Durante o desenrolar do ano de 2014, foi implementada igualmente a aplicação "Argus Compliance", cujo propósito é o controlo de transações suspeitas de branqueamento de capitais e de financiamento ao terrorismo. Esta é, sem dúvida, uma importante solução, uma vez que os incumprimentos à lei podem implicar sérios problemas e riscos de compliance.

\subsection{Composição da carteira de clientes do BPC}

O BPC atua em quatro áreas de negócio diferenciadas, nomeadamente, o Corporate, Pequenas e Médias Empresas, Particulares e Micro-Finanças. O segmento Corporate, que merece esclarecimento aqui, inclui as grandes empresas públicas e privadas e os organismos e instituições do Estado. O Gráfico 1 revela que do total da sua carteira de clientes Corporate, $90 \%$ são do setor privado, contra $10 \%$ do setor público, o que mostra claramente o compromisso do Banco para com o cumprimento da sua missão em contribuir para o desenvolvimento económico do país, promover a criação de emprego em parceria com o fomento da atividade empresarial e melhorar o bem-estar da população. 


\section{pontěditora}

Gráfico 1. Composição da Carteira de Crédito por Tipo de Cliente (\% do volume)

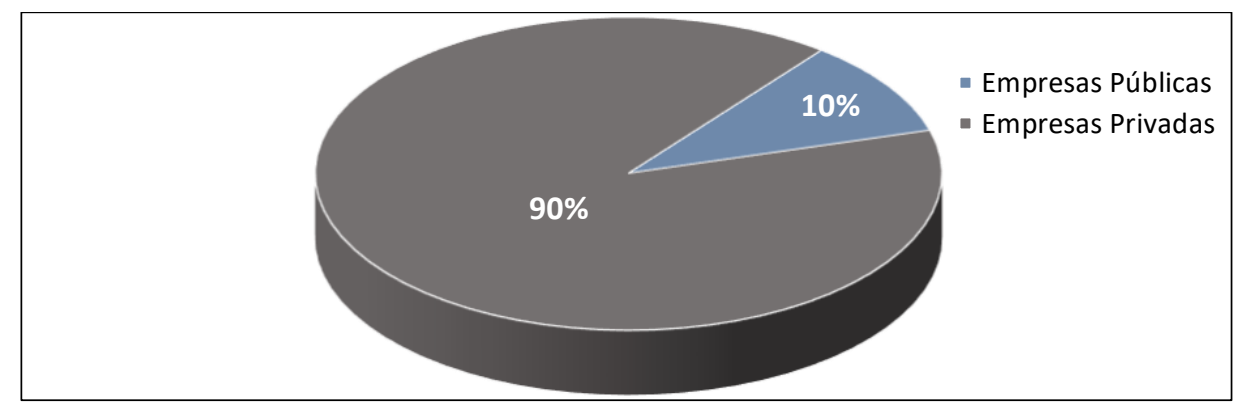

Fonte: Adaptado de BPC (2014b).

Segundo o relatório do BPC que está aqui a ser analisado, verificou-se uma ligeira contração no processo de dação de crédito às Pequenas e Médias Empresas, o que se deve à estratégia de recuperação de operações com elevada antiguidade, cujo peso deste segmento sobre o crédito vencido correspondeu a 46,7\%, contrariamente aos Particulares que, com a maior absorção dos empréstimos, se apresentam com um grau de incumprimento equivalente a 7,3\%, denotando menor risco.

\subsection{Créditos e depósitos do BPC}

O Gráfico 2 demonstra um crescimento do nível de créditos concedidos (cerca de $38,50 \%$ ) e dos depósitos captados (cerca de 64\%) entre 2012 e 2014 . No ano de 2014, o Banco de Poupança e Crédito concedeu, aos vários setores da economia, créditos que resultaram no saldo bruto final de 917,5 mil milhões de Kwanzas, equivalentes a 8,9 mil milhões de Dólares Americanos, o que correspondeu a um aumento de 243,8 mil milhões de Kwanzas (36,2\%) em comparação com o ano anterior. Refira-se que, 50,9\% do crédito foi destinado a particulares e 31,7 às grandes empresas. 
Gráfico 2. Depósitos vs. Créditos: 2012, 2013 e 2014

(valores em milhares de milhões de Kwanzas)

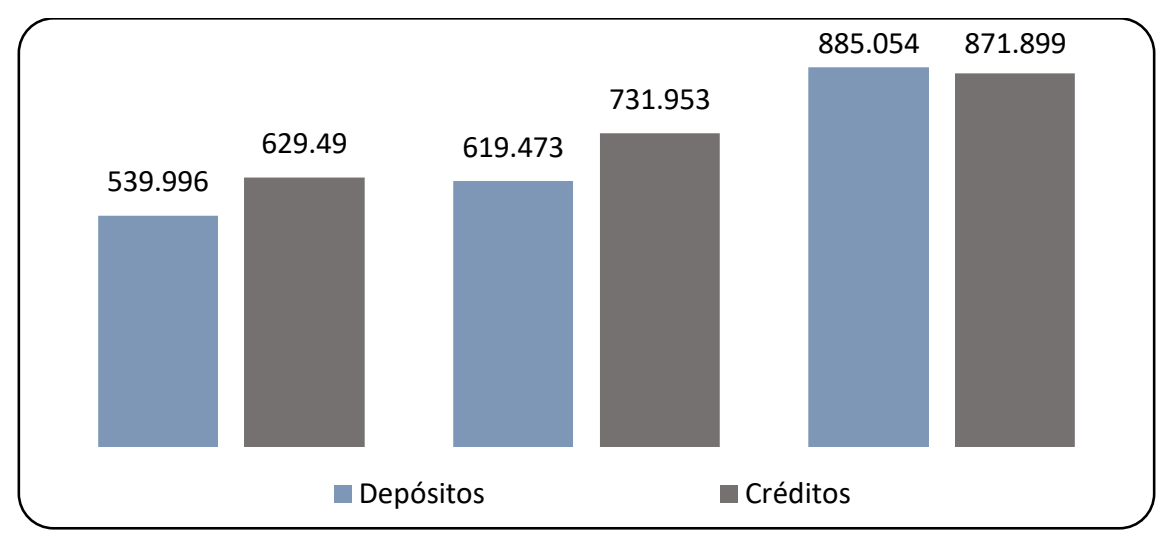

Fonte: Adaptado de BPC (2014b).

Observando o Gráfico 3, pode-se notar que o rácio de transformação dos depósitos em créditos do banco registou um aumento, passando de 96\% em dezembro de 2012 para 92,00\% em dezembro de 2013 e para 105,20\% em dezembro 2014, pesando sobre si a reestruturação de créditos vencidos e não pagos. O banco registou insuficiências de liquidez de forma continuada, o que dificultou de sobremaneira a gestão dos fundos, levando ao recurso aos mercados internacionais e ao mercado interbancário, para manter a sua força catalisadora no desenvolvimento da economia nacional.

Gráfico 3. Rácio de Transformação: 2012, 2013 e 2014

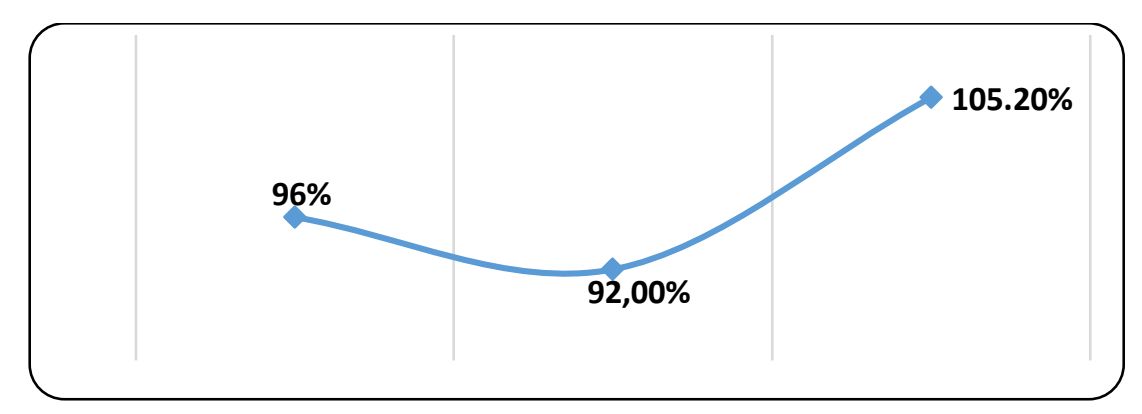

Fonte: Adaptado de BPC (2014b).

A situação acima descrita implicou uma situação de risco das operações de crédito, que se agudizou com os atrasos no cumprimento do serviço da dívida dos seus clientes. $\mathrm{O}$ nível dos riscos inerentes a esses atrasos é revisto mensalmente em função do tempo decorrido desde a data de entrada das operações em incumprimento, calculando-se as 


\section{pontěditora}

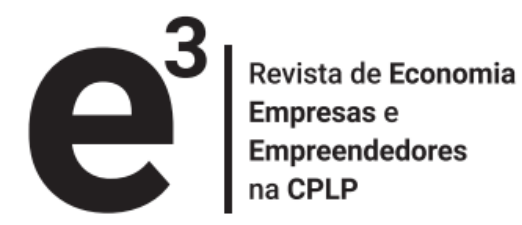

devidas provisões, conforme abaixo descrito.

\subsection{As provisões para créditos de liquidação duvidosa do BPC}

De acordo com o BPC, a 31 de dezembro de 2014, a dívida dos 20 maiores devedores totalizava 245,2 mil milhões de Kwanzas, ou seja, 26,8\% da carteira de crédito e 249,0\% dos Fundos Próprios Regulamentares, contra 29,4\% e 219,2\%, respetivamente, em 2013, demonstrando, por um lado, uma melhoria do grau de concentração, mas, por outro lado, uma degradação do nível de exposição

Os níveis de Créditos e Juros Vencidos ascenderam a 188,2 mil milhões de Kwanzas em 2014, contra 118,8 mil milhões de Kwanzas em 2013. Esse agravamento deveu-se fundamentalmente aos atrasos nos pagamentos de empresas com direitos de crédito sobre o Estado. Como corolário desse problema, o rácio do crédito vencido registou uma degradação, passando de $17,6 \%$ para $20,5 \%$.

Gráfico 4. Crédito Vencido vs. Provisões para Crédito: 2012, 2013 e 2014

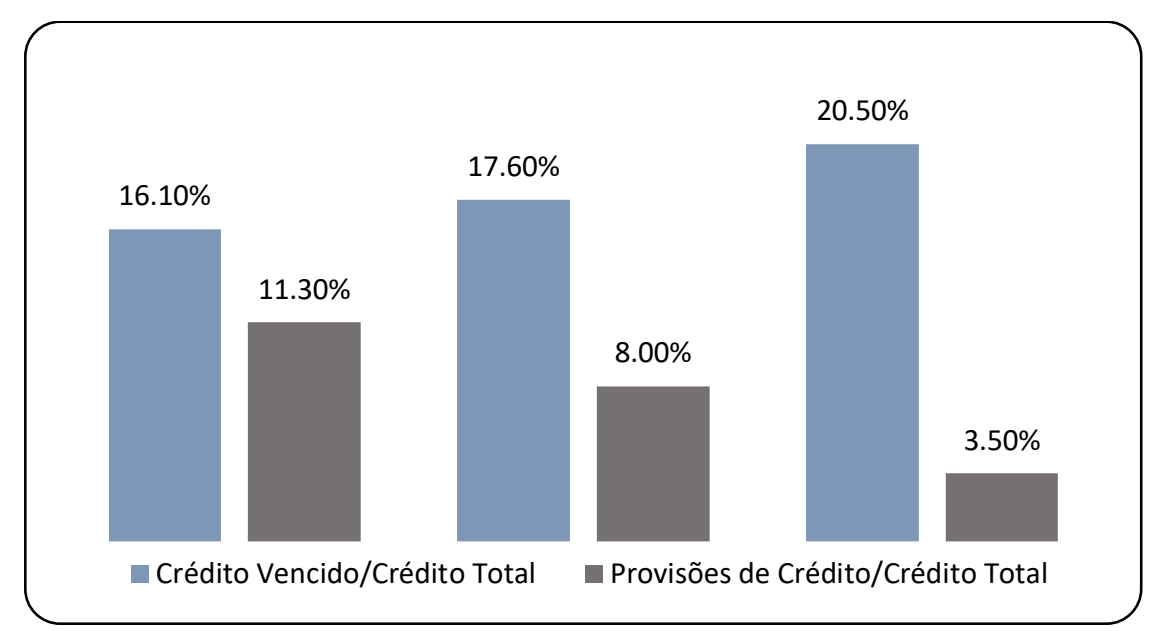

Fonte: Adaptado de BPC (2014b).

Nas operações de financiamento de projetos de investimento e de crédito, em geral, os bancos são forçados (a par das garantias e avales prestados) a constituir provisões, de acordo com o Aviso n. ${ }^{\circ}$ 3/2012, de 28 de março, que veio revogar o Aviso n. ${ }^{\circ}$ 4/2011, de 8 de junho, do BNA sobre a metodologia de classificação do crédito concedido a clientes e a determinação das respetivas provisões. Ora, o agravamento do crédito vencido, deveria inspirar uma maior reserva de contingência, isto é, um nível maior de 


\section{pontěditora}

provisões para cobranças duvidosas, o que não ocorreu, pois, como demonstra o gráfico acima, o banco foi diminuindo cada vez mais as provisões, de 11,10\% em 2012 para 8,00\% em 2013 e 3,50\% em 2014.

Finalmente, quando se analisa a estrutura do crédito vencido por tipo de cliente, constata-se um agravamento no grau de cobrabilidade das empresas, passando de 22,7\% para $32,2 \%$ o rácio de crédito vencido, a despeito de uma melhoria do rácio pertencente aos particulares para $3,5 \%$, contra os $8,9 \%$ do ano anterior.

\subsection{Crédito mal parado e avaliação de riscos de crédito no BPC}

Apesar dos riscos contra os quais o BPC procura acautelar-se, a verdade é que o Banco enfrenta graves problemas, traduzidos na qualidade dos créditos ou financiamento aos projetos que tem procurado abraçar. O nível de créditos mal parados tem crescido nos últimos anos e o Ministério das Finanças angolano já deu orientações para examinar essa questão na perspetiva de separar os ativos recuperáveis dos maus ativos que ainda figuram na carteira de crédito da instituição. No fundo quer-se verificar o que é e o que não é cobrável, com vista a desenvolver-se um processo do saneamento da carteira de créditos do BPC.

De acordo com informação pública veiculada, tanto pela imprensa nacional quanto pelos relatórios e contas da própria instituição, o BPC debate-se com um grave problema de provisões inadequadas face ao nível de créditos mal parados que degrada a sua carteira de créditos. Note-se que, o rácio de créditos mal parados do BPC, em especial a particulares, que constituem 95\% dos seus clientes, subiu de 17 para 23\% entre 2013 e o terceiro trimestre de 2014. Auditores externos que revisaram as contas do Banco de 2014 alegam que as provisões para riscos de crédito (crédito de cobrança duvidosa) não são suficientes para cobrir as perdas estimadas (Expansão, 2015).

As maiores perdas provêm de operações alvo de acordos de reestruturação de dívida de entidades fornecedoras do Estado. Ainda de acordo com essa entidade de auditoria independente, alegadamente por limitações dos seus sistemas informáticos, o Banco não consegue cumprir com os requisitos de provisão exigidos pelo Aviso n. ${ }^{\circ}$ 11/2014 do BNA. O crédito em mora atingiu, no final de 2014, cerca de 79,5 mil milhões de Kwanzas (772,7 milhões de Dólares), o que é, fundamentalmente, um reflexo dos atrasos nos pagamentos do Estado às empresas prestadoras de serviços. Este montante 


\section{pontěditora}

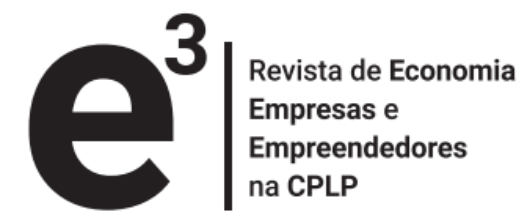

representava um crescimento de 289,7\%, em relação a dezembro de 2013, e correspondia a $27,3 \%$ do crédito total do segmento (15,9\% no fim de 2013$)$.

Assim, apesar da apresentação dos resultados dessa pesquisa revelarem que o BPC procura conduzir as suas operações tendo em conta as melhores práticas nacionais e até internacionais, acautelando-se contra os riscos inerentes à sua atividade, a verdade é que os problemas que apresenta revelam claramente problemas na sua gestão de riscos e/ou processos de análise e avaliação de projetos de investimentos.

$\mathrm{O}$ BPC continua a expandir a sua rede de balcões em todo o país e, à semelhança do que sucede com todo o sistema financeiro angolano, o Banco apresenta um processo de gestão do risco de crédito altamente centralizado, com as decisões de financiamento da maior parte dos investimentos a serem tomadas em Luanda, a capital do país.

Por ser essencialmente um banco de capitais públicos, o BPC tem sido condescendente em facilitar a concessão de créditos e/ou financiamento a projetos de investimento de uma forma mais elementar, descorando o rigor que se exige às instituições financeiras. Isto conduziu, até 2014, a que tenham sido concedidos créditos a entidades que nunca chegaram a honrar com o serviço da dívida, alegadamente porque os negócios falharam ou porque se registaram situações totalmente imprevistas.

De acordo com o Novo Jornal (2013), “o perfil dos clientes do BPC, maioritariamente funcionários públicos, e a sua composição acionista, são fatores apontados como responsáveis pelo aumento do crédito mal parado no banco público". A mesma fonte refere que o banco continua a ter dificuldades em recuperar o dinheiro emprestado, pois muitos dos beneficiários são funcionários públicos que, apesar de não terem os salários em atraso, depois de receberem o crédito mudam de banco, o que dificulta a recuperação do mesmo. Também é referida outra situação relacionada com o apoio ao empresariado nacional. Muitos empresários têm beneficiado dos créditos e não devolvem o dinheiro. Questionado se o banco não pede garantias a quem empresta, a mesma fonte esclareceu: "Para os funcionários públicos a garantia é o próprio salário destes, mas para os empresários e outros a garantia quase que não existia, porque o objetivo era potenciar os empresários angolanos. Mas, infelizmente muitos não souberam aplicar o dinheiro recebido e estão com dificuldades em restituir o capital recebido". Mesmo não avançando os montantes em causa, a fonte assumiu que a situação tem criado dificuldades de liquidez no banco e obrigou o Presidente da 


\section{pontěditora}

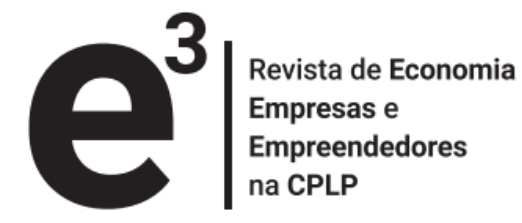

República a criar uma comissão multissetorial para avaliar o real estado financeiro do BPC, entretanto aconselhado a não fazer novas operações.

De acordo com uma outra fonte jornalística (Jornal de Angola, 2014), o presidente do conselho de administração do banco, Paixão Júnior, alega ser provável que uma pequena parte das dívidas ao BCP seja incobrável, porém, defende que a maioria dos créditos são recuperáveis porque as empresas, cujos projetos de investimento o banco financiou, existem e estão operacionais, e que as mais problemáticas, pelo menos possuem património e, quando o banco executar esse património vai poder reduzir parte do crédito mal parado.

É importante não descurar que o problema do crédito mal parado em Angola é transversal à toda banca, pelo que não deve ser visto como um problema exclusivo do BPC e, como corolário disso, também não deve ser encarado como um problema unicamente relacionado com o controlo interno do BPC, de modo particular, e do seu processo de análise e avaliação de projetos, de modo particular.Assim, observando o Gráfico 5, relativo ao rácio de crédito vencido, conforme avançado no Relatório e Contas do BNA de 2014, há um agravamento do mesmo entre 2012 e 2014.

Gráfico 5. Nível de créditos vencidos na banca angolana: 2012, 2013 e 2014

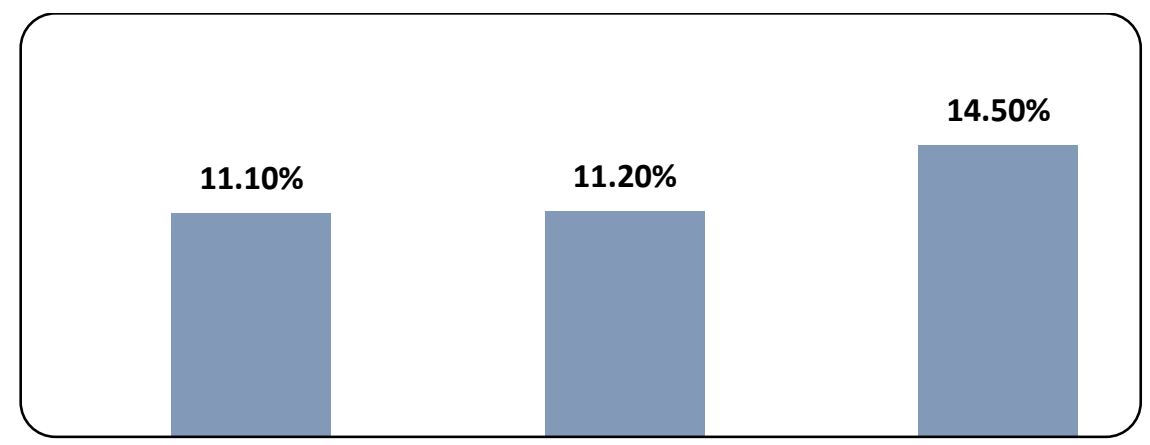

Fonte: Relatório e Contas (2014b).

Por fim, importa salientar que, o Banco visava apostar, entre outras, na melhoria dos mecanismos de gestão de riscos e de controlo interno, no desenvolvimento das competências dos recursos humanos e na promoção da educação e inclusão financeira.

\section{Conclusão}

Após a realização deste trabalho foi possível chegar a importantes conclusões, a respeito

$\mathrm{e}^{3}$ - Revista de Economia, Empresas e Empreendedores na CPLP | Volume 4 | Número 1 


\section{pontěditora}

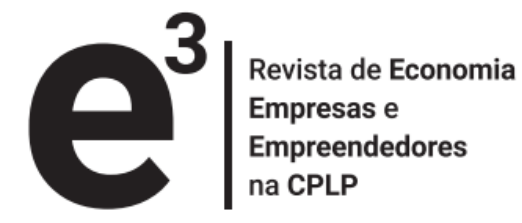

da dificuldade que o mesmo oferece, uma vez tratar-se de um assunto muito sensível. Para se ter uma ideia, foi muito difícil apurar o que realmente se passa no Banco para explicar os problemas de crédito mal parado. Para um observador independente, esses problemas podem ser decorrentes de eventuais deficiências do processo de análise e gestão de risco do Banco ou em função da própria conjuntura da situação da banca angolana.

Um problema importante verificado neste trabalho é que, pelo facto de tratar-se de um Banco público, o BPC muitas vezes vê-se forçado a apoiar projetos que de outra forma não seriam aceites. Muitos desses projetos não reúnem as condições necessárias para a sua aprovação, mas uma vez tratando-se de projetos ligados a iniciativas do Estado Angolano, o BPC é chamado a apoiar os mesmos.

Por outro lado, ficou claro aqui que a maioria do problema do crédito mal parado com que o Banco se debate provém de clientes alavancados por serviços prestados ao Estado. $\mathrm{Na}$ altura da aprovação desses projetos de investimento os mesmos pareciam reunir as condições para a sua aprovação, porém, com as dificuldades do Estado em pagar a essas entidades, as mesmas acabaram por se ver incapazes de honrar com o serviço da dívida. Este problema revela duas questões: a primeira é decorrente da própria conjuntura económica do país, pois, com a crise, muitos dos fornecedores de bens/serviços ao Estado vêem-se a braços com sérias dificuldades financeiras, até mesmo para se manterem operacionalmente, e ainda mais para honrar o serviço da dívida para com o BPC; a segunda questão, que se pode depreender dessa problemática, é que o Banco terá descurado os riscos que corria ao financiar parte desses projetos, o que indiciaa problemas no seu processo de análise e avaliação de projetos de investimento.

Para o agravamento do crédito mal parado terá contribuído a própria situação económica de Angola. Porém, os processos de análise e avaliação de projetos do BPC apresentam fragilidades em determinados aspetos. Por exemplo, o Banco muitas vezes não exige as devidas garantias reais ou a aplicação de seguros de crédito, exigências que normalmente dariam ao banco a possibilidade de recuperar parte significativa dos créditos vencidos ou mal parados.

Portanto, o problema dos créditos mal parados do BPC estará ligado à conjuntura de crise económica e financeira do país, mas também a problemas ligados com o processo de análise e avaliação de projetos de investimentos que vinham sendo submetidos aos

$\mathrm{e}^{3}$ - Revista de Economia, Empresas e Empreendedores na CPLP | Volume 4 | Número 1 


\section{pontěditora}

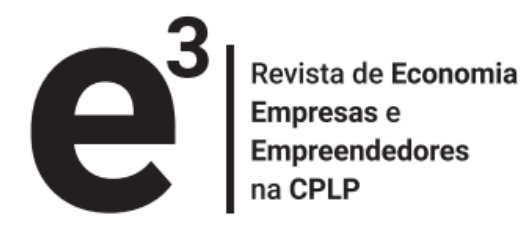

seus diferentes balcões de atendimento nas diversas regiões do país.

No fundo, o problema do banco identifica-se com os decorrentes da informação assimétrica, nomeadamente: a seleção adversa e o risco moral. O Banco precisa de melhorar a forma como seleciona os projetos de investimento que financia. É preciso tornar mais transparente e rigoroso o processo, não só de análise e avaliação de projetos, mas, sobretudo, o de seleção ou aprovação.

Por outro lado, o BPC tem de preparar as condições necessárias para resolver o problema de risco moral dos seus clientes. Para tal, o Banco tem de exigir garantias reais para poder recuperar parte significativa do crédito vencido ou mal parado. Posto isso, importa realçar que o processo de análise e avaliação de projetos de investimento do BPC não ficam aquém das boas práticas nacionais e internacionais, estando o problema ligado à especificidade ou caráter do próprio banco.

Enquanto o banco subjazer refém da situação acima descrita, os problemas vão continuar, por mais perfeito que seja o seu processo de análise e avaliação de projetos. Logo, os problemas do Banco estão mais ligados a condicionalismos impostos pelo Estado e também pelo pouco cuidado na seleção dos projetos aprovados. Em função disso, o Banco praticamente congelou o fluxo de créditos que vinha concedendo até 2014, com a vista a reestruturar a sua atuação em termos de tentativas de recuperação de créditos mal parados, com processos judiciais em curso, conforme avançados por fontes junto da instituição.

Por fim, importa salientar que, relativamente às perguntas científicas identificadas neste trabalho, pode-se concluir que o processo de análise e avaliação de projetos de investimento no BPC é desenvolvido no âmbito de procedimentos regulares, semelhantes ao que sucede com outros bancos nacionais e internacionais.

Não obstante o próprio sistema financeiro angolano ver-se neste momento a braços com sérias dificuldades de mitigação de riscos, e o Banco procurar acautelar-se contra os riscos inerentes ao processo de seleção e atribuição de crédito, pode-se concluir que os elevados níveis de crédito mal parado são um sinal de problemas ao nível do controlo interno do Banco. Porém, este problema afigura-se como um assunto bastante delicado, que só pode ser resolvido mediante uma auditoria ou avaliação do sistema de controlo interno do Banco.

Assim, pode-se depreender aqui que os objetivos deste trabalho foram atingidos até

$\mathrm{e}^{3}$ - Revista de Economia, Empresas e Empreendedores na CPLP | Volume 4 | Número 1 


\section{pontěditora}

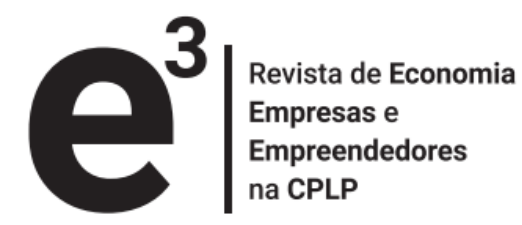

certa medida, dadas as dificuldades de obtenção de dados delicados, relacionados com os procedimentos pouco claros de concessão de créditos no banco em análise. $\mathrm{Na}$ medida em que, o núcleo dos problemas de crédito mal parado do BPC reside no controlo interno, numa lógica de desenvolvimento de trabalhos futuros, seria interessante a realização de uma investigação relacionada com a avaliação daquele sistema do Banco, com a vista à procura e correção das suas falhas.

\section{Referências bibliográficas}

- Albino, F., Tavares, F. \& Pacheco, L. (2016). "Investimento Direto Estrangeiro em Angola". Portuguese Journal of Finance, Management and Accounting. 2(3), pp. 3-34.

- Barros, C. P. (2007). Avaliação Financeira de Projetos de Investimento. Lisboa: Escolar Editora, Portugal.

- BPC (2011). Relatório e Contas. Banco de Poupança e Crédito. Luanda, Angola.

- BPC (2014a). Regulamento Geral de Crédito. Banco de Poupança e Crédito. Luanda, Angola.

- BPC (2014b). Relatório e Contas. Banco de Poupança e Crédito. Luanda, Angola.

- Expansão (2015). "BPC com provisões insuficientes para crédito malparado", Jornal Expansão. Disponível em: http://expansao.co.ao/artigo/57760/bpc-comprovisoes-insuficientes-para-credito-malparado (maio de 2015).

- Jornal de Angola (2014). "BPC faz o exame a dívidas à banca". Jornal de Angola disponível

em: http://jornaldeangola.sapo.ao/economia/banca/bpc_faz_o_exame_a_dividas_a_b anca (22 de abril de 2014).

- KPMG (2013). Análise ao setor Bancário Angolano. Luanda, Disponível: <http://www.kpmg.com/PT/pt/IssuesAndInsights/Documents/bank-ao201 3.pdf> (3 de novembro de 2014).

- Marques, A. (1998). Concepção e análise de projectos de investimento. Lisboa: Edições Sílabo, Portugal.

- Novo Jornal (2013). “Cresce o crédito mal parado - situação inquieta bancos”. 


\section{pontěditora}

Retirado de: https://centralangola7311.files.wordpress.com/2013/11/novo-jornal302-conomia.pdf. (1 de novembro de 2013).

- Patah, L., \& Carvalho, M. (2016). "Sucesso a partir de investimento em metodologias de gestão de projetos". Production, 26(1), pp. 1-16.

- Soares, I., Moreira, J., Pinho, C., \& Couto, J. (2007). Decisões de InvestimentoAnálise Financeira de Projectos. Lisboa: Edições Sílabo.

- Souza, J. S., \& Neto, F. J. (2012). "O impacto da incorporação da inflação na análise de projetos de investimentos". Produção, 22(4), pp. 709-717

- Tavares, F. O., Pacheco, L., \& Pires, M. R. (2016). "Gestão do Risco nas "PME de Excelência" Portuguesas". Revista Tourism \& Management Studies, 12(2), pp. 135-144.

- Tavares, F. O., Pacheco, L., \& Almeida, E. F. (2015). "Financiamento das pequenas e médias empresas: análise às empresas do distrito do Porto em Portugal”. RAUSP - Revista de Administração, 50(2), pp. 254-267.

\section{(cc) EY-NC-SA}

O trabalho $\mathrm{e}^{3}$ - Revista de Economia, Empresas e Empreendedores na CPLP está licenciado com uma Licença Creative Commons - Atribuição-NãoComercial-Compartilha Igual 4.0 Internacional. 


\title{
Planeamento estratégico aplicado à carreira musical
}

\author{
Strategic plan applied to the musical career
}

Lucas Caldoncelli Gomes ${ }^{1}$; Leila Vaz da Silva ${ }^{2}$; Daniela Ferreira ${ }^{3}$.

${ }^{1}$ E-mail: lucascaldoncelli@gmail.com

Centro Universitário Metodista Izabela Hendrix

${ }^{2}$ E-mail: leila.silva@izabelahendrix.metodista.br Centro Universitário Metodista Izabela Hendrix

\footnotetext{
${ }^{3}$ E-mail: daniela.ferreira@izabelahendrix.metodista.br Centro Universitário Metodista Izabela Hendrix
}

Resumo: O presente artigo apresenta as principais etapas para o desenvolvimento de um planeamento estratégico para um empreendimento musical. Além das habilidades artísticas necessárias, a gestão estratégica apresenta-se como uma ferramenta fundamental para que se consiga alavancar uma carreira artística. Através desse documento foram definidas abordagens e conceitos necessários para se traçar os princípios norteadores (valores, missão e visão) e determinar os objetivos organizacionais. Além disso, realizou-se um trabalho exploratório dos ambientes que compõem o mercado musical na cidade de Belo Horizonte. A metodologia adotada para o estudo foi quanto aos fins exploratória, descritiva e aplicada. Quanto aos meios, tratou-se de um estudo de caso com abordagem quantitativa e qualitativa. $\mathrm{O}$ instrumento de coleta de dados deu-se por meio de entrevista com empreendedores do segmento musical e questionário estruturado aplicado via internet, para a pesquisa concorrencial. Após a etapa de coleta de dados, foi elaborado um plano estratégico, especificando os objetivos estratégicos globais desejados pelo artista, a fim de se elaborar um plano de ação a ser aplicado no desenvolvimento do empreendimento musical em questão.

Palavras-chave: Planeamento Estratégico; Empreendedorismo; Mercado da Música.

\begin{abstract}
This article presents the main steps of strategic planning for the development of musical enterprise. In addition to the necessary artistic skills, strategic management presents itself as a fundamental tool for the achievement of an artistic career. Through this document, the necessary approaches and concepts were defined to guide the guiding principles (values, mission and vision) and to determine the organizational objectives. Moreover, an exploratory work was carried out on the environments that make up the music market in the city of Belo Horizonte. The methodology used for the study was for exploratory, descriptive and applied purposes. As for the means, it was a case study with a quantitative and qualitative approach. The instrument of data collection was done through an interview with entrepreneurs of the musical segment and structured questionnaire applied through the internet, for competitive research. After the data collection stage, a strategic plan was drawn up, specifying the overall strategic objectives desired by the artist, in order to elaborate a plan of action to be applied in the development of the musical enterprise in question.
\end{abstract}

Key-Words: Strategic planning; Entrepreneurship; Music Market. 


\section{Introdução}

A indústria musical, através dos seus três eixos principais: apresentações, fonogramas e direito autoral, faz parte da chamada economia criativa e abrange outros setores artísticos e culturais, bem como o setor de tecnologia da informação e da comunicação, e ainda os serviços de design, publicidade, moda e arquitetura (SALAZAR, 2015).

Neste contexto torna-se fundamental ao empreendedor musical diferenciar-se, devendo possuir uma série de conhecimentos teóricos, habilidades técnicas e atitudes, não só relacionadas às artes, mas também um profundo conhecimento na gestão empresarial, em marketing e na cultura empreendedora para impulsionar a sua carreira.

Novos consumidores musicais exigem a adoção de novos modelos de negócios, sobrevive somente aquele que se adapta melhor e mais rápido às mudanças do ambiente. Segundo Levesque (1999), as estratégias adotadas no passado possibilitaram a sobrevivência até ao momento, mas uma nova estratégia deve ser criada no sentido de se garantir a sobrevivência diante das mudanças no ambiente.

Diante dessas considerações, pergunta-se: é possível impulsionar carreiras musicais independentes por meio da cultura empreendedora e do planeamento estratégico? Quais estratégias podem impulsionar uma carreira musical independente na capital mineira?

O objetivo geral consiste em desenvolver um planeamento estratégico para um empreendimento musical (Lugera) a fim de se impulsionar uma carreira musical independente.

Os objetivos específicos são:

- Definir os princípios norteadores (valores, missão e visão) da banda Lugera;

- Analisar a concorrência por meio de entrevistas e questionários com o maior número possível de agentes musicais na cidade de Belo Horizonte;

- Desenvolver um planeamento estratégico para um empreendimento musical (Lugera), formulando os objetivos estratégicos; 


\section{pontěditora}

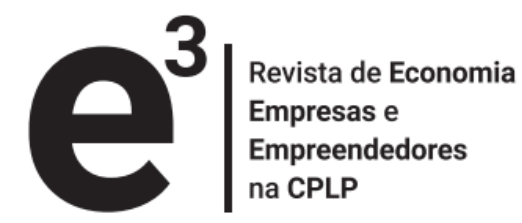

- Elaborar um plano de ação a ser aplicado no desenvolvimento do empreendimento musical.

Belo Horizonte possuí uma enorme população de artistas ligados à área musical. Infelizmente a grande maioria não atinge os seus objetivos, justamente, por não possuir um planeamento estratégico que vislumbre objetivos a longo prazo. Por meio da experiência do autor no ramo musical, pretende-se desenvolver o planeamento estratégico da sua banda, Lugera, de modo que essa ferramenta possibilite traçar e alcançar metas no médio e longo prazo, de forma a impulsionar a carreira musical.

A estratégia no ramo musical constitui uma das principais peças numa carreira de sucesso e, pela falta dele, muitos músicos, mesmo talentosos, não chegam aonde poderiam chegar e ficam estagnados em suas carreiras.

Portanto, um trabalho científico com o objetivo de pesquisar estratégias de gestão para propostas musicais apresentará ferramentas de grande valia no desenvolvimento de uma cena musical mais forte e consciente de suas capacidades, considerando que os gestores de trabalhos musicais muitas vezes são os próprios integrantes do grupo. Uma base de conhecimento bem estruturada apresenta um caminho para que se consiga alavancar os negócios.

O presente artigo científico também se justifica como critério imperioso para que o autor obtenha o título de Bacharel em administração do Curso de Administração do Centro Universitário Metodista Izabela Hendrix, e nesse sentido, o que se deseja é unir o útil ao agradável.

\section{Empreendedorismo}

Um primeiro exemplo de definição de empreendedorismo pode ser exemplificado com a tentativa de Marco Polo em estabelecer uma rota comercial para o Oriente. $\mathrm{Na}$ época, ele assinou um contrato para vender mercadorias de um capitalista. No caso, todos os riscos físicos e emocionais foram assumidos por Marco Polo. Durante a Idade Média, o empreendedor era aquele que gerenciava grandes projetos de produção, mas sem assumir riscos excessivos, uma vez que os recursos eram disponibilizados, geralmente, por governos. Somente no século XVII, surgem indícios de relação entre assumir riscos e empreendedorismo.

$\mathrm{e}^{3}$ - Revista de Economia, Empresas e Empreendedores na CPLP | Volume 4 | Número 1 


\section{pontěditora}

Neste período, os empreendedores faziam contratos com governos para a realização de serviços ou fornecimento de produtos. Richard Cantillon, importante escritor e economista do século XVII, foi um dos primeiros a diferenciar o empreendedor (aquele que assume riscos) do capitalista (aquele que fornecia capital) e, finalmente, no século no XVIII o capitalista e o empreendedor foram totalmente diferenciados, possivelmente devido à Revolução Industrial (DORNELAS, 2012).

Nos séculos XIX, XX e até os dias atuais, empreendedores são frequentemente confundidos com os gerentes ou administradores; a respeito desse assunto,

Todo empreendedor necessariamente deve ser um bom administrador para obter sucesso, no entanto, nem todo bom administrador é um empreendedor. $O$ empreendedor tem algo mais, algumas características e atitudes que o diferenciam do administrador tradicional (DORNELAS, 2012, p. 21)

Segundo o SEBRAE (2017), o futuro de uma empresa depende dos cuidados do seu dono. O perfil e o talento do futuro empresário são fundamentais para o sucesso do negócio. Um espírito criativo e pesquisador é uma das qualidades fundamentais de um empreendedor. A essência do empresário de sucesso é a busca de novos negócios e oportunidades, além da preocupação com as necessidades dos clientes e a melhoria dos produtos e serviços (DORNELAS, 2012).

Acredita-se, hoje, que o empreendedor seja o "motor da economia", um agente de mudanças. O empreendedor é alguém que sonha e busca transformar o seu sonho em realidade (DOLABELA, 1999).

O empreendedorismo, para Dornelas (2012), é a identificação de novas oportunidades e negócios, independentemente dos recursos que se apresentam disponíveis ao empreendedor, ou seja, identificar ideias inovadoras, procurando transformá-las em oportunidade, mesmo com poucos recursos. Um empreendedor de sucesso é aquele que busca o novo, planeia e organiza as suas ideias, procurando criar ou atender às necessidades das pessoas. Procura organizar os recursos disponíveis para atingir objetivos específicos.

Segundo Dornelas (2012), quando se compara o papel e função do empreendedor com o do administrador existem muitos pontos em comum entre ambos. O empreendedor é um administrador, mas diferentemente dos gerentes e executivos tradicionais, os empreendedores são mais visionários. Assim, à medida que a 


\section{pontěditora}

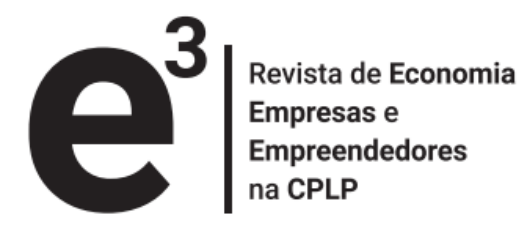

organização cresce, os empreendedores têm dificuldades com as decisões do negócio, pois concentram-se mais em aspetos estratégicos. Algumas orientações são básicas, a definição da estratégia, a análise de oportunidades, o comprometimento e o controlo dos recursos e a estrutura gerencial. Percebe-se diferenças no domínio de empreendedores e administradores.

Os empreendedores são orientados pela perceção de oportunidades e ação, utilizam o mínimo de recursos existentes, buscando eficiência, estão envolvidos numa estrutura gerencial informal com o relacionamento pessoal. Outros aspetos relevantes no comportamento empreendedor são a busca por independência, criando algo novo para ganhar dinheiro, envolvimento direto nos negócios, capacidade de assumir riscos calculados e aprendizado com erros e falhas. Assim Dornelas conclui:

O empreendedor de sucesso possui características extras, além dos atributos do administrador, e alguns atributos pessoais que, somados a características sociológicas e ambientais, permitem o nascimento de uma nova empresa. De uma ideia, surge uma inovação, e desta, uma empresa (DORNELAS, 2012, p. 23).

A respeito da relação do empreendedorismo com outras disciplinas, Baron e Shane explicam:

Fica claro que o campo do empreendedorismo não existe em um vácuo intelectual; pelo contrário, suas raízes estão firmemente assentadas em várias disciplinas mais antigas que, juntas, lhe dão sustentação para compreender um dos mais complexos - e importantes - processos de negócio que existe (BARON; SHANE, 2007, p. 11).

Conclui-se que a ciência da Administração torna-se de grande importância aos empreendedores, pois ajuda-os a adquirir competências e habilidades complementares ao seu conhecimento, preparando-os para as mais diferentes tarefas envolvidas no processo de criação e gerência de novos negócios.

\subsection{Planeamento Estratégico: abordagens e conceitos}

Em tempos de mudanças e transformações que ocorrem de forma rápida e inesperada, a estratégia passa a ser uma direção salvadora nas organizações, capaz de levá-las aos seus objetivos mesmo com toda a instabilidade. Quanto maior a mudança

$\mathrm{e}^{3}$ - Revista de Economia, Empresas e Empreendedores na CPLP | Volume 4 | Número 1 


\section{pontěditora}

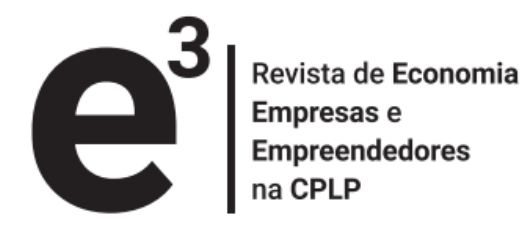

maior a necessidade de estratégia organizacional. $\mathrm{O}$ detalhe consiste na necessidade, na atualidade das estratégias apresentarem-se ágeis, rápidas, flexíveis e inovadoras, permitindo melhor o enfrentamento das turbulências presentes no ambiente competitivo (CHIAVENATO; MATOS, 2009).

O estudo da administração estratégica foi primeiramente adotado nas escolas de administração americanas, nos anos 50, após a Fundação Ford e a Carnegie Corporation patrocinarem uma pesquisa sobre currículos. Um resumo desta pesquisa recomendou que o ensino de administração passasse a incluir um curso de capacitação em política de negócios. O enfoque de tal curso seria a identificação, análise e a solução de problemas do mundo real em várias áreas. Isso permitiria aos estudantes realizar julgamentos. Com o tempo, tal enfoque ampliou-se para incluir a organização global e o seu ambiente, tornando a responsabilidade social e a ética, assim como o impacto de factores políticos, legislativos e económicos, assuntos primordiais no êxito das operações de uma organização (CERTO; PETER, 2005).

Mintzberg (2006) divide a estratégia em cinco definições:

1 - Estratégia como plano: a estratégia significa um plano unificado amplo e integrado, criado para assegurar que os objetivos básicos da empresa sejam atingidos. Planos necessariamente criados antes das ações, as quais vão aplicar-se, e desenvolvidos consciente e propositalmente;

2 - Estratégia como padrão: definir uma estratégia como plano não seria suficiente, necessário se faz uma definição que englobe o comportamento resultante. Portanto, estratégia representa a consistência no comportamento, pretendida ou não;

3 - Estratégia sobre o que: rotular estratégias como planos ou padrões levantam a questão básica: estratégias sobre o quê? Estratégias referem-se a coisas importantes, táticas são os detalhes. Mas alguns detalhes podem ser estratégicos. Portanto, o que é estratégico depende do ambiente. Não se deve usar rótulos para indicar que questões são inevitavelmente mais importantes que outras. A estratégia refere-se, potencialmente, a tudo;

4 - Estratégia como posição: um meio de localizar uma organização num ambiente. A estratégia torna-se uma força, ou a combinação entre organização e ambiente, ou seja, entre o ambiente interno e externo. Num contexto de vários 


\section{pontěditora}

competidores a estratégia torna-se um nicho, ou seja, um local no ambiente onde os recursos concentram-se;

5 - Estratégia como perspetiva: nesse aspeto a estratégia constitui para a organização aquilo que a personalidade significa para o indivíduo. Não significando apenas uma posição escolhida, mas também uma maneira fixa de olhar o mundo. Neste contexto, estratégia envolve uma perspetiva compartilhada pelos membros de uma organização, por suas intenções e/ ou por suas ações.

Assim, a estratégia não é apenas a noção de como lidar com um grupo de concorrentes, ela também nos leva a algumas questões mais fundamentais sobre as organizações como instrumentos para percepção e ação coletiva. (MINTZBERG, 2006, p. 29)

Segundo Certo e Peter (2005, p. 3), "a administração estratégica é definida como um processo contínuo e interativo que visa manter uma organização como um conjunto apropriadamente integrado a seu ambiente". Percebe-se nesse conceito a natureza de longo prazo do planeamento estratégico devido a seu caráter contínuo. Assim, a necessidade de adaptar as estratégias de acordo com as condições do ambiente apresentado.

Chiavenato e Matos (2009, p. 1) acrescentam que "a visão estratégica é antecipatória e proativa. Antever e não agir estrategicamente é realizar a profecia do caos, como um feiticeiro que acaba mergulhando no caldeirão fervente para provar suas teorias". Portanto, as organizações que se planeiam estão operando estrategicamente contra os movimentos que venham a ameaçar seu funcionamento, devido a mudanças no ambiente, e as que não planeiam, ou que planeiam, mas não agem, estão contribuindo para a própria destruição.

Certo e Peter (2005) resumem o planeamento estratégico como:

Um processo contínuo e interativo voltado para a manutenção da organização como um todo integrado de forma apropriada a seu ambiente. Esse processo envolve análise do ambiente, estabelecendo diretrizes organizacionais, formulações da estratégia, implementação da estratégia e controle estratégico. Também é importante que as principais funções de negócio dentro de uma organização - marketing, operações e finanças - estejam integradas com o processo de administração estratégica. (CERTO; PETER, 2005, p. 17)

$\mathrm{e}^{3}$ - Revista de Economia, Empresas e Empreendedores na CPLP | Volume 4 | Número 1 


\section{pontěditora}

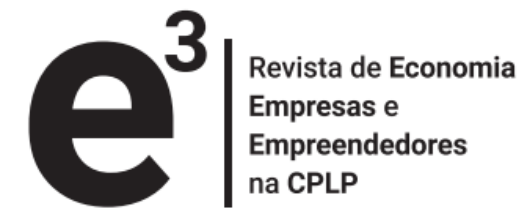

Ainda de acordo com Certo e Peter (2005, p. 13), "o administrador estratégico bem-sucedido deve ser capaz de analisar as principais funções de negócio dentro da organização e entender como elas afetam o processo de administração estratégica e de que maneira devem ser integradas a ele". Assim sendo, destaca-se a importância de uma análise profunda das funções do negócio dentro de uma organização. Como ponto de partida de um planeamento estratégico, torna-se necessário um planeamento financeiro da empresa, criando-se um sistema ajustado com a quantidade de recursos disponíveis. Depois, deve-se planear o futuro, deixando de trabalhar somente com aquilo que se tem em mãos e projetar quais são as ambições futuras da organização, e como o marketing, as operações e o bom gerenciamento dos recursos materiais e financeiros podem auxiliar na realização de tais planos (ROCHA, 2012).

Complementando, Chiavenato e Matos (2009) conceituam o planeamento estratégico como:

Um processo organizacional compreensivo de adaptação organizacional pela aprovação, tomada de decisão e avaliação. Procura responder a algumas questões básicas, como: por que a organização existe, o que e como ela faz. $O$ resultado do processo é um conjunto de planos altamente integrado e flexível que serve para guiar a ação organizacional por um prazo de tempo pela frente (CHIAVENATO; MATOS, 2009, p. 36)

Segundo os autores, o planeamento estratégico apresenta cinco características fundamentais:

1 - Relaciona-se com a adaptação da organização a um ambiente mutável. Foca nas relações entre a organização e o seu ambiente de tarefa, muito sujeito a incerteza a respeito dos eventos ambientais que se sucedem numa ampla variedade de cursos de ação;

2 - Orientado para o futuro, para tanto depende da construção de cenários e de desdobramentos esperados da situação atual;

3 - Envolve toda a organização, utilizando todos os seus recursos e competências, no sentido de obter sinergia de suas capacidades e potencialidades. A resposta estratégica da organização envolve um comportamento global, compreensivo, holístico e sistémico. O planeamento estratégico deve ficar na cabeça e no coração das pessoas. Elas precisam conhecer os objetivos a alcançar de maneira consciente, compromissada e engajada;

$\mathrm{e}^{3}$ - Revista de Economia, Empresas e Empreendedores na CPLP | Volume 4 | Número 1 


\section{pontěditora}

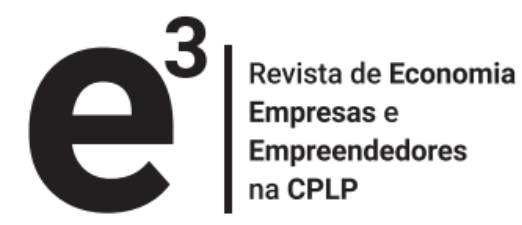

4 - Processo de construção de consenso, dada a diversidade dos interesses e necessidades dos parceiros que contribuem para que a organização possa alcançar os seus objetivos. Aceitação ampla e incondicional para que o planeamento estratégico possa ser realizado pelas pessoas em todos os níveis organizacionais;

5 - Forma de aprendizagem organizacional já que constitui uma tentativa permanente em aprender a ajustar-se a um ambiente complexo, dinâmico, competitivo e mutável. Os ajustes internos apresentam sempre novos estilos de aprender a conviver em conjunto e cooperar para que a união faça a força da organização.

\subsection{Processo de administração estratégica}

Certo e Peter (2005) dividem o processo da administração estratégica em 5 etapas distintas a seguir:

Etapa 1 - Análise do ambiente: consiste num processo de monitoração do ambiente organizacional, também conhecido como análise SWOT. Entende-se ambiente organizacional como sendo todos os factores, internos e externos, que podem influenciar o progresso alcançado por meio da realização dos objetivos.

Analisar o ambiente de negócio consiste em identificar os principais factores que influenciam direta ou indiretamente um empreendimento. Factores económicos, socioculturais, demográficos, político-legais, tecnológicos e naturais precisam ser mapeados, pois podem provocar impacto ao negócio. Além disso, o empreendedor precisa conhecer mais detalhadamente o setor que pretende atuar.

De acordo com Kotler e Keller (2006), as empresas bem-sucedidas reconhecem as necessidades e as tendências não atendidas e tomam medidas para lucrar com elas. Segundo os autores, para ajudar as organizações a identificar mudanças culturais, que possam trazer novas oportunidades ou ameaças, várias empresas oferecem previsões socioculturais.

Ainda segundo Kotler e Keller (2006), a principal força a ser monitorada é a população. Afinal, os mercados são compostos por pessoas. Aspetos como o tamanho e a taxa de crescimento da população de diferentes regiões, composição etária e étnica da população, graus de instrução, padrões familiares, são de fundamental importância para a compreensão das tendências demográficas e como tais factores podem influenciar os negócios.

$\mathrm{e}^{3}$ - Revista de Economia, Empresas e Empreendedores na CPLP | Volume 4 | Número 1 


\section{pontěditora}

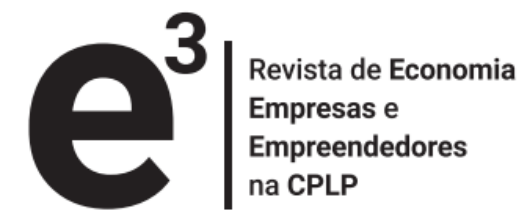

As mudanças no ambiente político-legal possuem uma força muito grande e afetam as decisões. Esse ambiente é constituído por leis e órgãos governamentais que influenciam, regem e limitam várias organizações e pessoas. Algumas vezes, essas leis geram novas oportunidades de negócios, por exemplo Leis de Incentivo à Cultura. As duas principais tendências no ambiente político-legal são: o aumento da legislação que regulamenta os negócios e o crescimento dos grupos de interesses especiais (KOTLER e KELLER, 2006).

Na visão de Chiavenato (2003), as condições legais formam a legislação que está em vigor que afeta direta ou indiretamente as empresas, auxiliando-as ou impondo restrições às suas atividades organizacionais, como exemplo as leis comerciais, trabalhistas, fiscais e civis. As condições políticas correspondem às decisões que influenciam as organizações e orientam as condições económicas. $\mathrm{O}$ ambiente políticolegal é primordial, visto que afeta diretamente a sociedade e as organizações, devido às mudanças políticas e ao surgimento de leis que são aprovadas ou modificadas que podem afetar diretamente as ações das organizações (KOTLER e KELLER, 2006). Em vista disso, as organizações devem analisar de forma criteriosa as considerações político legais ao definir suas estratégias de negócios.

De acordo com Kotler e Armstrong (1998), para ser bem sucedida, uma empresa deve satisfazer necessidades e desejos dos consumidores melhor do que os seus concorrentes. O desenvolvimento que ocorre nas outras organizações provoca profundas influências nas organizações, principalmente quando se trata de tecnologia sujeita a inovações, ou seja, tecnologia dinâmica de futuro imprevisível. As organizações precisam adaptar-se e incorporar tecnologia que provém do ambiente geral para não perderem a sua competitividade.

Etapa 2 - Estabelecimento das diretrizes organizacionais: determinação dos princípios norteadores da organização. Os indicadores principais da direção para a qual leva-se a organização são os valores, a missão e a visão. Valores "são os balizamentos para o processo decisório e o comportamento da empresa no cumprimento da sua missão" (VASCONCELOS; PAGNONCELLI, 2001, p. 31); Missão “é a razão de existir da empresa no seu negócio" (VASCONCELOS; PAGNONCELLI, 2001, p. 31); e Visão "é a explicitação do que se visualiza para a empresa” (VASCONCELOS; PAGNONCELLI, 2001, p. 31). 


\section{pontěditora}

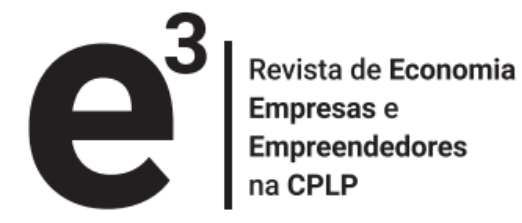

Etapa 3 - Formulação da estratégia: define-se a estratégia como um curso de ação para garantir que se alcance os objetivos.

Etapa 4 - Implementação da estratégia: deve pôr em ação estratégias que surgiram de etapas anteriores dentro do processo de administração estratégica. Sem implementação efetiva da estratégia as organizações são incapazes de obter os benefícios da realização de uma análise organizacional, do estabelecimento de uma diretriz organizacional e da formulação da estratégia organizacional.

Etapa 5 - Controlo estratégico: representa um tipo característico de controlo organizacional que se aplica no monitoramento e na avaliação do processo de administração estratégica para melhorá-lo e assegurar-lhe um funcionamento apropriado.

Portanto, trata-se de um conjunto de compromissos, decisões e ações imperiosas às empresas realmente interessadas em obter vantagens competitivas e retornos acima da média.

Ao analisar adequadamente o ambiente interno e externo determina-se os recursos, capacitações, e competências essenciais, os chamados inputs ou fontes de informações estratégicas. Com as informações, o negócio desenvolve a sua visão e missão e formula a sua estratégia. Para implementar uma estratégia tomam-se ações, a fim de obter vantagem competitiva e retornos acima da média. Ações estratégicas eficazes são as que ocorrem de maneira integrada entre as etapas de formulação e implementação da estratégia e, portanto, produzem os resultados desejados. O processo torna-se dinâmico, visto que os mercados mudam constantemente e a gestão de tais estruturas, por meio das informações estratégicas pertinentes, está em constante evolução (HITT; IRELAND; HOSKISSON, 2008).

Complementando, de acordo com Hamel e Prahalad (1995), considera-se o planeamento estratégico também como um meio de competição pela previsão do futuro do setor, proporcionando aos gestores respostas a três questões fundamentais: Que novos tipos de benefícios poderemos oferecer aos clientes? Que novas competências precisaremos desenvolver ou adquirir para oferecer esses benefícios aos clientes? Como será o contacto? 
Segundo Hamel e Prahalad (1995, p. 83), "a meta de competição pela previsão do futuro do setor é criar a melhor base de premissas possível sobre o futuro e, assim, desenvolver a presciência necessária para moldar a evolução do setor".

\subsection{Importância do planeamento estratégico para o empreendedor musical}

O mercado musical nunca mais foi o mesmo desde 2002, quando um programa de compartilhamento chamado Napster abriu a possibilidade de que os consumidores de música pudessem trocar arquivos em formato MP3 entre si de forma gratuita, segura e rápida. Embora o Napster original tenha fechado, os downloads gratuitos online continuam e as implicações disso até hoje interferem no mercado musical (KUSEK; LEONHARD, 2005).

A tecnologia, com o avanço da gravação digital, também possibilitou aos interessados adquirir equipamentos específicos de gravação, a preços acessíveis, permitindo que artistas não mais dependessem de estúdios para registrar seu trabalho. A partir daí a pessoa do músico independente passou cada vez mais a assumir todas as responsabilidades inerentes a uma carreira musical, atuando não só como artista, mas também como gestor.

O desenvolvimento da produção musical independente no país é marcado tanto por uma crise generalizada da indústria quanto por uma inédita organização da cena independente. Essa crise, que se vincula ao contexto geral da economia e a fatores específicos da indústria (como a pirataria digital e de formatos), parece estar afetando a capacidade das grandes gravadoras de atuar nos múltiplos segmentos do mercado, ampliando assim os espaços para a produção independente. (VICENTE, 2014, p. 2)

De acordo com Maurício Bussab (LA OTRA, 2017), diretor da Tratore, maior distribuidora de música independente no Brasil, a maior mudança começou quando os formatos de arquivo mudaram: com a possibilidade de baixar músicas gratuitamente, quem foi mais afetado, no geral, foram as gravadoras. No entanto, nos últimos anos, as formas de se consumir música e a forma de se investir no artista mudou. Hoje, as pessoas não querem ficar baixando conteúdo, elas consomem via streaming em plataformas como o Spotify ou o YouTube, e houve uma volta no interesse pela produção musical, tendo em vista que o fonograma tornou-se rentável novamente. Pela primeira vez na história, o negócio digital de música representa 50\% do negócio das 


\section{pontěditora}

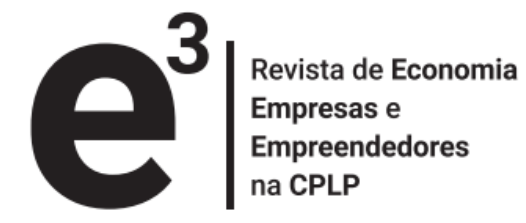

gravadoras e, após muitos anos de prejuízo em 2016, de acordo com a Federação Internacional da Indústria Fonográfica (IFPI), o mercado fonográfico teve um relevante crescimento (IFPI, 2016).

Segundo Salazar (2015, p. 181), “a direção estratégica de uma carreira artística é uma forma de direcionamento focado no futuro, atento às mudanças, a fim de manter o artista no mercado globalizado. É andar com os pés no chão, mas com a cabeça olhando para frente".

Portanto, o planeamento estratégico de uma carreira musical inicia-se com a análise SWOT (ou FOFA) e procura identificar as forças que atuam sobre o ambiente interno e externo desta carreira. Pontos fracos ou negativos são forças de natureza interna que prejudicam o rendimento e favorecem o rendimento. Ameaças são forças externas e, portanto, fora do controlo do artista, que podem prejudicar o seu desempenho. Oportunidades são situações externas que podem beneficiar a sua carreira. Essa análise ajuda a resumir os principais factos e as previsões que se encontram após as análises externa e interna. A partir disso, pode-se extrair uma série de declarações que identificam as questões estratégicas com que a organização se depara (SALAZAR, 2015).

Após essa análise ambiental pode-se elaborar planos estratégicos táticos e operacionais pertinentes ao negócio pretendido. Considera-se o plano estratégico como o resultado global desejado pelo artista. A sua execução fundamenta-se no longo prazo e evidenciam as operações necessárias para alcançar o resultado global. O plano tático define objetivos que ajudam o artista a cumprir a sua missão e concretizar a sua visão. Os objetivos devem ser específicos, desafiadores e determinados. O plano operacional tem por finalidade estabelecer metas que sirvam para estipular pontos de controlo, aferir resultados parciais em curto prazo e indicar os responsáveis.

O controlo do planeamento engloba uma atividade rotineira que, por meio de informações repassadas pelos membros da banda, ou público ou qualquer agente pertinente, possibilita tomar decisões sobre o real desempenho em comparação com o objetivo, os riscos detetados, o que ainda falta fazer e qual a necessidade de alterar o objetivo.

Por exemplo, se o número de shows está abaixo do esperado, pode ser um erro de estratégia. Também deve-se avaliar as impressões do público, o que eles acham sobre 


\section{pontěditora}

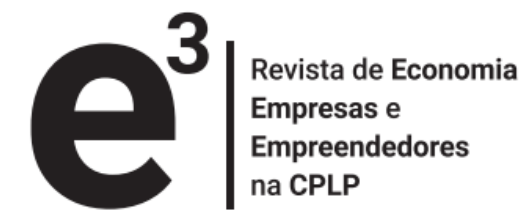

a qualidade do show. Outros agentes importantes são os músicos, técnicos, produtores e outros profissionais envolvidos no mercado. Muitas vezes eles observam outros ângulos de uma mesma situação. A comunicação, portanto, torna-se crucial nesta fase do planeamento estratégico (SALAZAR, 2015).

Concluindo, a indústria da música não é mais a mesma de há vinte anos atrás, até mesmo cinco anos atrás. Atualmente, artistas dirigem as suas carreiras da mesma forma que um empreendedor dirige uma startup, tudo isso sem ajuda de grandes corporações ou grandes gravadoras. A nova indústria da música gira em torno do faça você mesmo. Você escreve as músicas, grava e distribui para os fãs. Você mesmo é responsável por planear uma tournée, gerenciar e contactar seu público-alvo, criar sua estratégia de marketing. Tudo isso abre um amplo campo de oportunidades. Qualquer um pode se tornar bem-sucedido desde que possua as habilidades artísticas, a dedicação e a perseverança necessárias.

O modelo económico que norteou o negócio da música durante anos não é mais relevante. As gravadoras investiam pesadamente no desenvolvimento de carreiras, marketing e distribuição, assumindo os riscos. Um hit poderia justificar o investimento e permitir o desenvolvimento de outros artistas. Não é mais o caso. As gravadoras simplesmente não conseguem cobrir suas despesas com esse modelo. É preciso considerar os novos fluxos de receitas que podem ser gerados e trabalhar em um esforço coordenado para promovê-las. Criar a própria realidade é o jogo. A criatividade é um diferencial no momento de se definir um modelo económico e como ganhar dinheiro. A indústria em constante mutação está pronta para inovações, portanto, pensemos fora da caixa (KUSEK’S, 2014).

\section{Metodologia}

Entende-se como metodologia os procedimentos a serem seguidos na realização da pesquisa. Sua organização varia de acordo com as peculiaridades de cada pesquisa. Requer-se, no entanto, a apresentação de informações acerca de alguns aspectos (GIL, 2008).

De acordo com o proposto por Vergara (2007), o presente estudo teve o objetivo de desenvolver o Planeamento Estratégico para um empreendimento musical considerando-se os seguintes aspetos: quanto aos fins e quanto aos meios.

$\mathrm{e}^{3}$ - Revista de Economia, Empresas e Empreendedores na CPLP | Volume 4 | Número 1 


\section{pontěditora}

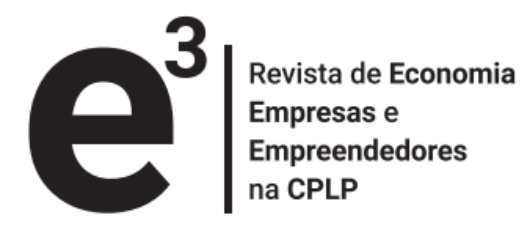

Quanto aos fins, trata-se de uma pesquisa exploratória, descritiva e aplicada. As pesquisas exploratórias têm como objetivo proporcionar maior conhecimento sobre um problema, no intuito de torná-lo mais explícito ou a elaborar hipóteses. O principal objetivo de tais pesquisas, portanto, consiste no aprimoramento de ideias ou a descoberta de intuições. Seu planeamento torna-se bastante flexível, de modo que permita a consideração dos mais variados aspetos relativos ao facto estudado. $\mathrm{Na}$ maioria dos casos, envolvem levantamento bibliográfico e entrevistas com pessoas que tiveram experiências práticas com o problema pesquisado e análise de exemplos pertinentes (GIL, 2008).

Dessa forma, o presente trabalho utilizou a pesquisa exploratória, pois tem como objetivo explorar e adquirir maior conhecimento sobre o mercado da música em Belo Horizonte, por meio de análise dos ambientes internos e externos de tal mercado, com o objetivo de propor soluções estratégicas para um empreendimento musical. Também se utilizou a pesquisa descritiva, por meio de uma entrevista, buscando-se observar fenómenos e entender os comportamentos, desejos, interesses e necessidades do mercado alvo.

\footnotetext{
As pesquisas descritivas têm como objetivo primordial a descrição das características de determinada população ou fenômeno ou, então, o estabelecimento de relações entre variáveis. São inúmeros os estudos que podem ser classificados sob este título e uma de suas características mais significativas está na utilização de técnicas padronizadas de coleta de dados, tais como questionário e a observação sistemática. (GIL, 2008, p. 42)
}

Segundo Vergara (2007), esta pesquisa caracteriza-se, por ser aplicada, já que foi criada a partir da necessidade de resolver problemas concretos em decorrência da falta de um Planeamento Estratégico.

Quanto aos meios, a pesquisa foi viabilizada por meio de estudo de caso, que Vergara (2007, p. 44) assim conceitua: "é o circunscrito a uma ou poucas unidades, entendidas essas como pessoa, família, produto, empresa, órgão público, comunidade ou mesmo país e tem caráter de profundidade e detalhamento".

De acordo com Gil (2008), os levantamentos abrangem um universo muito grande e, portanto, impossível de ser considerado em sua totalidade. Por essa razão, frequentemente se trabalha com amostras, ou seja, uma pequena parte do universo. Nos 


\section{pontěditora}

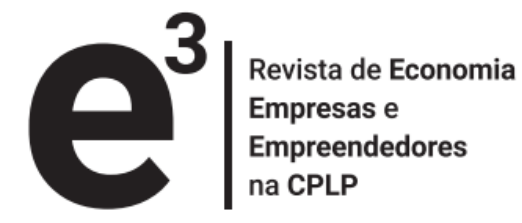

casos de a amostra ser rigorosamente selecionada, os resultados obtidos no levantamento tendem a aproximar-se bastante da realidade do universo.

O universo, no caso dessa pesquisa, foi restringido à empresa musical objeto do estudo, a banda Lugera. A amostra será censitária, tendo em vista que adotará a entrevista com um dos empreendedores da empresa. Para a pesquisa que embasou a análise da concorrência, optou-se por adotar amostra não probabilística, intencional, constituída exclusivamente de pessoas relacionadas ao ramo musical, preferencialmente músicos que possuam bandas com trabalho autoral. Como amostra foram selecionadas duas pessoas para a entrevista estruturada e cinquenta questionários respondidos via internet, voltados à análise concorrencial.

Para a pesquisa descritiva foi utilizada uma entrevista estruturada, em que o pesquisador seguiu um roteiro previamente estabelecido. Tal pesquisa permitiu que as repostas fossem comparadas com o mesmo conjunto de perguntas, refletindo as diferenças entre os entrevistados em relação ao assunto (MARCONI; LAKATOS, 2017).

Para a pesquisa exploratória foi utilizado um questionário, constituído por uma série ordenada de perguntas, que foram respondidas via internet, sem a presença do entrevistador.

O processo de análise de dados, tendo em vista a adoção de abordagem qualitativa e quantitativa, envolveu diversos processos: codificação das respostas, análise do conteúdo da entrevista, tabulação dos dados e cálculos estatísticos. Também envolveu a interpretação dos dados, que consiste em estabelecer a ligação entre os resultados obtidos com outros já conhecidos, e a partir desse ponto, ser capaz de desenvolver hipóteses acerca do assunto estudado (GIL, 2008).

Portanto, as análises dos dados provenientes das entrevistas foram interpretadas a fim de estabelecer conexões com o assunto do planeamento estratégico, por meio de uma análise qualitativa.

Os dados provenientes dos questionários foram codificados, tabulados e apresentados estatisticamente, por meio de gráficos e tabelas específicas para este fim.

Após análise dos dados, foram elaboradas as conclusões e propostas que abrangem o planeamento estratégico e um plano de ação para a empresa estudada. 


\section{pontěditora}

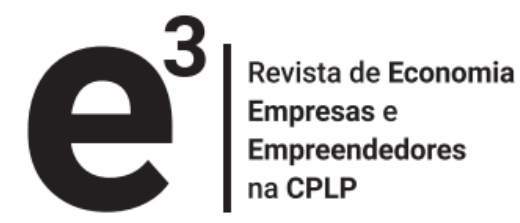

\section{Resultados e discussão}

A pesquisa deu-se por meio de um questionário voltado para análise da concorrência, no sentido de identificar a existência ou não de planeamento para a alavancagem da carreira musical, respondido por 49 pessoas, em sua maioria do sexo masculino, todas ligadas ao mercado musical independente de Belo Horizonte. Objetivando o aprofundamento para uma melhor elucidação do tema, foram realizadas entrevistas pessoais com três empreendedores da música, todos de Belo Horizonte, sendo um deles integrante da banda Lugera. As pesquisas foram realizadas durante os meses de julho e agosto de 2017. A seguir serão apresentados os resultados das duas pesquisas realizadas.

\subsection{Resultados da pesquisa}

As primeiras perguntas destinadas a compreender a realidade dos pesquisados foram relacionadas com a geração de renda com atividades musicais. A primeira pergunta buscou identificar a renda gerada com sua atividade musical e, caso positivo, qual seria esse valor. Os resultados seguem apresentados no Gráfico 1.

Gráfico 1 - Recursos financeiros gerados com a música

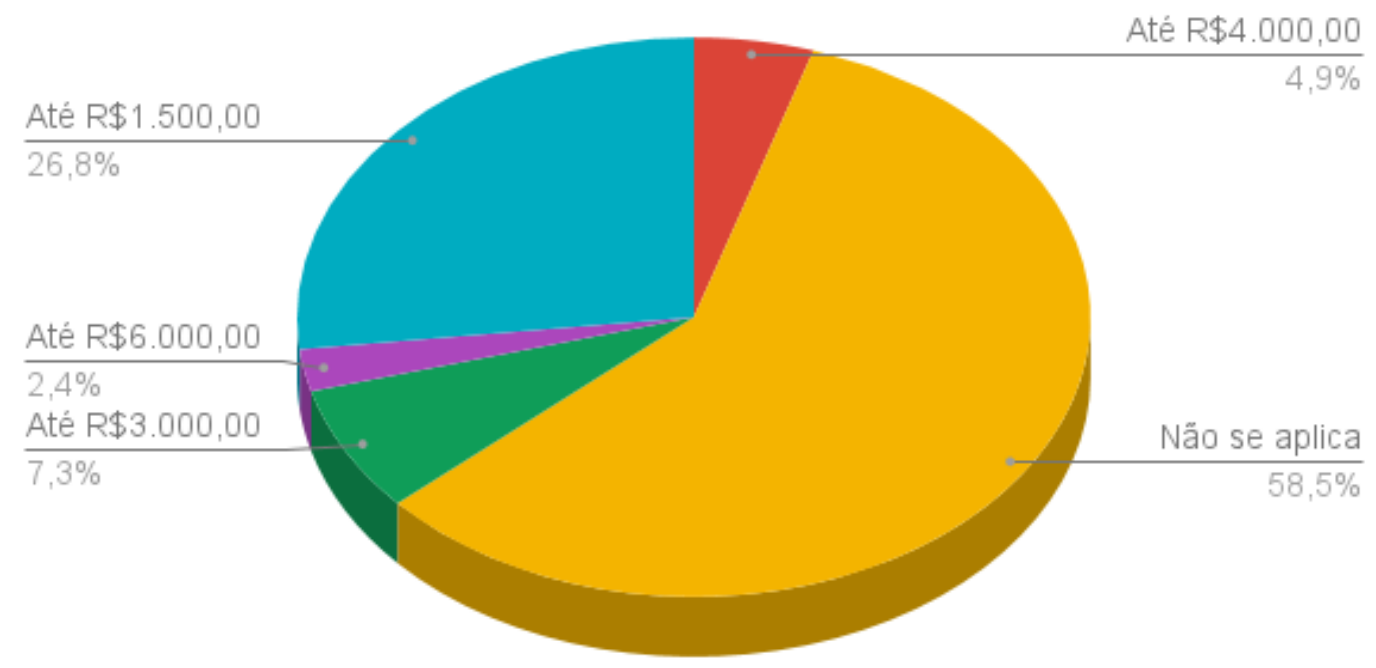

Fonte: Dados da pesquisa (2017)

$\mathrm{e}^{3}$ - Revista de Economia, Empresas e Empreendedores na CPLP | Volume 4 | Número 1 


\section{pontěditora}

Constatou-se que um pouco mais da metade $(58,5 \%)$ dos pesquisados não geram nenhum recurso financeiro com sua atividade musical. Dos $41,5 \%$ restantes que afirmaram obter renda por meio da atividade musical, 26,8\% conseguem atingir uma renda mensal de no máximo $\mathrm{R} \$ 1.500,00$, sendo esse percentual gradativamente diminuído à medida em que a faixa de renda aumenta. Pode-se concluir, pela análise desses dados, que a música não representa um trabalho rentável para a maioria daqueles que atuam nesse mercado e que apenas uma pequena parcela dos profissionais atinge um nível de renda razoável. Dentro de vários factores como o talento, capacidade técnica e nível de comprometimento, o sucesso financeiro provavelmente envolve um planeamento prévio, realizado de forma criteriosa de maneira a potencializar os pontos fortes identificados na análise do ambiente.

O Gráfico 2 buscou avaliar o grau de satisfação dos empreendedores da música em relação ao seu trabalho.

Gráfico 2 - Grau de satisfação com o próprio trabalho

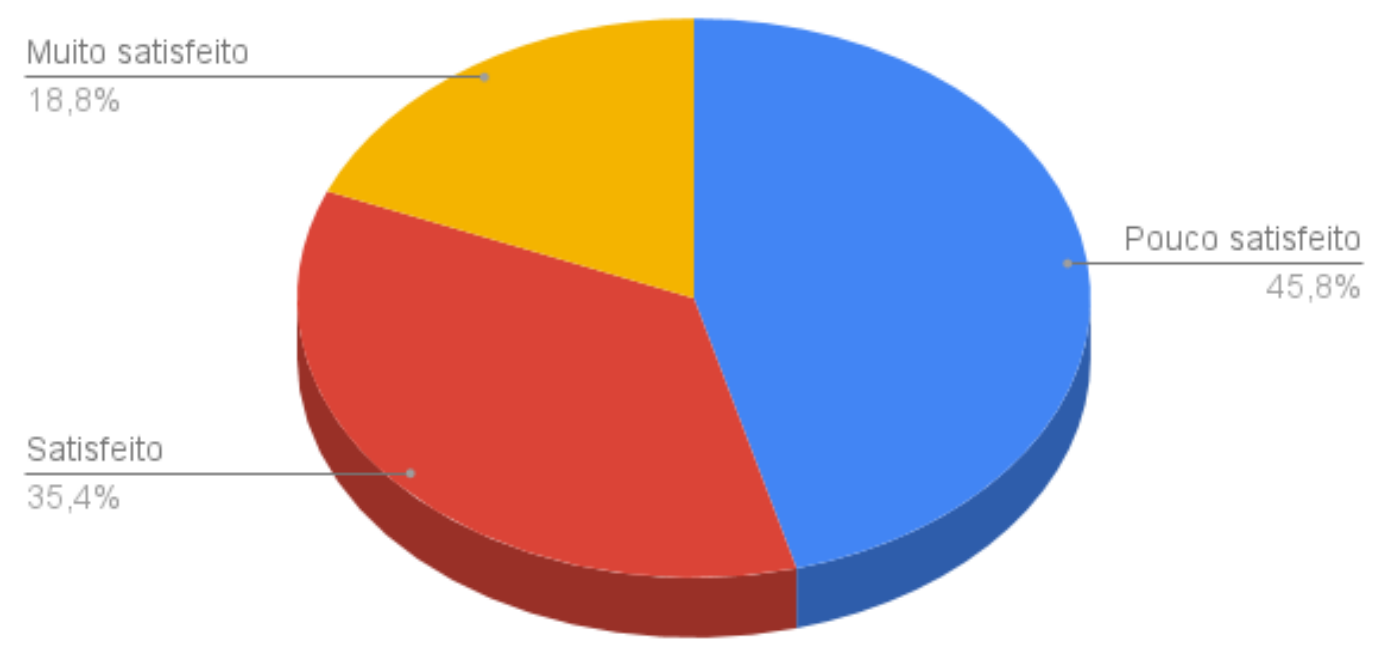

Fonte: Dados da pesquisa (2017)

$\mathrm{e}^{3}$ - Revista de Economia, Empresas e Empreendedores na CPLP | Volume 4 | Número 1 


\section{pontěditora}

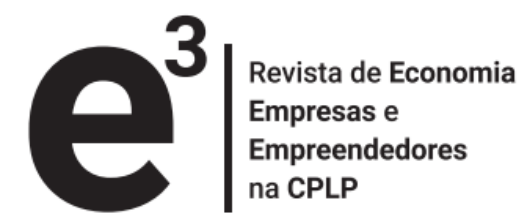

O resultado apresentado no Gráfico 2 chamou à atenção por constatar que quase metade da amostra pesquisada $(45,8 \%)$ está pouco satisfeita. Um dos motivos dessa insatisfação pode estar relacionado à falta de retorno financeiro constatada anteriormente, e uma consequente desilusão com o mercado musical. Essa condição pode estar associada ao entendimento de Vicente (2014) que sugere que o aumento da produção musical independente no país é marcado por duas situações distintas: primeiro, pela crise generalizada da indústria e, segundo, por uma incomum organização da cena independente. Ainda, de acordo com Dolabela (1999), alguns dos profissionais do ramo podem não apresentar como característica serem trabalhadores incansáveis, que realmente gostam do que fazem, trabalhando dia e noite, mas sempre com a consciência da qualidade que deve impor às suas tarefas, visando resultados e não ao trabalho em si. O resultado pode representar que uma grande parcela dos artistas não considera a música como um empreendimento, mas simplesmente uma atividade de entretenimento sem compromisso e que, portanto, não buscam posicionar-se estrategicamente de maneira a aproveitar as oportunidades oferecidas pelo aumento da produção musical e pela maior organização da cena independente, objetivando atingirem resultados melhores.

A próxima série de perguntas pretendeu analisar a atitude dos empreendedores musicais perante o mercado externo. O Gráfico 3 apresenta o comparecimento aos shows de outras bandas (concorrentes) e o Gráfico 4 apresenta a presença nos diversos eventos, seminários e encontros relacionados ao mercado da música, todos bons locais para se adquirir uma visão ou perceção sobre as tendências do setor, possibilitando a elaboração de estratégias baseadas em previsões sobre o futuro do mesmo. 
ponteditiora $\quad \mathbf{e}^{3} \mid$

Gráfico 3 - Frequência em shows de outras bandas/artistas

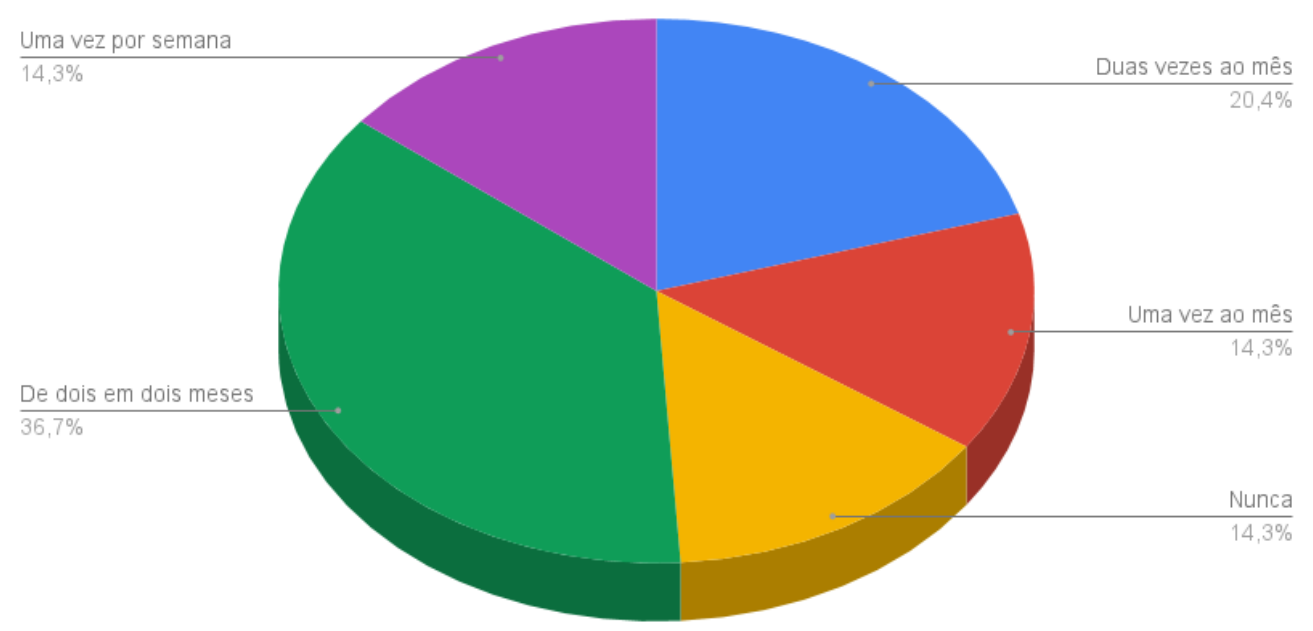

Fonte: Dados da pesquisa (2017)

O resultado aponta que uma pequena parte $(14,3 \%)$ dos pesquisados possuem uma rotina semanal de frequentar shows. Além disso, somando-se os que nunca frequentam e os que muito pouco frequentam (de dois em dois meses), obtém-se um percentual de $51 \%$, o que confirma uma falta de interesse de grande parte dos empreendedores de estar em contacto com outros agentes do mercado. Tal comportamento pode comprometer bastante a tomada de decisões num momento em que se busca compreender quais as tendências do setor, não sendo possível perceber os movimentos do mercado sem estar em contacto com ele. Uma análise SWOT, por exemplo, ficaria bastante reduzida a uma análise interna de forças e fraquezas, sem ser possível identificar forças externas, fora do controlo do artista ou oportunidades que possam beneficiar uma carreira, o que compromete bastante a capacidade de responder às questões estratégicas que se apresentam.

$\mathrm{e}^{3}$ - Revista de Economia, Empresas e Empreendedores na CPLP | Volume 4 | Número 1 


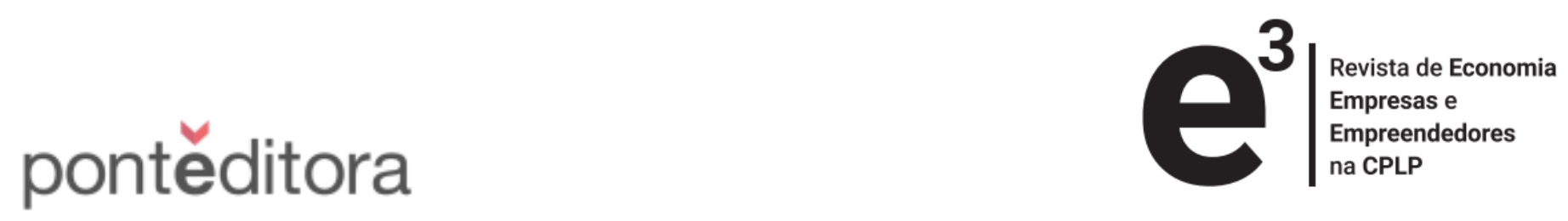

Gráfico 4 - Frequência em encontros, palestras, seminários ou feiras relacionados ao mercado musical.

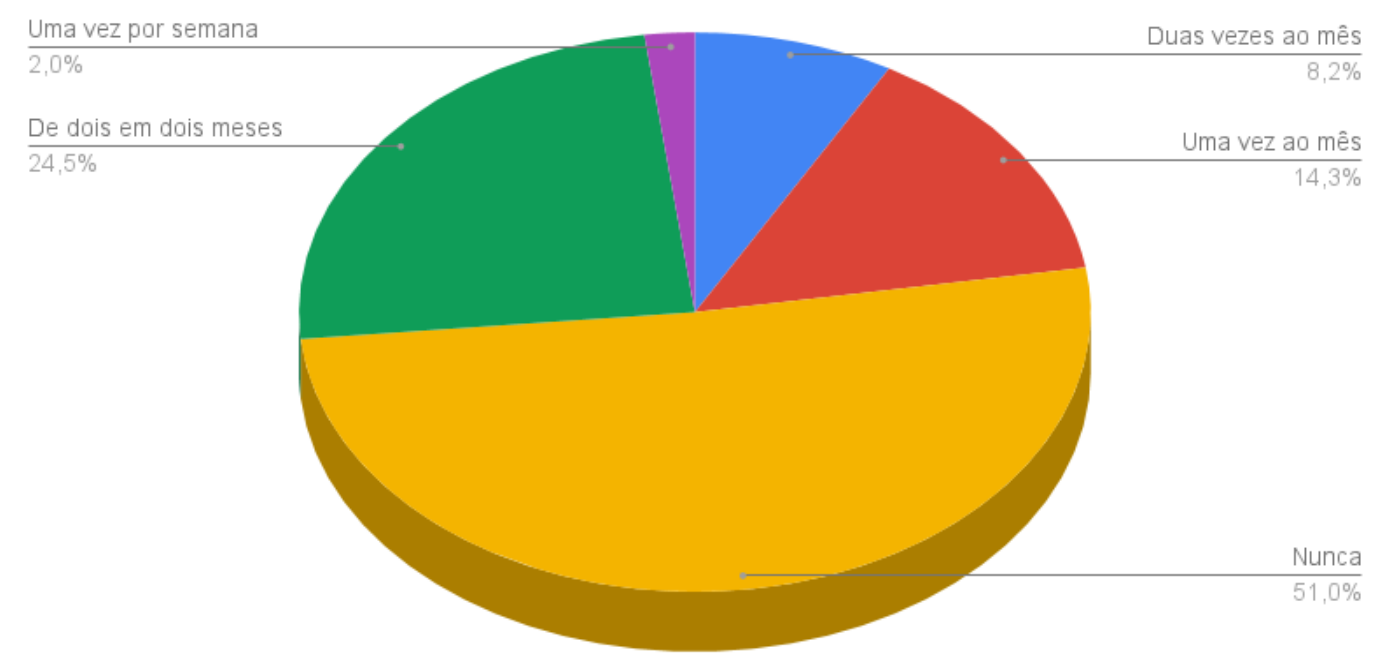

Fonte: Dados da pesquisa (2017)

Nota-se na análise do Gráfico 4 que $51,0 \%$ dos entrevistados nunca participaram de eventos relacionados o setor musical. Na opinião de Hamel e Prahalad (1995), existe algo mais na previsão do futuro de um setor do que simples lampejos ofuscantes de insight. A previsão do futuro do setor baseia-se em perceções profundas das tendências da tecnologia, demografia, regulamentação e estilos de vida que podem ser utilizados para reescrever as regras do setor e criar um novo diferencial competitivo. Embora a compreensão das implicações potenciais dessas tendências exija criatividade e imaginação, qualquer visão que não se baseie em fundamentos factuais sólidos, possivelmente, será uma visão fantasiosa. Assim sendo, a melhor maneira de se obter uma boa visão do mercado musical consiste em relacionar-se com outras pessoas do mesmo setor. De acordo com o Gráfico 4, este não é um comportamento comum entre os entrevistados, revelando mais uma vez, a falta de uma estratégia para melhor entender o comportamento do ambiente externo.

Objetivando compreender como se dá o planeamento dos empreendimentos musicais, perguntou-se como é realizada a marcação de shows. Se ocorre por meio de 


\section{pontěditora}

um planejamento anterior ou simplesmente conforme as oportunidades se apresentem.

O Gráfico 5 apresenta os resultados.

Gráfico 5 - Planeja shows ou marca conforme oportunidade

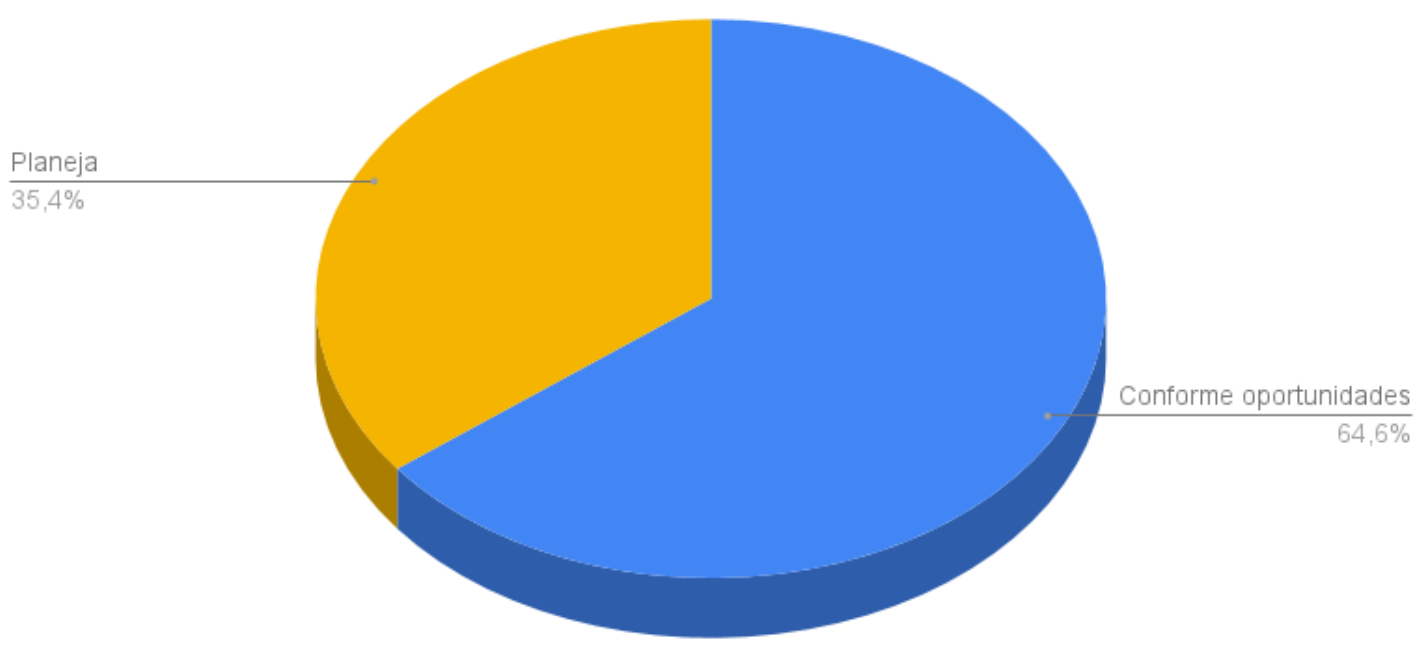

Fonte: Dados da pesquisa (2017)

A maioria dos pesquisados $(64,6 \%)$ afirmou não realizar planeamento de seus shows, agendando-os conforme surgem as oportunidades. Tal resultado demonstra, no que se refere a busca por melhores oportunidades, que a maioria dos empreendedores não adota uma visão estratégica em relação aos seus shows. Um dos eixos principais do mercado da música são as apresentações ao vivo, sendo de suma importância investir no planeamento a fim de atingir o público-alvo, definido e conseguir melhores resultados.

Esse entendimento é reforçado pelo Entrevistado X1 quando afirma que:

O principal ponto forte acredito ser a performance da banda ao vivo, não por sermos músicos fenomenais, somos bons o suficiente, mas o principal é que o público ao ver nossa apresentação consegue relacionar nosso discurso com a música. Ao definirmos muito bem nosso público alvo, planejamos nossos shows de forma a sempre nos apresentarmos para públicos que buscam nosso produto, e portanto, o retorno que conseguimos sempre é muito melhor. 


\section{pontěditora}

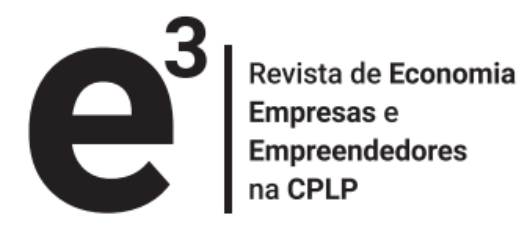

O Gráfico 6 apresenta os resultados relativos à realização de reuniões com colaboradores a fim de se tratar exclusivamente do planeamento.

Gráfico 6 - Realiza reuniões para tratar de planeamento

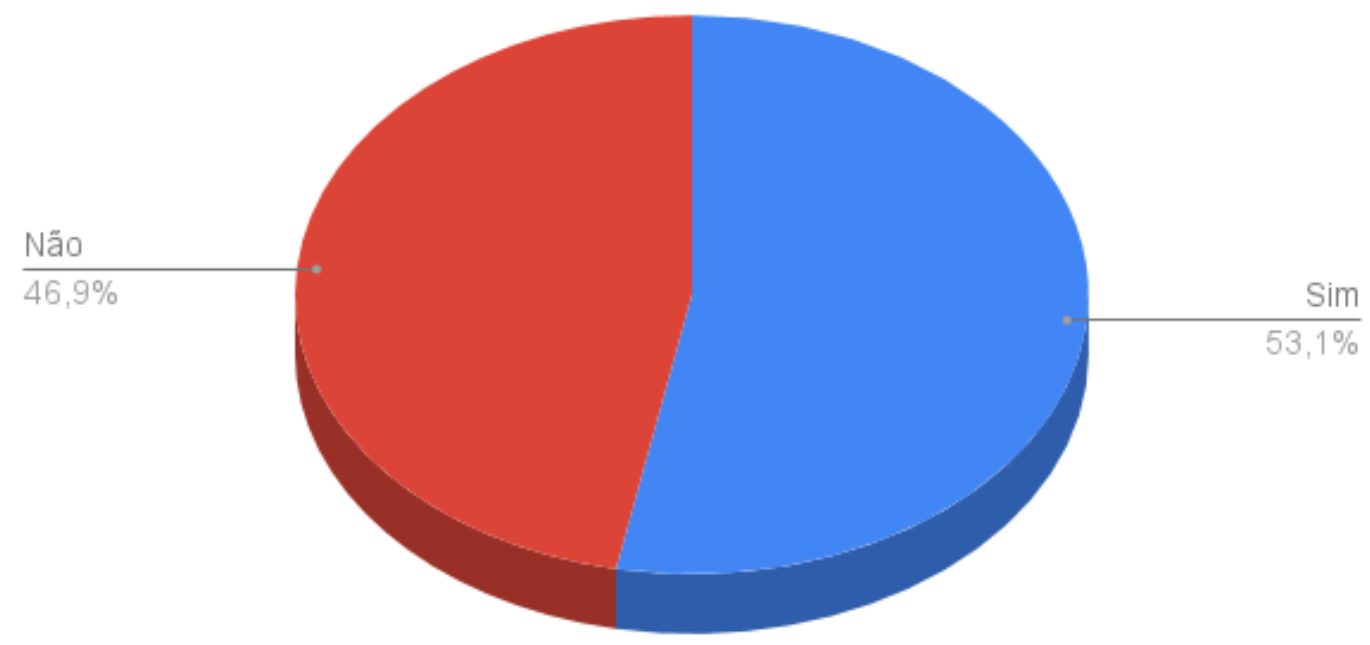

Fonte: Dados da pesquisa (2017)

O Gráfico 6 mostra que um pouco mais da metade dos entrevistados $(53,1 \%)$ realizam encontros com o objetivo de discutir ações de planeamento. Isso demonstra que ainda grande parte dos empreendedores não se preocupa com o planeamento, ficando focados somente nos aspetos artísticos e musicais do empreendimento em detrimento dos aspetos relacionados à gestão do negócio. Tal abordagem representa uma visão já ultrapassada de uma carreira artística, uma vez que hoje o empreendedor musical representa o principal motor de sua carreira.

O modelo de investimento também mudou. Atualmente, os lançamentos da maioria dos discos acontece por meio de pequenas gravadoras ou diretamente pelos artistas. Os grandes grupos não investem mais em promessas, preferem investir em carreiras consolidadas, com púbico formado. Isso representa mais responsabilidades para o artista, uma vez que sua gestão de carreira não pode ser mais delegada, forçando o músico a agir como um empreendedor. Para tanto, deve-se trabalhar duro. Ter visão empreendedora torna-se uma competência fundamental para o músico ser capaz de 


\section{pontěditora}

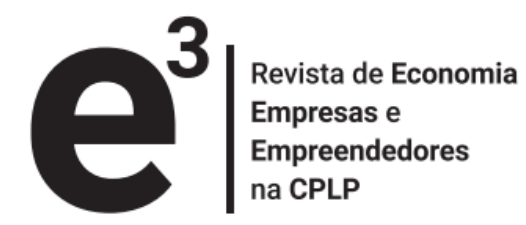

traçar estratégias adequadas. O planeamento representa o segredo para atingir bons resultados (LA OTRA, 2017).

Buscando identificar na concorrência a perceção dos mesmos no que diz respeito ao seu foco de atuação e onde pretende chegar com o negócio, perguntou-se se existe missão e visão definidas. Nota-se que um pouco menos da metade $(45,8 \%)$ dos pesquisados não possuem uma missão para o seu negócio, o que representa que não foram estabelecidas as diretrizes desse trabalho. A missão consiste na identificação da razão pela qual o trabalho existe e sua inexistência aponta um grave sinal de que grande parte dos pesquisados não possuem um propósito em suas carreiras. As carreiras sem propósito não podem sobreviver num mercado competitivo.

Em relação aos 54,2\% restantes que declaram possuir uma missão, poucos deles souberam definir adequadamente a sua razão de existir. Na sua maioria, declaram como sua missão o desejo de ser sustentável, divertir o público, entreter ou resgatar algum estilo musical. Mais uma vez, a falta de uma visão estratégica fica clara, uma vez que em nenhuma das respostas foram citados aspetos que demonstrem um claro posicionamento perante o público-alvo e o mercado, como ser referência no setor ou em determinado nicho, aspetos que demonstrem uma razão de existir mais definida e profunda.

Um bom exemplo, a fim de comparação, entre uma visão bem definida e outra nem tanto, pode ser observado por meio das entrevistas. Observem a definição de visão apontada pelo Entrevistado X2, quando afirma que, "Minha visão é proporcionar a todos os envolvidos uma interação na qual todos compartilhem a mesma emoção".

Para o Entrevistado X1, “A missão do meu empreendimento é fazer rock brasileiro pesado com identidade e competência, buscando alcançar o grande mercado da música sendo referência no meu nicho".

O Entrevistado X1 soube definir bem a sua missão, explicitando pontos fortes do seu trabalho (identidade e competência), aspetos empresariais (empreendimento), além de definir claramente a razão para tal empreendimento existir (alcançar o grande mercado da música, sendo referência no meu nicho). Já o Entrevistado X2 focou em aspetos mais pessoais e emocionais, onde define a sua razão de existir como a interação entre o seu trabalho e o público ao redor da mesma emoção. Uma missão, portanto, nem um pouco definida e não voltada para o mercado. 


\title{
pontěditora
}

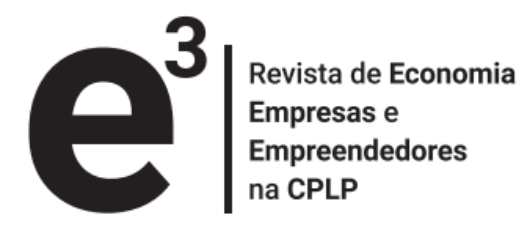

Em relação à visão, mais uma vez, observou-se que os pesquisados, mesmo respondendo positivamente que possuem visão, não conseguiram apresentar previsões que se baseiem em tendências mercadológicas, o que dificulta bastante perceber para onde as coisas vão, quais são as forças que se opõem aos objetivos da organização, como lidar com elas, quais são as oportunidades que se abrem, como aproveitá-las bem. Novamente observa-se uma falta de visão estratégica dos empreendedores musicais, em sua maioria.

Observa-se, ao confrontar as respostas de ambos os entrevistados, que um deles, Entrevistado X1, possui uma visão estratégica mais bem definida, com os pontos fortes e fracos, e as ameaças e oportunidades mais de acordo com o mercado o que permite elaborar as suas ações, buscando um diferencial em relação aos seus concorrentes. Segundo o Entrevistado X1:

\begin{abstract}
Algumas ações realizadas pela banda podem ser citadas: ampliação do público-alvo com apresentações fora de Belo Horizonte, busca por recursos via Lei de Incentivo, inclusive com projetos aprovados, estruturação de uma base de fãs, busca por parcerias e foco direcionado à um nicho específico da música. Todas ações refletem em nos resultados alcançados, mais expressivos e concretos do que o da concorrência.
\end{abstract}

É importante ressaltar que o Entrevistado X2 possui grande um talento musical, sendo um excelente instrumentista, entretanto, os seus melhores resultados não são concretos. De acordo com as suas respostas, curtas e muitas vezes muito subjetivas, a sua carreira não está em conformidade com a de empreendedor musical, atento à necessidade de se possuir uma visão estratégica do seu setor.

\section{Considerações finais}

O objetivo desta pesquisa consistiu em desenvolver um planeamento estratégico para um empreendimento musical (Lugera), a fim de se impulsionar a carreira de tal empreendimento.

A música talvez seja uma das expressões artísticas mais presentes no nosso cotidiano, contemplando toda a sociedade, sem distinção de classes sociais, local ou idade. Diferentemente do que um leigo possa imaginar, a indústria musical atual não se concentra somente no chamado mainstream ou no grande mercado, a corrente principal. 


\section{pontěditora}

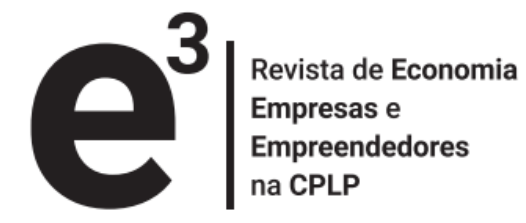

As oportunidades apresentam-se para todos, dos músicos independentes às grandes corporações ligadas às vendas digitais. Vários artistas, focados nos seus nichos de mercado, literalmente micromercados de música, obtêm um considerável sucesso nas suas carreiras, atingindo a autossuficiência nos seus empreendimentos.

A utilização de técnicas para a gestão de carreiras, marketing, construção de marcas e oferta de conteúdo, serviços e produtos que proporcionem experiências e sentimentos diferenciados para o público, pode representar um grande diferencial em trabalhos artísticos que buscam estabelecer-se como empreendimentos de sucesso.

Num mercado musical cada vez mais competitivo, profissionais não capacitados tendem a limitar as suas possibilidades de sucesso, enfraquecendo a cena musical local. Dos inúmeros projetos independentes lançados ligados à área musical, poucos conseguem conquistar, minimamente, um público disposto a apoiar as suas carreiras. Tal facto deve-se, na maioria dos casos, à falta de um planeamento estratégico por parte dos empreendedores, que muitas vezes nem sequer conseguem definir o seu públicoalvo.

Os resultados da pesquisa revelam uma grande carência de uma visão estratégica dos empreendedores musicais e, como consequência, uma redução das possibilidades de obter-se melhores resultados, sejam financeiros ou de satisfação, aos seus agentes. Portanto, um planeamento estratégico aplicado a um empreendimento musical pode ser um grande diferencial para artistas interessados em obter retornos acima da média, assim como ser um instrumento para a gestão de carreiras empreendedoras de sucesso.

Algumas limitações encontradas para a realização do trabalho foram o número de pessoas disponíveis para responder o questionário que, no caso desta pesquisa, ficou bem próximo do mínimo exigido, porém, esperava-se maior envolvimento por parte de pessoas que compõem o cenário da música independente na cidade. Além disso, grande número de respostas fugiram totalmente daquilo que era esperado, demonstrando que para muitos dos entrevistados o assunto Planeamento Estratégico é totalmente desconhecido.

Diante disso, com o objetivo de atender a proposta inicial do estudo, foi desenvolvido o plano estratégico para a banda Lugera, tendo como alvo impulsionar a carreira musical independente da banda. 


\section{pontěditora}

Como proposta, apresenta-se o planeamento estratégico a ser adotado pela Banda Lugera, apresentando uma análise do ambiente organizacional, elaboração dos princípios norteadores (valores, missão e visão) da banda, formulação dos objetivos estratégicos e elaboração de um plano de ação a ser aplicado no desenvolvimento do empreendimento musical.

\subsection{Análise do ambiente}

A primeira etapa do planeamento estratégico consiste num processo de monitoração do ambiente organizacional, também conhecido como análise SWOT. De acordo com Certo e Peter (2005), o ambiente organizacional compreende todos os factores, internos e externos, que podem influenciar o progresso alcançado por meio da realização dos objetivos.

Quadro 1 - Análise SWOT da banda Lugera

\begin{tabular}{|c|c|c|}
\hline & Positivos & Negativos \\
\hline $\begin{array}{l}\text { Factores } \\
\text { internos }\end{array}$ & 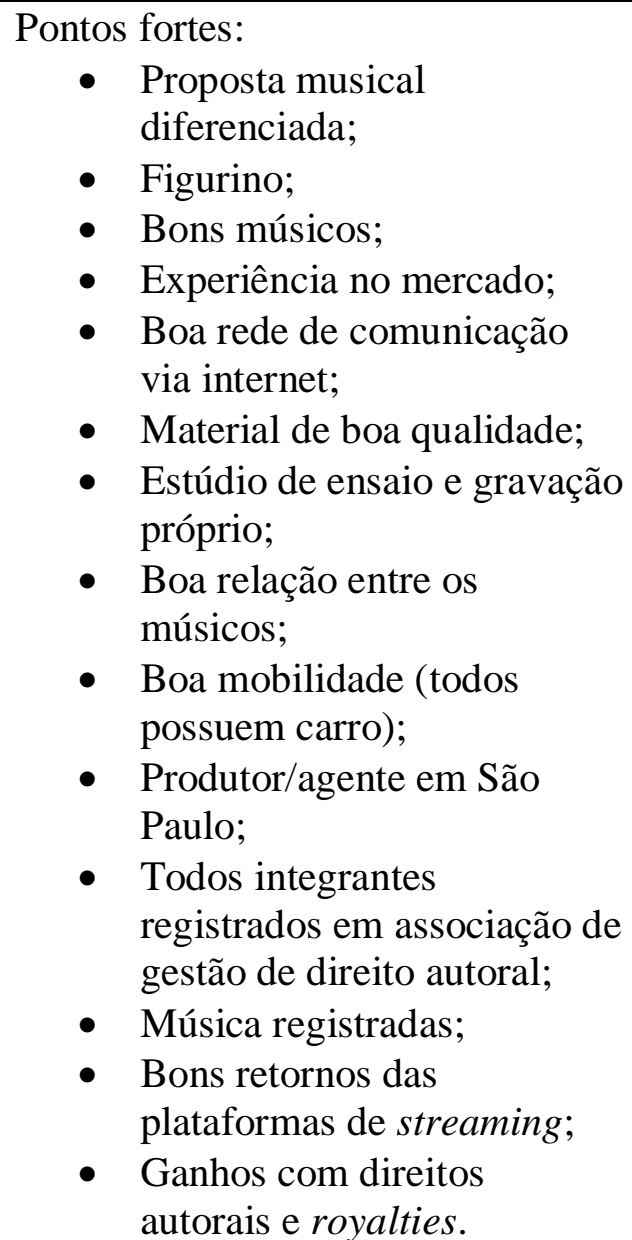 & $\begin{array}{l}\text { Pontos fracos: } \\
\text { - Recursos financeiros } \\
\text { limitados; } \\
\text { - } \text { Banda com pouco tempo de } \\
\text { formação; } \\
\text { - Poucos shows realizados; } \\
\text { - Nenhuma parceria em Belo } \\
\text { - Horizonte; } \\
\text { - Nenhum contacto com a } \\
\text { imprensa local; } \\
\text { - } \text { Desconhecimento da marca; } \\
\text { - Nalta de distribuidora/selo; } \\
\text { venda além das músicas; } \\
\text { - Perda de parte do público } \\
\text { brasileiro devido às músicas } \\
\text { - } \text { serem em inglês; } \\
\text { Dificuldade em produzir } \\
\text { vídeos com maior frequência. }\end{array}$ \\
\hline
\end{tabular}

$\mathrm{e}^{3}$ - Revista de Economia, Empresas e Empreendedores na CPLP | Volume 4 | Número 1 


\begin{tabular}{|c|c|c|}
\hline $\begin{array}{l}\text { Factores } \\
\text { externos }\end{array}$ & $\begin{array}{l}\text { Oportunidades: } \\
\text { - } \text { Aumento da popularidade } \\
\text { das plataformas de } \\
\text { streaming com o aumento } \\
\text { das vendas digitais; } \\
\text { - } \text { Organização da cena } \\
\text { independente com cada vez } \\
\text { mais espaços para bandas } \\
\text { autorais; } \\
\text { - Oportunidades em teatros do } \\
\text { SESC e SENAI, em vários } \\
\text { estados, que geram } \\
\text { excelentes ganhos com } \\
\text { direitos autorais; } \\
\text { Licenciamento de músicas } \\
\text { para filmes e comerciais; } \\
\text { Novos editais de Lei de } \\
\text { Incentivo; } \\
\text { Aumento do número de } \\
\text { concursos para bandas } \\
\text { autorais; } \\
\text { Poucos concorrentes com } \\
\text { propostas similares. }\end{array}$ & $\begin{array}{l}\text { Ameaças: } \\
\text { - Crise económica e } \\
\text { consequente redução de gastos } \\
\text { com entretenimento e música; } \\
\text { - Mudanças em leis } \\
\text { relacionadas ao direito } \\
\text { autoral; } \\
\text { - Preconceito de certa parcela } \\
\text { do público com o segmento } \\
\text { pop/eletrónico; } \\
\text { Aumento dos custos com } \\
\text { equipamentos e acessórios } \\
\text { relacionados a música. }\end{array}$ \\
\hline
\end{tabular}

Fonte: Elaborado pelo autor (2017)

\subsection{Estabelecimento das diretrizes organizacionais}

Nesta segunda etapa, tendo por base a entrevista com um dos integrantes da banda Lugera, sugerem-se os princípios norteadores do empreendimento (valores, missão e visão). Valores "são os balizamentos para o processo decisório e o comportamento da empresa no cumprimento da sua missão" (VASCONCELOS; PAGNONCELLI, 2001, p. 31).

Os valores da banda Lugera são:

- Autenticidade: a base para um trabalho coeso inclui liberdade criativa, coerência nas ações e espontaneidade.

- Interatividade: o convívio e a troca de experiências com outros artistas gera um dinamismo favorável à cena musical.

- Humildade: característica das pessoas que sabem assumir as suas responsabilidades, sem arrogância, prepotência ou soberba. 
- Empreendedorismo: agregar valor, saber identificar oportunidades e transformálas em um negócio lucrativo.

Missão "é a razão de existir da empresa no seu negócio" (VASCONCELOS; PAGNONCELLI, 2001, p. 31). A missão da banda Lugera é “fazer música pop que leve entretenimento de qualidade ao grande público, de maneira profissional e criativa a fim de se tornar referência no cenário pop/eletrônico nacional".

Visão "é a explicitação do que se visualiza para a empresa" (VASCONCELOS; PAGNONCELLI, 2001, p. 31). A visão da banda Lugera é "estabelecer um trabalho auto sustentável dentro do nicho específico da música pop eletrônica, conquistando o reconhecimento do público a nível nacional".

\subsection{Formulação da estratégia e plano de ação}

Nesta etapa apresentam-se os objetivos definidos a partir das análises realizadas e seus respectivos planos de ação.

1. Recursos financeiros da banda. Estabelecer um fundo abastecido por contribuições mensais no valor de cem reais para custear quaisquer despesas inerentes ao projeto. Essa proposta já poderá ser adotada de imediato.

2. Contacto com a imprensa. Realizar levantamento de todos os contactos disponíveis da área jornalística, que podem ser obtidos com consulta aos expedientes dos jornais, buscas via internet, ligações telefónicas ou até mesmo encontros presenciais. A partir do levantamento, será criado um press release que será enviado a todos os contactos. Seria interessante também que a banda contratasse um profissional de assessoria de imprensa para conseguir algumas aparições na mídia. Esse item deverá ser realizado até o final de 2017.

3. Shows. Nessa área a banda pretende atuar em duas localidades, em Belo Horizonte fomentando a cena local, e em São Paulo, por meio do produtor/agente da banda. Para Belo Horizonte a proposta será realizar um show numa casa mais conceituada no cenário autoral, por exemplo a "Autêntica", localizada na Savassi. Para tanto, deverá entrar em contacto com os produtores da casa e buscar oportunidades para o primeiro semestre de 2018. Para São 


\section{pontěditora}

Paulo, o objetivo consiste em conseguir oportunidades em locais que ofereçam bons cachês e retornos com direitos autorais. Para tanto, o produtor/agente da banda mantém contato com o SESC, que possui várias unidades na cidade e uma agenda de shows constante. $\mathrm{O}$ objetivo será fazer uma série de shows na cidade a partir do segundo semestre de 2018.

4. Parceria com um selo de distribuição, de preferência internacional. Tal tarefa também será de responsabilidade do produtor/agente da banda e o prazo para a realização é até junho de 2018.

5. Parceria com algum artesão/designer para a produção de produtos exclusivos da banda. Um produto diferenciado, por exemplo, seria uma miniatura das máscaras usadas pelos músicos nas suas apresentações, que poderiam ser vendidas como pingentes, brincos, esculturas, enfim, uma série de produtos que seriam diferenciados pelo design. Além disso, seriam implementadas lojas virtuais nas páginas da banda e na fã page no Facebook. O objetivo será de até junho de 2018 estar com tudo funcionando e oferecer um mix de pelo menos 5 produtos.

6. Lançar um single e um videoclipe até o final do ano. Tal tarefa encontra-se em realização, a música já foi gravada, o cinegrafista já está acertado, falta, no momento, definir a locação e a data das filmagens e realizar a adição do material. Prazo até o início de 2018.

O Quadro 2, a seguir, apresenta o plano de ação elaborado para a banda Lugera, especificando a necessidade de atuação (ações), justificativas, responsáveis, prioridades, área de atuação, atividades necessárias para implantação e custos. 


\section{pontěditora}

Quadro 2 - Plano de ação

\begin{tabular}{|c|c|c|c|c|c|c|}
\hline O quê? & Para quê? & Quem? & Quando? & Onde? & Como? & Quanto \\
\hline $\begin{array}{l}\text { Necessidade } \\
\text { de atuação } \\
\text { (Ação) }\end{array}$ & $\begin{array}{l}\text { Justificativa / } \\
\text { benefícios }\end{array}$ & Responsável & $\begin{array}{l}\text { Prioridad } \\
\mathrm{e}\end{array}$ & Qual área & $\begin{array}{l}\text { Atividades necessárias p/ } \\
\text { implementar }\end{array}$ & $\begin{array}{l}\text { Recursos } \\
\text { financeiros } \\
\text { necessários }\end{array}$ \\
\hline $\begin{array}{l}\text { Fundo de } \\
\text { reserva }\end{array}$ & $\begin{array}{l}\text { Despesas } \\
\text { futuras }\end{array}$ & Lucas & $30 / 09 / 17$ & Banco & $\begin{array}{l}\text { Depósitos mensais de } \\
\mathrm{R} \$ 100,00 \text { para cada membro } \\
\text { da banda }\end{array}$ & $\mathrm{R} \$ 100,00$ \\
\hline $\begin{array}{l}\text { Contacto com } \\
\text { imprensa }\end{array}$ & $\begin{array}{l}\text { Divulgação do } \\
\text { trabalho }\end{array}$ & Geraldo & $30 / 12 / 17$ & $\begin{array}{l}\text { Belo } \\
\text { Horizonte }\end{array}$ & $\begin{array}{l}\text { Consulta aos expedientes dos } \\
\text { jornais, buscas via internet, } \\
\text { ligações telefónicas ou até } \\
\text { mesmo encontros presenciais. }\end{array}$ & - \\
\hline $\begin{array}{l}\text { Formulação } \\
\text { de Press } \\
\text { Release }\end{array}$ & $\begin{array}{l}\text { Divulgação do } \\
\text { trabalho }\end{array}$ & Lucas & $30 / 12 / 17$ & $\begin{array}{l}\text { Belo } \\
\text { Horizonte }\end{array}$ & $\begin{array}{l}\text { Elaborando um texto sobre a } \\
\text { banda e escolhendo fotos para } \\
\text { divulgação. }\end{array}$ & - \\
\hline $\begin{array}{l}\text { Contratação } \\
\text { de assessor de } \\
\text { imprensa }\end{array}$ & $\begin{array}{l}\text { Divulgação do } \\
\text { trabalho }\end{array}$ & Geraldo & $30 / 12 / 17$ & $\begin{array}{l}\text { Belo } \\
\text { Horizonte }\end{array}$ & $\begin{array}{l}\text { Procurando um profissional } \\
\text { através de contactos. }\end{array}$ & $\mathrm{R} \$ 3.000,00$ \\
\hline Shows BH & $\begin{array}{l}\text { Divulgação do } \\
\text { trabalho, } \\
\text { conquistar } \\
\text { mais público }\end{array}$ & Lucas & $30 / 02 / 18$ & $\begin{array}{l}\text { Belo } \\
\text { Horizonte }\end{array}$ & $\begin{array}{l}\text { Através de contacto com } \\
\text { produtores de casas de shows } \\
\text { de Belo Horizonte. }\end{array}$ & - \\
\hline Shows SP & $\begin{array}{l}\text { Divulgação do } \\
\text { trabalho, } \\
\text { conquistar } \\
\text { mais público }\end{array}$ & Ricardo & $30 / 04 / 18$ & ، & $\begin{array}{l}\text { Através de contacto com } \\
\text { produtores de casas de shows } \\
\text { e espaços culturais de São } \\
\text { Paulo. }\end{array}$ & - \\
\hline $\begin{array}{l}\text { Selo de } \\
\text { distribuição }\end{array}$ & $\begin{array}{l}\text { Divulgação do } \\
\text { trabalho, } \\
\text { conquistar } \\
\text { mais público, } \\
\text { realizar mais } \\
\text { vendas de } \\
\text { fonogramas }\end{array}$ & Ricardo & $30 / 04 / 18$ & São Paulo & $\begin{array}{l}\text { Através do produtor/agente } \\
\text { que possui contatos com selos. }\end{array}$ & $\mathrm{R} \$ 400,00$ \\
\hline
\end{tabular}




\section{pontěditora}

\begin{tabular}{|l|l|l|l|l|l|l|}
\hline $\begin{array}{l}\text { Produtos } \\
\text { exclusivos/ } \\
\text { loja virtual }\end{array}$ & $\begin{array}{l}\text { Obter renda } \\
\text { com produtos } \\
\text { exclusivos, } \\
\text { fidelizar o } \\
\text { público }\end{array}$ & $\begin{array}{l}\text { Geraldo/ } \\
\text { Lucas }\end{array}$ & $30 / 05 / 18$ & $\begin{array}{l}\text { Belo } \\
\text { Horizonte }\end{array}$ & $\begin{array}{l}\text { Através de parcerias com } \\
\text { artesãos, designers e estilistas }\end{array}$ & $\mathrm{R} \$ 400,00$ \\
\hline $\begin{array}{l}\text { Single/ } \\
\text { videoclipe }\end{array}$ & $\begin{array}{l}\text { Divulgar o } \\
\text { trabalho, } \\
\text { atingir um } \\
\text { público } \\
\text { amplo, } \\
\text { produzir } \\
\text { conteúdo, } \\
\text { movimentar as } \\
\text { redes sociais }\end{array}$ & $\begin{array}{l}\text { Geraldo/ } \\
\text { Lucas/ } \\
\text { Roger }\end{array}$ & $01 / 06 / 18$ & $\begin{array}{l}\text { Belo } \\
\text { Horizonte }\end{array}$ & $\begin{array}{l}\text { Gravação de imagens em local } \\
\text { ainda a definir }\end{array}$ & $\mathrm{R} \$ 200,00$ \\
\hline
\end{tabular}

Fonte: Elaborado pelo autor (2017) 


\section{pontěditora}

\section{REFERÊNCIAS}

BARON, Robert A.; SHANE, Scott A. Empreendedorismo: uma visão do processo. São Paulo: Thomson Learning, 2007.

CERTO, Samuel C.; PETER, J. P. Administração estratégica. 2. ed. São Paulo: Pearson Education do Brasil, 2005.

CHIAVENATO, Idalberto. Introdução à teoria geral da administração: uma visão abrangente da moderna administração das organizações. 7. ed. Rio de Janeiro: Elsevier, 2003.

CHIAVENATO, Idalberto; MATOS, Francisco Gomes. Visão e ação estratégica: os caminhos da competitividade. 3. ed. Barueri: Manole, 2009.

DOLABELA, Fernando. O segredo de Luísa: uma ideia, uma paixão e um plano de negócios: como nasce o empreendedor e se cria uma empresa. São Paulo: Cultura, 1999.

DORNELAS, José Carlos A. Empreendedorismo: transformando ideias em negócios. Rio de Janeiro: Campus, 2012.

GIL, Antônio Carlos. Como elaborar projetos de pesquisa. 4. ed. São Paulo: Atlas, 2008 .

HAMEL, Gary; PRAHALAD, C. K. Competindo para o futuro. 18. ed. Rio de Janeiro: Elsevier, 1995.

HITT, Michael A.; IRELAND, R. Duane; HOSKISSON, Robert E. Administração Estratégica. 2. ed. São Paulo: Cengage Learning, 2008.

IFPI. FEDERAÇÃO INTERNACIONAL DA INDÚSTRIA FONOGRÁFICA. Global music report. 2016. Disponível em: <http://www.ifpi.org/news/IFPI-GLOBALMUSIC-REPORT-2016/>. Acesso em: 29 abr. 2017.

KOTLER, Philip. ARMSTRONG, Gary. Princípios do Marketing. $9^{\circ}$ Edição. São Paulo: Pearson Prentice Hall, 1998.

KOTLER, Philip. KELLER, Kevin Lane. Administração de marketing. 12. ed. São Paulo: Pearson Prentice Hall, 2006.

KUSEK'S, Dave. Music Business Strategies. Cowboys Ventures, 2014. Disponível em: <http://newartistmodel.com/music-business-strategies/>. Acesso em: 04 maio 2017.

KUSEK, David; LEONHARD, Gerd. The future of music: manifesto for the digital music revolution. Boston: Berklee Press, 2005. 


\section{pontěditora}

LA OTRA. Sua carreira em suas mãos: como se adaptar ao novo cenário musical. 2017. Disponível em: <http://agencialaotra.com/2017/2017/05/02/sua-carreira-em-suasmaos-como-se-adaptar-ao-novo-cenario-musical/>. Acesso em: 03 maio 2017.

LEVESQUE, Paul. Planejar para o sucesso. São Carlos: Futura, 1999.

MARCONI, Marina de Andrade; LAKATOS, Eva Maria. Fundamentos de metodologia científica. 8. ed. São Paulo: Atlas, 2017.

MINTZBERG, Henry et al. O processo da estratégia: conceitos, contextos e casos selecionados. 4. ed. Porto Alegre: Bookman, 2006.

ROCHA, Águida Garreth Ferraz. Planejamento e gestão estratégica. São Paulo: Pearson Education do Brasil, 2012.

SALAZAR, Leonardo. Música LTDA.: o negócio da música para empreendedores. 2. ed. Recife: Sebrae, 2015.

SEBRAE. SERVIÇO BRASILEIRO DE APOIO ÀS MICRO E PEQUENAS EMPRESAS. Como montar e gerir uma empresa. 2017. Disponível em: <http://www.sebrae.com.br/sites/PortalSebrae/tipoconteudo/empreendedorismo?codTe $\mathrm{ma}=2>$. Acesso em: 25 jul. 2017.

VASCONCELOS, Paulo de; PAGNONCELLI, Dernizo. Construindo estratégias para vencer: um método prático objetivo e testado para o sucesso da sua empresa. Rio de Janeiro: Elsevier, 2001.

VERGARA Sylvia Constant. Projetos e relatórios de pesquisa de administração. 3. ed. São Paulo: Atlas, 2007.

VICENTE, Eduardo. Da vitrola ao Ipod: uma história da indústria fonográfica no Brasil. São Paulo: Alameda, 2014.

O trabalho $\mathrm{e}^{3}$ - Revista de Economia, Empresas e Empreendedores na CPLP está licenciado com uma Licença Creative Commons - Atribuição-NãoComercial-Compartilha Igual 4.0 Internacional. 


\section{Serviço pós-venda e fidelização de clientes: estudo de caso numa Farmácia Magistral}

Post-sales service and customer loyalty: case study in a Mastercard Pharmacy

Sayure Brito ${ }^{1}$

${ }^{1}$ E-mail: $\underline{\text { sayurebrito@gmail.com }}$

\begin{abstract}
Resumo: No mercado atual, o serviço de pós-venda pode ser considerado um diferencial competitivo capaz de ajudar as empresas na fidelização dos seus clientes. Diante do grande número de farmácias de manipulação existentes, as farmácias magistrais buscam a cada dia um diferencial competitivo para a retenção de clientes, já que, somente, oferecer medicamentos com valores acessíveis ou produtos de qualidade não contribui mais para atrair novos clientes ou manter os já existentes. O intuito deste trabalho foi avaliar como o serviço de pós-venda pode contribuir na fidelização e retenção de clientes de uma farmácia de manipulação, compreendendo a sua utilização como ferramenta de apoio aos negócios. Para a mensuração dos resultados, utilizou-se a abordagem quantitativa por meio da pesquisa descritiva e estudo de caso. Para a coleta de dados, foi utilizado um questionário estruturado aplicado aos clientes da organização. Os resultados apresentados demonstraram que o consumidor atual valoriza e tende a preferir as organizações que utilizam serviços de pós-venda.
\end{abstract}

Palavras-chave: Pós-venda; Marketing de Relacionamento; Fidelização.

\begin{abstract}
In the current market, the after-sales service can be considered a competitive differential capable of helping companies in the loyalty of their customers. Faced with the large number of existing pharmacies, magistrate pharmacies are seeking a competitive differential for customer retention, since only offering affordable medicines or quality products no longer contributes to attracting new clients or maintaining the existing ones. The purpose of this study was to evaluate how the aftersales service can contribute to the loyalty and retention of customers of a pharmacy of manipulation, including its use as a tool to support business. To measure the results, the quantitative approach was used, through descriptive research and case study. For the data collection, a structured questionnaire was used, applied to the clients of the organization. The results presented demonstrate that the current consumer values and tends to prefer organizations that use after-sales services
\end{abstract}

Keywords: After-sales; Relationship Marketing; Loyalty. 


\section{pontěditora}

\section{Introdução}

No mercado atual percebe-se que a cada dia as organizações estão em busca de aprimoramento das suas atividades. Isso deve-se ao mercado consumidor, que vem demonstrando, cada vez mais, um elevado grau de exigência, requerendo das empresas, muito esforço para se manterem ativas no mercado. "Muitas empresas ainda planeiam seus produtos sem o input do consumidor, apenas para encontrá-los, depois, rejeitados pelo mercado. Esquecem os consumidores após a venda, para perdê-los, depois, aos concorrentes" (KOTLER, 1998, p. 27).

No meio a tanta concorrência, as organizações devem recorrer a estratégias para fidelizar os seus clientes. A rivalidade entre as empresas está cada dia mais acirrada. $\mathrm{O}$ consumidor, por sua vez, apresenta-se mais informado sobre as suas escolhas, não sendo considerado apenas a preferência de um produto/serviço pelo seu preço ou qualidade, mas também, a influência da organização em contribuir para sua escolha.

Assim como qualquer outro ramo de atividade, as farmácias de manipulação também sofrem a pressão dos seus concorrentes. O crescimento tecnológico proporcionou à indústria farmacêutica a disponibilização de medicamentos com valores mais acessíveis ao consumidor, fazendo com que as farmácias de manipulação buscassem outros meios de continuar as suas atividades, não dependendo somente da manipulação de fórmulas farmacêuticas, que até então, antes deste crescimento económico, era o meio que mais sustentava o ramo de suas atividades. Com isso, observou-se que somente a venda de medicamentos com valores mais acessíveis, ou produtos de qualidade, já não é suficiente para resistirem ao mercado. Diante da situação apresentada, chegou-se ao seguinte problema de pesquisa: a utilização da ferramenta pós-venda, poderia ser um meio de fidelizar o cliente?

Portanto, as empresas devem buscar a fidelização dos seus clientes, utilizando das ferramentas do marketing, respostas para os problemas que são cada vez mais constantes, analisando a real necessidade de desenvolver uma atividade em prol do desenvolvimento de relações com os clientes. A empresa, foco da pesquisa, consiste numa farmácia mineira, localizada na região centro-sul de Belo Horizonte, com atuação 


\section{pontěditora}

no ramo de farmácia de manipulação. Fundada em 2000, está no mercado há mais de 16 anos. Composta por 11 funcionários, além dos dois sócios que também trabalham na empresa, está estruturada da seguinte forma: cinco atendentes, uma farmacêutica e cinco colaboradores que atuam no setor de produção. Além da atividade central de manipulação de fórmulas farmacêuticas, ainda oferece uma linha própria de produtos cosméticos.

Por ser uma farmácia de manipulação, a legislação do setor não permite que essas empresas produzam seus produtos de revenda dentro do estabelecimento. Sendo assim, a empresa terceiriza toda a sua linha de produtos. Um dos sócios da empresa, com formação farmacêutica, bioquímica e industrial foi quem desenvolveu a linha de produtos cosméticos. Com foco no portfólio dos seus produtos, a empresa busca, como público-alvo, atender profissionais que atuam na área da estética, tendo em vista que, com este perfil de clientes, consiga expandir com mais facilidade a sua linha de produtos.

Assim, o objetivo geral deste trabalho consiste em analisar a relação do serviço pósvenda com os clientes e identificar se esse serviço, na percepção dos mesmos, contribui para a sua fidelização. Em decorrência do objetivo geral, os objetivos específicos foram: Levantar o perfil e necessidades dos clientes; avaliar o grau de satisfação do cliente em relação a diversos aspetos que envolvem o atendimento recebido; analisar a importância do serviço de pós-venda na perceção do cliente; analisar a vantagem de utilização do serviço pós-venda, como diferencial competitivo e apresentar propostas para a fidelização, se for o caso.

\section{Marketing}

O marketing representa uma das áreas da administração que em meio à economia tão assoladora, cada vez mais vem sendo estudado no mercado atual. Sendo o marketing um processo tão difundido mediante o cenário global, torna-se necessário definir o conceito de marketing a ser utilizado neste trabalho. Na visão de muitos, o marketing resume-se apenas em propaganda, limitando o seu campo de visão a esse pensamento, entendendo que, por meio da divulgação de um produto, serviço ou marca, estimula-se o interesse

$\mathrm{e}^{3}$ - Revista de Economia, Empresas e Empreendedores na CPLP | Volume 4 | Número 1 


\section{pontěditora}

de compra do consumidor. Porém, o marketing vai muito além disso.

Pode-se entender que o marketing consiste num processo empregado pelas organizações como meio de fazer negócios. De forma mais sucinta e objetiva, o marketing envolve clientes e a organização, sendo encarado como uma filosofia em que todos os membros da organização entendem o seu real conceito, como meio de alcançar os objetivos da empresa.

Ou seja, pode-se entender que o marketing significa um processo de planeamento e execução de funções disponíveis às empresas, a fim de criar trocas que satisfaçam metas individuais e organizacionais (CHURCHILL JR; PETER, 2012). Ainda segundo Churchill Jr. e Peter (2012), a essência do marketing está em desenvolver trocas voluntárias entre clientes e empresa, de modo que essas transações proporcionem benefícios para ambos.

O marketing envolve um conjunto diversificado de atividades direcionadas a ampla gama de bens, serviços e ideias. Tais atividades envolvem o desenvolvimento, a determinação de preço, a promoção e a distribuição de bens e serviços que atendam os desejos de consumidores e usuários industriais. Portanto, as atividades de marketing são importantíssimas tanto para as empresas individualmente como para a economia como um todo. (FUTRELL, 2003, p. 33)

Segundo Kotler (1998), o marketing constitui em um processo gerencial, pelos quais, indivíduos ou grupos obtêm o que necessitam por meio da criação, oferta ou troca de produtos de valor com os outros.

Para um melhor entendimento do conceito apresentado pelo autor, apresentam-se a seguir os quatro pilares que, segundo Kotler (1998), fundamenta o conceito de marketing:

- Mercado alvo: Nenhuma empresa pode operar em todos os mercados e satisfazer a todas às necessidades. Nem pode fazer um bom trabalho dentro de um mercado. As empresas trabalham melhor quando definem cuidadosamente o seu mercado alvo e preparam um programa de marketing sob medida.

$\mathrm{e}^{3}$ - Revista de Economia, Empresas e Empreendedores na CPLP | Volume 4 | Número 1 


\section{pontěditora}

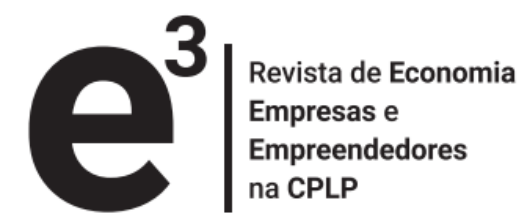

- Necessidades dos consumidores: Uma empresa pode definir o seu mercado alvo, mas falhar em conhecer plenamente as necessidades dos consumidores.

- Marketing integrado: Quando todos os departamentos da empresa trabalham em conjunto para tender aos interesses dos consumidores, o resultado é marketing integrado. Infelizmente, nem todos os funcionários são treinados e motivados a trabalhar para o consumidor.

- Rentabilidade: O propósito final do conceito de marketing é ajudar as organizações a atingir as suas metas. Nas organizações que visam o lucro, a chave não é atingir o lucro como tal, mas como subproduto de um bom trabalho. Uma empresa que melhor satisfaça as necessidades dos consumidores ganha mais dinheiro do que as suas concorrentes.

A partir destes levantamentos, pode-se compreender melhor o entendimento sobre o marketing e o seu papel no contexto das empresas, sendo considerado essencial em prol dos negócios oferecidos por uma organização. Nesse sentido, a próxima secção discute e importância do marketing de relacionamento para os resultados organizacionais.

\subsection{Marketing de relacionamento}

Nas últimas décadas, percebe-se que a visão das empresas, que encaram o marketing tradicional como meio de atrair novos clientes, vem ganhando uma nova visão. Genericamente, o marketing tradicional baseia-se na atração de novos clientes, desligando-se da retenção dos clientes já existentes (KOTLER; ARMSTRONG, 2015). Futrell (2003) diz que a ênfase do marketing de relacionamento está em direcionar o foco das vendas no cliente de hoje para a criação dos clientes de amanhã, fazendo com que as empresas pensem no cliente a longo prazo e não a curto prazo.

A organização que faz uso do marketing de relacionamento não está buscando uma simples venda ou transação. Ela se concentra num grande cliente para o qual gostaria de vender agora e no futuro. A empresa quer demonstrar ao cliente que ela dispõe dos recursos para atender as necessidades dele da melhor forma possivel, especialmente se puder ser criado um relacionamento comprometido. (FRUTELL, 2003, p. 42)

Por conta do avanço tecnológico, o aumento da competitividade expandiu-se ainda mais, levando as empresas a encarar um novo mercado. Com o avanço da tecnologia, não só 


\section{pontěditora}

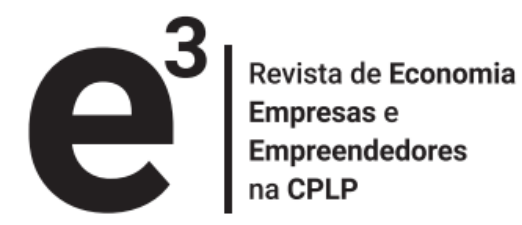

as empresas puderam ganhar forças e serem mais competitivas, mas também o cliente, que por sua vez, se tornou mais informando, ficando mais exigente em relação à escolha de compra.

Com isso, as empresas começaram a mudar as suas atitudes em relação à retenção de clientes, desencadeando o marketing de relacionamento. Kotler e Armstrong (2015) afirmam que o marketing de relacionamento busca criar, manter e aprimorar um relacionamento sólido com os clientes.

"A gestão do relacionamento com o cliente consiste em todo o processo de construir e manter relacionamentos lucrativos com os clientes entregando-lhes valor superior e satisfação" (KOTLER; ARMSTRONG, 2015, p. 12).

Para o marketing de relacionamento com o cliente, o principal propulsor da lucratividade da empresa é o valor agregado da sua base de clientes. Empresas vencedoras são as que mais adquirem, mantêm e desenvolvem clientes. Essas empresas aumentam o valor de sua base de clientes destacando-se na redução da taxa de perda de clientes, no aumento do período de relacionamento com o cliente, na elevação do potencial de receita e lucro de seus clientes, na transformação de clientes de baixo lucro em clientes mais lucrativos (ou na eliminação daqueles) e na concentração em clientes de alto valor. (KOTLER, 2005, p. 35)

O marketing de relacionamento apresenta-se como uma nova postura de interação entre a empresa e o cliente, gerando vínculos económicos e sociais entre as partes. " $\mathrm{O}$ marketing de relacionamento é baseado na premissa de que os clientes importantes precisam receber atenção contínua" (KOTLER, 1998, p. 619).

Contudo, as empresas estão percebendo que manter vínculos com os seus clientes significa um diferencial no sentido de manterem-se mais competitivas no mercado. $\mathrm{O}$ relacionamento com o cliente desencadeia uma corrente de valor ao cliente, fundamentando um relacionamento de longo prazo. "As empresas de hoje constroem relacionamentos mais profundos, diretos e duradouros com os clientes mais cuidadosamente selecionados" (KOTLER; ARMSTRONG, 2015, p. 16). Frutell (2003) menciona os três níveis do marketing de relacionamento com o cliente, fundamentando assim, este conceito.

- Vendas da transação única: Os clientes compram e não voltam a ser contactados. 


\section{pontěditora}

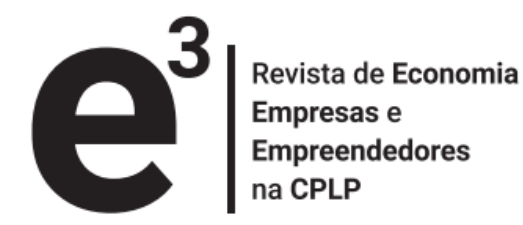

- Vendas de relacionamento: A empresa entra em contacto com os clientes após a compra para verificar se eles estão satisfeitos e se tem necessidades futuras.

- Parceria: A empresa trabalha continuamente no sentido de melhorar as operações, as vendas e o lucro dos seus clientes.

Nesse sentido, Futrell (2003) menciona que o marketing de relacionamento deve concentra-se na transação, em fazer a venda e acompanhar o serviço de pós-venda junto ao cliente.

A empresa deve relacionar-se ao cliente para verificar a satisfação com a compra.

Na próxima secção será abordado o tema das estratégias ligadas aos serviços pós-venda.

\subsection{Serviços de pós-venda}

O surgimento do serviço pós-venda relaciona-se com algumas particularidades da teoria do marketing, pois a prática de procurar manter o cliente fiel a uma empresa baseia-se no relacionamento com o cliente.

Atualmente, os clientes não procuram empresas que prestam o melhor serviço ou vendem os melhores produtos, para além disso, buscam empresas que lhes proporcionam junto ao serviço ou produto, a satisfação de si mesmo em comprar algo naquele ambiente escolhido.

"De nada adianta apenas vender e vender. É preciso mais do que isso para conquistar o cliente, impressioná-lo e torna-lo fiel" (CHIAVENATO, 2014, p. 241). Portanto, o objetivo do pós-venda consiste em gerar satisfação e fidelização ao cliente. Um cliente satisfeito poderá gerar novos clientes a uma organização, por meio de comentários positivos entre amigos e familiares.

À medida que a organização transmite confiança ao cliente, o mesmo se sente mais disposto a comprar novos produtos pela empresa. Sendo assim, o esforço na retenção de clientes, permite à redução de despesas, em que a mesma poderá reduzir os custos com propagandas e promoções de venda, buscando atrair novos clientes ou manter os clientes já existentes. 


\section{pontěditora}

A empresa precisa dedicar-se ao relacionamento posterior à venda. Com isso, manterá o cliente satisfeito, garantindo o seu retorno para uma próxima compra e estimulando a aquisição de produtos da mesma marca (BARRETO; CRESCITELLI, 2013).

Para Chiavenato (2014), o serviço de pós-venda abrange todas as atividades posteriores à venda, considerando parte imprescindível do processo de venda. Ou seja, o relacionamento pós-venda gera valor ao cliente, fazendo com que o mesmo crie uma corrente de compromisso com a empresa, gerando uma vida inteira de compras.

Da mesma maneira, como toda e qualquer empresa faz um seguimento (Follow-up) de suas compras corporativas, o consumidor costuma fazer o mesmo. $O$ agendamento da entrega daquilo que foi vendido, os serviços de assistência técnica, a resolução de possiveis problemas que independem do cliente e escapam ao seu controle, e a certeza de que as expectativas do cliente estão sendo plenamente satisfeitas são aspectos importantes no pós-venda, que influenciam poderosamente os hábitos e as decisões futuras de compra por parte do consumidor. (CHIAVENATO, 2014, p. 244)

O serviço de pós-venda pode proporcionar às empresas uma maior competitividade no mercado, a partir do momento que se procura conhecer melhor o seu cliente, como meio de mantê-lo na sua carteira de consumidor. As empresas, ao mesmo tempo, geram satisfação ao cliente, dando-lhe suporte ao serviço de pós compra, superando assim as suas expetativas e contribuindo com este feedback sobre a venda, estratégias para as empresas definirem com maior prontidão, o seu segmento de clientes, conhecendo-os individualmente.

Para Chiavenato (2014, p. 244), “A pós-venda deve ser encarada como um aspecto tão importante quanto à própria venda, da mesma forma como a eficiência deve ser sempre acompanhada pela eficácia".

Tendo em vista a necessidade do desenvolvimento de estratégias que aumentem a eficiência e eficácia, conforme defendido por Chiavenato (2014), na secção seguinte será tratado o tema da satisfação do cliente como estratégia para sua retenção. 


\section{pontěditora}

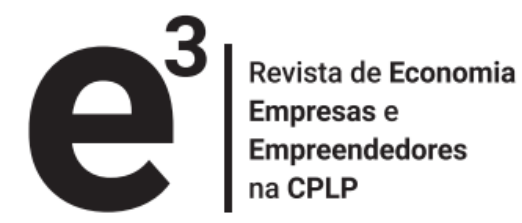

\subsection{Satisfação dos clientes}

Os desafios das organizações não estão ligados somente a planear, dirigir e controlar de maneira eficiente e eficaz os negócios da empresa. As empresas estão procurando dar uma maior atenção aos seus clientes, preocupando-se em satisfazer as suas necessidades e desejos.

Manter os clientes fiéis a uma empresa, nos dias atuais, tem sido uma missão cada vez mais difícil, pois os clientes apresentam-se cada vez mais exigentes, e com a concorrência acirrada, leva a sua retenção aquelas que melhor os satisfazer. Diante deste cenário, pode-se compreender que a existência das empresas gira em torno da satisfação do consumidor.

Todo o esforço mercadológico gira em torno da satisfação do consumidor. A pesquisa de marketing, a concepção e o desenvolvimento de produtos, com a sua definição de preço, distribuição e promoção, visam essencialmente à satisfação de necessidades ou desejos dos compradores, auferindo, como consequência da troca, o lucro almejado para a sustentabilidade do negócio. (SAMARA; MORSCH, 2005, p. 204)

"A satisfação do comprador após a realização da compra depende do desempenho da oferta em relação às suas expectativas" (KOTLER; KELLER, 2006, p. 142). O cliente agrega valor à sua decisão de compra, com base no que recebe da empresa. Em função disso, Kotler e Keller (2006) levam a compreender que a chance do cliente retornar a fazer outra compra na empresa dependerá se a empresa alcançou ou não essa expetativa de valor desse mesmo cliente.

A satisfação do cliente consiste na sensação de agrado que ele sente ao adquirir um produto/serviço. "Uma empresa deve proporcionar aos clientes uma satisfação maior que os custos que ela lhes solicita para adquirir o produto (ou serviço)" (SAMARA; MORSCH, 2005, p. 203).

Os clientes criam expectativas a partir do momento que sentem necessidades ou problemas que podem ser resolvidos por meio de um produto ou serviço. Com isso, suas expetativas são resultados que vão além do produto ou serviço tomados isoladamente. Ao se obter uma expetativa não esperada, isso, gera satisfação ao cliente.

Futrell (2003) ressalta que a satisfação do cliente está ligada às expetativas atendidas.

$\mathrm{e}^{3}$ - Revista de Economia, Empresas e Empreendedores na CPLP | Volume 4 | Número 1 


\section{pontěditora}

Refere-se também a sentimentos relacionados à compra. "A satisfação percebida com a compra é a sensação do cliente em relação a qualquer diferença entre o que é esperado e a experiência real da compra" (FUTRELL, 2003, p. 344).

Oferecer produtos e serviços que satisfaçam as necessidades dos clientes, exige aprofundamento das empresas em conhecer o cliente, tendo conhecimento sobre as expetativas que eles esperam. As empresas devem priorizar as expetativas do cliente, identificando as mudanças e se adequando para atendê-las.

A empresa deve avaliar a satisfação dos clientes com regularidade, pois a chave para reter clientes, está em satisfazê-los (KOTLER; KELLER, 2006). Quando o cliente se sente satisfeito com uma organização, ela pode esperar deste cliente um relacionamento duradouro, de longo prazo.

\subsection{Fidelização e retenção do cliente}

Atualmente, os clientes têm se apresentado mais difíceis de agradar, sendo mais inteligentes em relação aos diversos factores decisivos para fazer a escolha de compra e, além disso, estão mais conscientes em relação aos preços, perdoam menos e sofrem maior pressão da concorrência com ofertas iguais ou superiores. Com isso, o desafio em reter os clientes de hoje não consiste em deixá-los satisfeitos, tendo em vista que a concorrência pode fazer isso, o desafio consiste em conquistar clientes fiéis (KOTLER; KELLER, 2006).

Diante deste cenário, algumas organizações buscam métodos de atrair e reter clientes potenciais, a fim de criar vínculos de longo prazo, e para se criar um relacionamento duradouro, deve-se encontrar artifícios de fidelização e retenção deste cliente.

A fidelidade é um dos objetivos principais da ação do marketing: a intenção não é contar apenas com clientes eventuais, que fazem algumas compras vez ou outra; mas cativá-los de modo que sempre voltem e procurem manter-se vinculados à marca. (GARCIA, 2015, p. 31)

Barreto e Crescitelli (2013) afirmam que a fidelização dos clientes significa um dos principais objetivos do marketing de relacionamento, em que se percebe a importância

$\mathrm{e}^{3}$ - Revista de Economia, Empresas e Empreendedores na CPLP | Volume 4 | Número 1 
de entender o que leva o cliente a se tornar fiel, bem como a identificar a fidelidade do cliente depois de conquistada. "A identificação da fidelidade ou não de um cliente é um dos principais elementos de avaliação dos resultados de uma ação de relacionamento" (BARRETO; CRESCITELLI, 2013, p. 71).

Pode-se definir a fidelidade como a repetição de compra. Porém, isso não é o bastante para definição do tema, já que nem sempre o facto de um cliente repetir uma compra significa que está fidelizado. A fidelização vai muito além disso.

Manter clientes fiéis costuma sair mais barato que buscar um novo cliente a todo o tempo. Além disso, clientes fidelizados costumam gerar um importante retorno financeiro para as empresas. Diante disso, toda a instituição deve acompanhar o nível de fidelidade dos seus clientes (GARCIA, 2015).

Atrair e reter clientes pode ser uma tarefa difícil. Com frequência, os clientes têm a sua disposição uma grande variedade de produtos e serviços para escolher. $O$ cliente compra da empresa que lhe oferece o mais alto valor percebido pelo cliente - a avaliação que o cliente faz da diferença entre todos os benefícios e todos os custos de uma oferta ao mercado em relação às ofertas concorrentes. (KOTLER; ARMSTRONG, 2015, p. 13)

Muitas vezes, as empresas confundem a satisfação do cliente como sinónimo de fidelização. Nem sempre uma acarreta a outra. Pode ocorrer um consumidor comprar algo numa empresa, não por se sentir fidelizado, mas por conveniência. Com isso, Garcia (2015) diz que a fidelidade de um cliente não pode ter como base apenas a satisfação do mesmo.

Torna-se necessário encontrar meios de identificar se o cliente se sente fidelizado ou não com o serviço ou produto disponibilizado pela empresa. "Existem clientes satisfeitos que não são fiéis, mas existem também clientes insatisfeitos que o são" (GARCIA, 2015, p. 31).

Assim, observa-se que muitos clientes compram de empresas por que se sentem satisfeitos com a prestação do serviço, ou do produto. Isso não leva a crer que o cliente seja fiel àquela empresa. Ele pode sentir-se satisfeito em comprar determinada marca, 


\section{pontěditora}

mas sofre influência de outras marcas, fazendo com que utilize outros produtos/serviços. Por conta disso, Garcia (2015, p. 32) leva a compreender que "esses fatores mostram que é preciso medir a fidelidade desvinculando-a da satisfação".

Kotler e Armstrong (2015) afirmam que uma boa gestão de relacionamento com o cliente, gera o encantamento do mesmo. Em função disso, torna-se essencial que as empresas procurem meios de fidelização do cliente. $\mathrm{O}$ cliente cativado pode permanecer fiel, levando a outros consumidores, ideias favoráveis sobre a empresa e seus produtos.

Estudos mostram grandes diferenças entre a fidelidade de clientes que estão menos satisfeitos, relativamente satisfeitos e completamente satisfeitos. Mesmo uma pequena queda da plena satisfação pode criar uma enorme queda na "fidelidade". Assim, o objetivo da gestão de relacionamento com o cliente não é apenas gerar a sua satisfação, mas também o seu encantamento. (KOTLER; ARMOSTRONG, 2015, p. 20)

Portanto, as empresas percebem que perder um cliente representa mais do que perder uma única venda, significa perder o valor de todas as compras que um cliente faria ao longo de um relacionamento de fidelidade (KOTLER; ARMSTRONG, 2015).

\section{Metodologia}

Pode-se definir pesquisa como o "procedimento racional e sistemático que tem como objetivo proporcionar respostas aos problemas que são propostos" (GIL, 2009, p. 17). Para Vergara (2008), os tipos de pesquisa podem ser definidos por dois critérios básicos: quanto aos fins e quanto aos meios.

Sendo assim, quanto aos fins foi realizada uma pesquisa descritiva, sendo esta a técnica de pesquisa escolhida que acreditou-se ser a melhor que apresentaria os dados a serem averiguados, permitindo analisar o serviço de pós-venda como ferramenta de fidelização dos clientes da farmácia de manipulação.

Os estudos descritivos, também chamados pesquisas Ad Hoc, como diz o próprio nome, procuram descrever situações de mercado a partir de dados primários, obtidos originalmente por meio de entrevistas pessoais ou discussões em grupo, relacionando e confirmando as hipóteses levantadas na definição do problema de pesquisa. (SAMARA; BARROS, 2006, p.50)

A pesquisa descritiva objetiva descreve as características de determinada população ou 


\section{pontěditora}

fenómeno, ou estabelecimento de relações entre variáveis (KAUARK; MANHÃES; MEDEIROS, 2010). As características que melhor a define consistem na adoção de técnicas padronizadas de coletas de dados tais como a utilização de questionários e observação sistémica (GIL, 2009).

Segundo Gil (2009), a pesquisa descritiva pode ir além da simples identificação da existência de relações entre variáveis, pretendendo determinar a natureza dessa relação. Vergara (2000, p. 47) "argumenta que a pesquisa descritiva expõe as características de determinada população ou fenômeno, estabelece correlações entre variáveis e define sua natureza”.

Quanto aos meios, utilizou-se o estudo de caso com abordagem quantitativa. Para Gil (2009), o estudo de caso consiste no estudo profundo e árduo de um ou poucos objetivos, de forma que permita o amplo e detalhado conhecimento. Gil (2009) afirma que os propósitos do estudo de caso não estão em propor conhecimento preciso das características de uma população, mas sobretudo, em proporcionar uma visão global do problema ou identificar possíveis factores que influenciam ou são por ele influenciados.

O questionário estruturado foi o instrumento adotado para a coleta de dados, buscando analisar a perceção dos participantes sobre a importância do serviço de pós-venda no processo de fidelização dos clientes, avaliando se a implantação de serviço pós-venda contribuirá em prol da fidelização do cliente.

A amostra do estudo contou com a participação de 58 clientes da empresa que preencheram o questionário semiestruturado, composto por 15 questões, como instrumento adotado para a coleta de dados. "A amostragem é uma parcela conveniente selecionada do universo (população); é um subconjunto do universo" (MARCONI; LAKATOS, 2005, p. 165). Segundo Marconi e Lakatos (2002), "amostragem" não probabilística tem como característica principal não fazer uso de formas aleatórias de seleção, tendo sido esse tipo o adotado neste estudo.

Segundo Marconi e Lakatos (2005), após a coleta dos dados o passo seguinte consiste em elaborar e classificar estes elementos de forma sistemática. Tendo em vista a 


\section{pontěditora}

abordagem quantitativa, os dados foram analisados estatisticamente, sendo apresentados por meio de gráficos.

\section{Apresentação e discussão dos resultados}

Este trabalho utilizou a técnica de pesquisa do tipo descritiva, com o intuito de identificar por meio da análise das características da população em estudo, se o serviço de pós-venda pode ser um meio de fidelização dos clientes da empresa pesquisada. Estão apresentados a seguir os dados mais relevantes da pesquisa. Buscou-se analisar o diferencial competitivo que a empresa pode alcançar por meio de clientes fidelizados.

Referindo-se ao perfil sócio económico dos clientes da empresa, a pesquisa apresentou que o perfil predominante consiste em pessoas do sexo feminino, correspondente a mais de $90 \%$ dos pesquisados. Relativo à faixa etária, $88 \%$ dos entrevistados possuem idade entre 21 e 40 anos. A pesquisa demonstrou que 43,1\% dos entrevistados possuem renda familiar acima de $\mathrm{R} \$ 5.000,00$, indicando que os clientes da farmácia possuem um poder aquisitivo de nível mais elevado.

A seguir, apresenta-se os resultados considerados mais relevantes para a análise dos dados coletados e esclarecimento do problema de pesquisa do estudo.

O Gráfico 1 apresenta a importância, na perceção do entrevistado, do serviço de pósvenda no processo de fidelização do cliente.

Gráfico 1 - Importância do serviço de pós-venda para a fidelização dos clientes

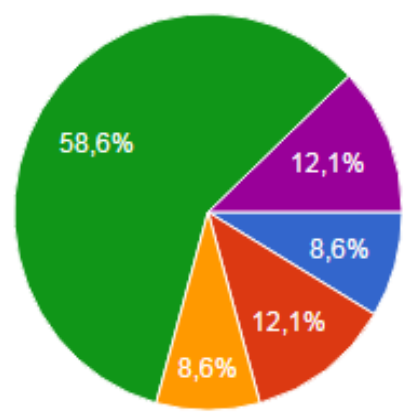

Concordo totalmente

Concordo parcialmente

Não concordo e não discordo

Discordo totalmente

Discordo parcialmente

Fonte: Dados da pesquisa (2017).

$\mathrm{e}^{3}$ - Revista de Economia, Empresas e Empreendedores na CPLP | Volume 4 | Número 1 


\section{pontěditora}

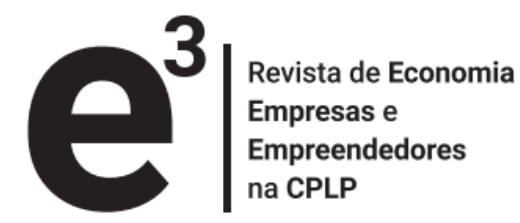

Observa-se no Gráfico 1 que 70,7\% dos clientes da empresa discordam totalmente ou parcialmente, que a utilização dos serviços de pós-venda tem pouca relevância em relação a sua fidelização. Com base neste resultado, pode-se concluir que grande parte dos clientes entrevistados consideram a ferramenta pós-venda um meio de fidelização importante. Sendo assim, nota-se que os clientes atuais tendem a priorizar as empresas que lhe dão atenção após o momento da compra, reforçando o entendimento de Kotler e Armstrong (2015) que aponta que a gestão do relacionamento com o cliente baseia-se em todo o processo de construir e manter relacionamentos lucrativos, em prol de lhe dispor valor superior e satisfação.

O Gráfico 2 exibe a perceção do entrevistado, em relação à sua opinião e à sua escolha em dar preferências a um bom atendimento ou ofertas e promoções da concorrência.

Gráfico 2 - Preferências dos entrevistados em relação à importância do atendimento recebido VS ofertas e promoções da concorrência.

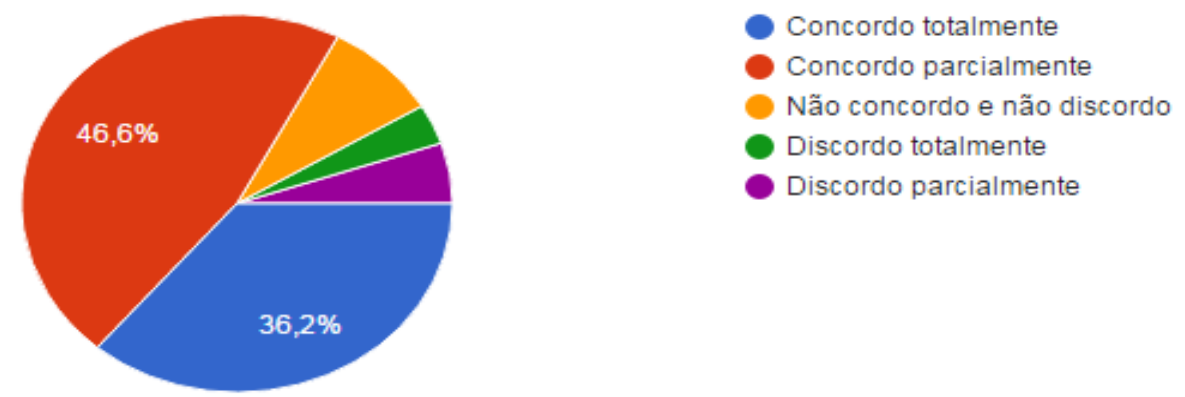

Fonte: Dados da pesquisa (2017).

Observa-se pelo Gráfico 2 que mais da metade dos clientes consideram que o bom atendimento supera o esforço da concorrência no que diz respeito às ofertas e promoções, tendo sido apontado por $82,8 \%$ dos pesquisados, concordando totalmente ou parcialmente com essa afirmação. Esse dado torna-se de grande relevância para a empresa em estudo, pois demostra a importância em se oferecer um bom atendimento aos seus clientes, corroborando a sugestão de Kotler e Armstrong (2015) quando afirmam que atrair e reter clientes não representa uma tarefa fácil para as organizações. 


\section{pontěditora}

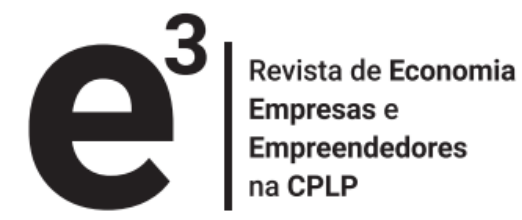

Com grande frequência, os clientes vêem ao seu redor uma grande variedade de produtos e serviços à sua escolha, onde a avaliação que o cliente faz da diferença entre os benefícios e todos os custos das ofertas oferecidas, em relação à oferta da concorrência, leva a sua escolha de compra à empresa que lhe dispor o mais alto valor percebido. Os autores ainda destacam que, por mais importante que seja um bom atendimento para atrair os clientes, considera-se ponderoso que as empresas tenham consciência que, somente isto, não é suficiente para a retenção do consumidor. Conforme Kotlere Armstrong (2015), as empresas devem procurar entregar maior valor ao cliente, fazendo com que o mesmo tenha encantamento pelo serviço prestado.

O Gráfico 3 apresenta a opinião dos entrevistados em relação à sua visão a respeito do serviço de pós-venda em termos de valor agregado ao produto.

Gráfico 3 - Serviço de pós-venda, capaz de agregar valor ao produto adquirido.

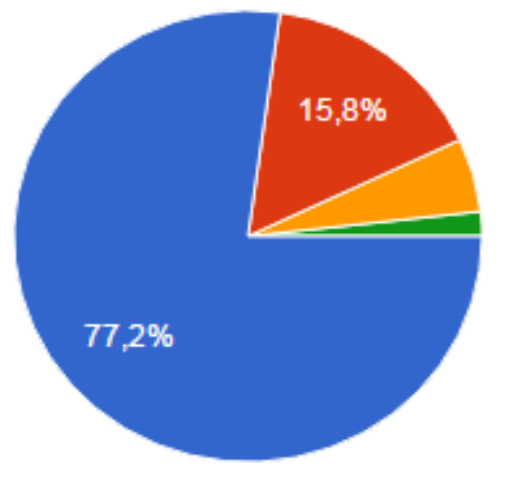

Concordo totalmente

Concordo parcialmente

Não concordo e não discordo

Discordo totalmente

Fonte: Dados da pesquisa (2017).

Percebe-se, na análise do Gráfico 3, que 93,0\% dos clientes concordam total ou parcialmente que o serviço de pós-venda pode agregar valor ao produto adquirido. Dessa maneira, pode-se anunciar que os clientes consideram um valor agregado às empresas que se recordam deles após o momento da compra. Na opinião de Futrell (2003), existem 3 níveis do marketing de relacionamento com o cliente, sendo estes: vendas da transação única, vendas de relacionamento e parceria; ressaltando que nas vendas de relacionamento, a empresa deve entrar em contacto com seus clientes após a compra, para averiguar a sua satisfação e se os mesmos possuem necessidades futuras. Sendo assim, o marketing de relacionamento deve concentrar-se em fazer a venda e 


\section{pontěditora}

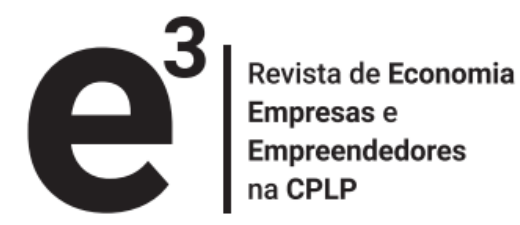

acompanhar o serviço de pós-venda junto ao cliente.

Para a empresa em estudo, que possui uma linha própria de produtos cosméticos, esse dado representa importância de destaque, contribuindo para a melhoria dos seus produtos comercializados. Uma vez que, ao utilizar o serviço de pós-venda junto ao cliente, a empresa pode obter sugestões de aperfeiçoamento para o produto adquirido pelo cliente.

O Gráfico 4 apresenta a sua avaliação do pesquisado sobre o contacto recebido após a realização da compra.

Gráfico 4 - Contato pós-venda após a realização da compra.

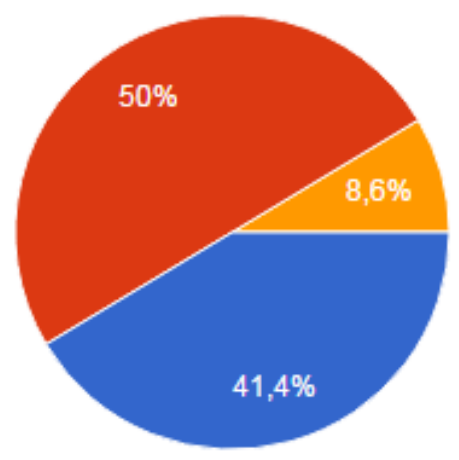

Muito importante

Importante

Pouco importante

Muito pouco importante

Fonte: Dados da pesquisa (2017).

Nota-se no Gráfico 4 que, na perceção do cliente, o contacto após a compra representa um factor importante ou muito importante no processo de fidelização, sendo este considerado por $91,4 \%$ dos respondentes. Reforçando o que já apontou Chiavenato (2014) quando sugeriu que o serviço de pós-venda abrange todas as atividades posteriores à venda, considerando parte imprescindível do processo de venda. Ou seja, o relacionamento pós-venda gera valor ao cliente, fazendo com que o mesmo crie uma corrente de compromisso com a empresa, gerando uma vida inteira de compras. Esse resultado demostra que quase $100 \%$ dos clientes pesquisados entendem a importância em obter o contacto após a realização da compra. Com isso, torna-se essencial que a empresa desenvolva um cronograma de contacto com os clientes ativos, como meio de alcançar a retenção destes.

$\mathrm{e}^{3}$ - Revista de Economia, Empresas e Empreendedores na CPLP | Volume 4 | Número 1 


\section{pontěditora}

O Gráfico 5 buscou avaliar o grau de satisfação dos clientes em relação ao atendimento recebido.

Gráfico 5 - Satisfação em relação ao atendimento recebido.

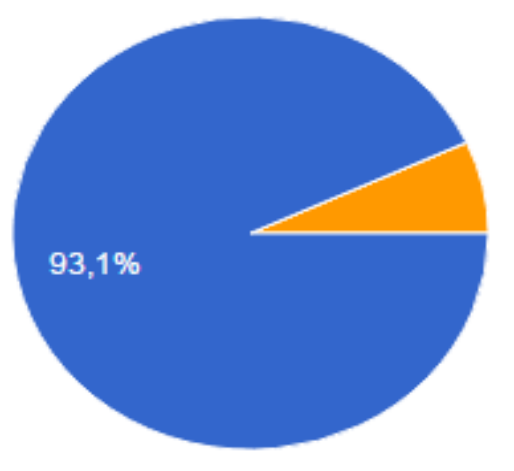

Satisfeito

Insatisfeito

Parcialmente satisfeito

Fonte: Dados da pesquisa (2017).

Observa-se no Gráfico 5 que 93,1\% dos clientes demostram satisfação com o atendimento recebido na empresa pesquisada, estando o restante $(6,9 \%)$ parcialmente satisfeito. Nota-se que, para Kotler e Keller (2006), a satisfação do consumidor após a realização da compra depende da execução da oferta em relação às suas expetativas, ressaltando que o cliente agrega valor na sua decisão de compra, com base no que recebe da empresa. Já Samara e Morsch (2005) declaram que a empresa deve comprometer-se com os clientes buscando proporcionar uma satisfação maior do que os custos que este teve para adquirir o produto/serviço. Contudo, a empresa não pode deixar de basear somente na satisfação do cliente diante desta demonstração. Com isso, nota-se que é preciso mais que um bom atendimento para reter um cliente. Satisfação não é sinónimo de retenção. A satisfação pode ser percebida pelo consumidor em diversos momentos, mas a retenção do cliente vai além de um bom atendimento ao satisfaze-lo.

No Gráfico 6 buscou-se identificar a opinião dos pesquisados relativamente às empresas que possuem serviços de pós-venda, considerando-se aquelas que utilizam essa ferramenta como vantagem competitiva aos negócios, e se estes, dão preferência a empresas que oferecem o serviço pós-venda. 


\section{pontěditora}

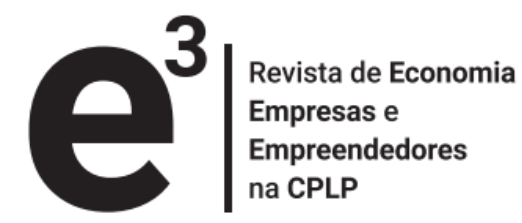

Gráfico 6 - Preferência dos clientes em relação às empresas que utilizam serviços de pós-venda.

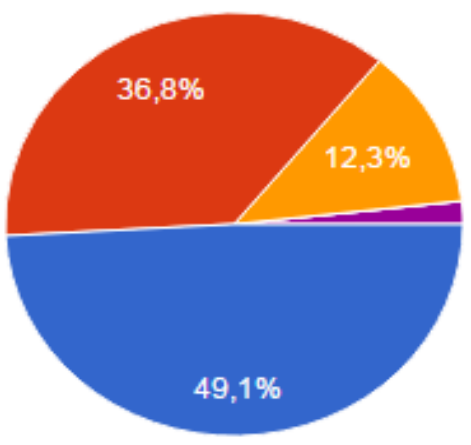

Concordo totalmente

Concordo parcialmente

Não concordo e não descordo

Discordo totalmente

Discordo parcialmente

Fonte: Dados da pesquisa (2017).

Os resultados expressos no Gráfico 6 apontam que 85,9\% dos clientes dão preferência a uma empresa que possui o serviço de pós-venda. Apenas 12,3\% diz-se indiferente a esse quesito e 1,8\% não considera o serviço com uma vantagem competitiva. Esse resultado evidencia que grande parte dos consumidores dão preferência às empresas que utilizam os serviços de pós-venda. Futrell (2003) menciona que o marketing de relacionamento não busca uma simples venda ou transação. As empresas que priorizam essa estratégia, concentram-se em clientes hoje, para garantirem o cliente de amanhã.

Dessa forma, as empresas devem demonstrar aos clientes que dispõem dos recursos para atender as suas necessidades da melhor maneira, principalmente se puder criar um relacionamento comprometido. Assim, os resultados apontam que os clientes enxergam que a ferramenta pós-venda pode ser um diferencial competitivo para as empresas que a utilizem. Ainda que o objetivo das organizações seja desenvolver clientes fiéis, a lealdade dos clientes não se apresenta tão resistente ao ponto de esquecerem o que a concorrência dispõe. Diante disso, o serviço de pós-venda pode ser relevante no sentido de identificar a perceção do cliente em relação à empresa e também à concorrência.

\section{Considerações finais}

O estudo procurou analisar a relação do serviço pós-venda com os clientes e identificar se esse serviço, na percepção dos clientes, contribui para a sua fidelização. Diante dos 


\section{pontěditora}

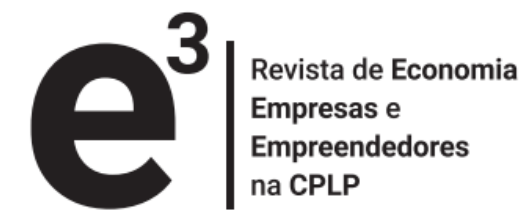

dados analisados, observou-se que os clientes dão preferência às organizações que os distinguem não apenas como consumidores, mas que procuram entender os seus desejos e necessidades, dando importância à sua opinião relativamente aos serviços e ao produto. Isso significa que o serviço de pós-venda representa uma ferramenta muito importante para as empresas, no sentido de dar ao cliente a oportunidade de retornar ofeedback que ele espera e, ao mesmo tempo, faz com que o cliente se sinta parte importante desse processo, levando-o à fidelização.

Em decorrência dos resultados, a pesquisa respondeu a todos os objetivos estabelecidos para o estudo, sendo possível identificar que a empresa possui clientes potenciais que contribuirão para o êxito futuro da organização, já que estes apresentaram-se satisfeitos com os serviços recebidos e com os produtos adquiridos. Além de certificar que os consumidores atuais dão preferência a empresas que utilizam estratégias baseadas no relacionamento com o cliente, percebendo essa estratégia como uma vantagem competitiva das organizações.

Desse modo, evidencia-se que os resultados manifestados reconhecem que os clientes priorizam as empresas que estabelecem um contacto de relação contínua, revelando ainda que os clientes vêem a utilização dos serviços de pós-venda como vantagem competitiva para o presente e futuro das organizações.

Desse modo, ressalta o entendimento que as organizações devem procurar conquistar o cliente de maneira estratégica e eficiente, buscando satisfazê-lo plenamente. Segundo Chiavenato (2014), a satisfação do cliente deve ser total, sendo reforçada antes, durante e após o processo da venda. Com base nos resultados da pesquisa, deduz-se que os clientes dão preferência às empresas que os dão assistência após a compra, reforçando a teoria dos autores pesquisados. Pode-se considerar que o serviço de pós-venda pode influenciar de forma significativa a fidelização dos clientes, sendo a ponte entre o cliente e a organização.

De modo a contribuir com a organização estudada, apresenta-se no final desse trabalho propostas de melhorias, baseando-se nos conceitos dos autores estudados e no conhecimento obtido por meio da análise de dados da pesquisa. 


\section{pontěditora}

Destaca-se que as principais contribuições do estudo consistem em conhecer a perceção dos clientes em relação ao tema da pesquisa e, assim, propor melhorias objetivando o aumento do nível de satisfação dos clientes, o que leva por consequência à sua fidelização e para o meio académico que poderá utilizar o trabalho como fonte de pesquisa e referência. Ressalta-se ainda que, por tratar-se de um estudo de caso, os resultados aqui descritos não devem ser generalizados a outras empresas do mesmo ou de diferentes segmentos.

Diante do exposto, apresenta-se a seguir as propostas recomendadas à empresa, considerando os resultados mais relevantes para esse trabalho.

\section{Quadro 1 - Recomendações}

\section{Recomendações}

\begin{tabular}{|c|l|}
\hline \hline Treinamento & $\begin{array}{l}\text { Executar treinamento à força de vendas, } \\
\text { para melhor capacitação de toda a equipa, } \\
\text { sendo de suma importância que os } \\
\text { vendedores tenham em vista a importância } \\
\text { de se prestar o serviço de pós-venda e } \\
\text { conheçam os objetivos estratégicos da } \\
\text { organização. }\end{array}$ \\
\hline Banco de dados & $\begin{array}{l}\text { Organizar o banco de dados de todos os } \\
\text { clientes ativos na empresa e, se possível, } \\
\text { resgatar os dados dos clientes inativos. É } \\
\text { importante enfatizar que, para empregar o } \\
\text { serviço de pós-venda, a empresa organize } \\
\text { o banco de dados de seus clientes da forma } \\
\text { mais legítima possível, para que, assim, } \\
\text { conheça os seus clientes de maneira mais } \\
\text { individual, de modo a estreitar o } \\
\text { relacionamento, mantendo-se ativa na } \\
\text { mente do consumidor. }\end{array}$ \\
\hline
\end{tabular}




\section{pontěditora}

\begin{tabular}{|c|l|}
\hline Estruturar ações & $\begin{array}{l}\text { Propõe-se verificar periodicamente o } \\
\text { banco de dados de todos os clientes, } \\
\text { utilizando-se desta informação, } \\
\text { sustentação para o contacto com o mesmo. }\end{array}$ \\
\hline Documentar ações & $\begin{array}{l}\text { Deve-se documentar cada ação ocorrida, } \\
\text { assim como utilizar-se destes resultados, } \\
\text { permitindo identificar os desejos dos } \\
\text { clientes e apresentar o que de facto } \\
\text { responderá à sua necessidade. }\end{array}$ \\
\hline
\end{tabular}

Fonte: Dados da pesquisa (2017).

\section{REFERÊNCIAS}

BARRETO Iná Futino; CRESCITELLI Edson. Marketing de relacionamento: como implantar e avaliar resultados. São Paulo: Pearson Education do Brasil, 2013.

CHIAVENATO, Idalberto. Gestão de vendas: uma abordagem introdutória: transformando um profissional de vendas em um gestor de vendas. Barueri, SP: Manole, 2014.

CHURCHILL, Jr. Gilbert A.; PETER J. Paul. Marketing: criando valor para os clientes. São Paulo: Saraiva, 2012.

FUTRELL Charles M. Vendas: fundamentos e novas práticas de gestão. São Paulo: Saraiva, 2003.

GARCIA Janaína Leonardo. Marketing de serviços e de varejo. São Paulo: Pearson Education do Brasil, 2015.

GIL, Antônio Carlos. Como elaborar projetos de pesquisa. São Paulo: Atlas, 2009.

KAUARK Fabiana da S.; MANHÃES Fernanda C; MEDEIROS Carlos $\mathrm{H}$. Metodologia depesquisa: um guia prático. Itabuna/Ba : Via Litteraraum, 2010.

KOTLER, Philip. Administração de marketing: análise, planejamento,implementação e controle. São Paulo: Atlas, 1998.

KOTLER Philip. Marketing essencial: conceitos, estratégias e casos. São Paulo: Prentice Hall, 2005.

KOTLER Philip; ARMSTRONG Gary. Princípios de marketing. São Paulo: Pearson

$\mathrm{e}^{3}$ - Revista de Economia, Empresas e Empreendedores na CPLP | Volume 4 | Número 1 
Education do Brasil, 2015.

KOTLER Philip; KELLER Kevin Lane. Administração de marketing: a bíblia do marketing. São Paulo: Pearson Prentice Hall, 2006.

MARCONI, Marina de Andrade; LAKATOS, Eva Maria. Fundamentos de metodologia científica. São Paulo: Atlas, 2005.

MARCONI, Marina de Andrade; LAKATOS, Eva Maria. Técnicas de pesquisa: planejamento e execução de pesquisa; Amostragens de técnicas de pesquisa; elaboração, análise e interpretação de dados. São Paulo: Atlas, 2002.

SAMARA Beatriz Santos; BARROS José Carlos de. Pesquisa de marketing: conceitos e metodologia. São Paulo: Pearson Prentice Hall, 2006.

SAMARA Beatriz Santos; MORSCH Marco Aurélio. Comportamento do consumidor: conceitos e casos. São Paulo: Prentice Hall, 2005.

VERGARA, Sylvia Constant. Métodos de pesquisa em administração. São Paulo: Atlas, 2008.

VERGARA, Sylvia Constant. Projetos e relatórios de pesquisa em administração. Rio de Janeiro: Atlas, 2000.

\section{(c) BY-NC-SA}

O trabalho $\mathrm{e}^{3}$ - Revista de Economia, Empresas e Empreendedores na CPLP está licenciado com uma Licença Creative Commons - Atribuição-NãoComercial-Compartilha Igual 4.0 Internacional. 